\title{
Pteridófitas da vegetação nativa do Jardim Botânico Municipal de Bauru, Estado de São Paulo, Brasil
}

\author{
Giseli Areias Nóbrega ${ }^{1,2}$ e Jefferson Prado ${ }^{1}$
}

Recebido: 28.06.2007; aceito: 21.02.2008

\begin{abstract}
Pteridophytes of the native vegetation of Jardim Botânico Municipal de Bauru, São Paulo State, Brazil). In this paper we present a floristic survey of the pteridophytes from the native vegetation of the Jardim Botânico Municipal de Bauru (JBMB), Bauru, São Paulo State, Brazil. The JBMB is located in the central region of the State, it has an area of 321.71 ha and the principal vegetation kinds are savanna ("Cerrado"), remnants of "Floresta Estacional Semidecidual Aluvial", and "Floresta Estacional Semidecidual Submontana". The material was collected according to the usual techniques for vascular plants and deposited in the Herbaria JBMB, UNBA, and SP. The data showed the occurrence of 54 taxa, distributed in 28 genera, 49 species, one subspecies, and four varieties. The most representative genera are: Thelypteris (11 species) and Blechnum (four species). Polybotrya goyazensis Brade and Thelypteris biformata (Rosenst.) R.M. Tryon are new citations to São Paulo State. Thelypteris eriosora (Fée) Ponce was recorded for the first time to the central region of the State in low elevations.
\end{abstract}

Key words: cerrado, ferns, floristic, lycophytes

RESUMO - (Pteridófitas da vegetação nativa do Jardim Botânico Municipal de Bauru, Estado de São Paulo, Brasil). O objetivo deste trabalho foi o levantamento florístico das pteridófitas presentes na área de vegetação nativa do Jardim Botânico Municipal de Bauru (JBMB), Bauru, Estado de São Paulo, Brasil. O JBMB localiza-se na região centro-oeste do Estado, possui 321,71 hectares e a vegetação é constituída de Savana (Cerrado), remanescentes de Floresta Estacional Semidecidual Aluvial e Floresta Estacional Semidecidual Submontana. Os espécimes foram coletados de acordo com as técnicas usuais para plantas vasculares e depositados nos Herbários JBMB, SP e UNBA. Os dados demonstram a ocorrência de 54 táxons, distribuídos em 28 gêneros, 49 espécies, uma subespécie e quatro variedades. O gênero com maior número de representantes foi Thelypteris, com 11 espécies, seguido de Blechnum, com quatro espécies. Polybotrya goyazensis Brade e Thelypteris biformata (Rosenst.) R.M. Tryon são novas citações para o Estado de São Paulo. Thelypteris eriosora (Fée) Ponce foi relatada pela primeira vez para a região, ocorrendo em baixas altitudes.

Palavras-chave: cerrado, florística, licófitas, samambaias

\section{Introdução}

O grupo das pteridófitas, quando considerado como uma Divisão única, compreende um táxon artificial. Essas plantas, conforme Pryer et al. (2004), poderiam ser divididas em dois grupos distintos: Lycophyta e Monilophyta. Entretanto, Smith et al. (2006) esclarecem que os nomes aplicados às Monilophyta ou Infradivisão Moniliformopses não são categorias taxonômicas validamente publicadas, carecendo de diagnose ou descrição em latim. Desta forma, ainda é necessária a elaboração de nomes adequados para designar esses grupos.

As Lycophyta, segundo Smith et al. (2006), representam menos de $1 \%$ das plantas vasculares existentes, enquanto as Monilophyta (sensu Pryer et al. 2004), incluindo Equisetum, Psilotum e todas as samambaias eusporangiadas e leptosporangiadas, apresentam cerca de 9.000 espécies e representam aproximadamente $3,6 \%$ do total de plantas vasculares.

No Brasil estima-se que ocorram cerca de 1.200-1.300 espécies de pteridófitas e cerca de 400-600 destas no Estado de São Paulo (Prado 1998). A maioria das espécies do Estado encontra-se na Mata Atlântica e nas matas das regiões serranas da porção leste (Serra da Mantiqueira, Serra da Bocaina, área do Vale do Ribeira e Serra do Japi), uma porcentagem menor ocorre nas regiões serranas da porção central (região de São Carlos e Analândia) e no interior

1. Instituto de Botânica, Caixa Postal 3005, 01061-970 São Paulo, SP, Brasil

2. Autor para correspondência: giareias@gmail.com 
do Estado. Ainda uma quantidade significativa de espécies ocorre em matas de galeria, remanescentes de matas mesófilas, matas secas semidecíduas e Cerrados (Prado 1998).

Trabalhos envolvendo levantamentos florísticos de pteridófitas no interior do Estado de São Paulo são escassos, destacam-se os de Windisch (1990), Simabukuro et al. (1994), Salino (1996, 2002, 2004a, b), Siqueira \& Windisch (1998), Hirai \& Prado (2000) e Colli et al. (2003).

Para a região Centro-Oeste do Estado de São Paulo, onde se localiza o Jardim Botânico Municipal de Bauru (JBMB), este constitui o primeiro trabalho de levantamento para o grupo das pteridófitas. A área do JBMB abriga diferentes tipos de formações vegetais, classificadas segundo Veloso et al. (1991), como Savana (Cerrado), Floresta Estacional Semidecidual Aluvial e Floresta Estacional Semidecidual Submontana. Dentre essas formações vegetais a Floresta Estacional Semidecidual Aluvial (mata de brejo) registra alta diversidade florística, reflexo da heterogeneidade de condições ecológicas desse ambiente (Rodrigues \& Leitão Filho 2000).

O presente estudo teve como objetivo o levantamento florístico das pteridófitas presentes nesses diferentes tipos de vegetação nativa encontrados na área do Jardim Botânico Municipal de Bauru.

\section{Material e métodos}

A área do Jardim Botânico Municipal de Bauru (JBMB) está localizada na região centro-oeste do Estado de São Paulo, na região sudeste da cidade de Bauru. Possui área de 321,71 ha e altitudes entre 510 e $540 \mathrm{~m}$ (Pinheiro et al. 2002). O clima da região, conforme a classificação de Koeppen (1948) é Cwa. O solo é do tipo Latossolo Vermelho-Escuro Fase Arenosa (Comissão de Solo 1960) e a área é drenada pelo córrego Vargem Limpa (Paschoal \& Corrêa 1996, figura 1).

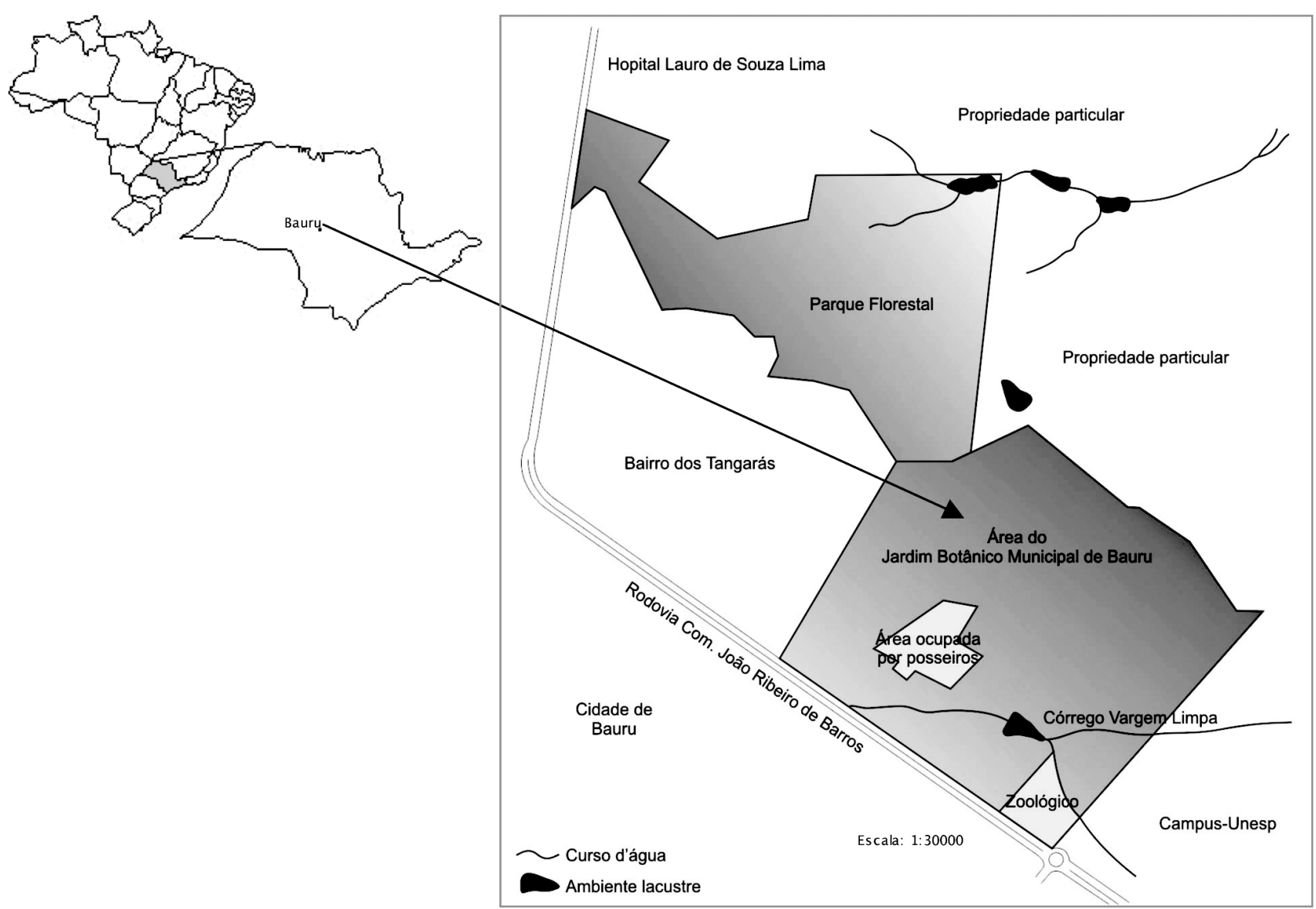

Figura 1. Vista geral do Jardim Botânico Municipal de Bauru e áreas adjacentes (mapa adaptado de Paschoal \& Corrêa 1996). 
De acordo com a classificação de Veloso et al. (1991), a vegetação é composta por Savana (Cerrado), com predomínio de Savana Estacional Florestada, com mata de galeria, remanescentes de Floresta Estacional Semidecidual Aluvial (mata de brejo) e Floresta Estacional Semidecidual Submontana.

Foram realizadas 12 expedições ao Jardim Botânico Municipal de Bauru, no período de janeiro de 2004 a março de 2006. Em média foi efetuada uma expedição de coleta a cada dois meses.

Preparou-se o material coletado de acordo com a metodologia de preservação e herborização padrão indicada por Silva (1989). Os exemplares foram depositados nos herbários do Instituto de Botânica de São Paulo (SP), da Unesp de Bauru (UNBA) e do Jardim Botânico Municipal de Bauru.
Devido às mudanças constantes na circunscrição das famílias em pteridófitas, optou-se por apresentar o presente levantamento florístico ordenado por gênero.

O tratamento taxonômico está apresentado em ordem alfabética e a abreviação dos nomes dos autores dos táxons seguiu Pichi Sermolli (1996).

O item distribuição geográfica foi elaborado de modo a apresentar a ocorrência dos táxons fora e dentro do Brasil. A distribuição, no Brasil, é apresentada de forma abreviada através da sigla dos Estados.

\section{Resultados e Discussão}

Os dados obtidos demonstram a ocorrência de 54 táxons, distribuídos em 27 gêneros, 49 espécies, uma subespécie e quatro variedades (tabela 1).

Tabela 1. Gêneros e espécies de Pteridófitas encontrados na área do Jardim Botânico Municipal de Bauru, São Paulo, Brasil.

\begin{tabular}{|c|c|}
\hline Gêneros & Espécies \\
\hline Adiantopsis Fée & Adiantopsis chlorophylla (Sw.) Fée \\
\hline Adiantum $\mathrm{L}$. & Adiantum serratodentatum Humb. et Bonpl. \\
\hline Anemia $\mathrm{Sw}$. & $\begin{array}{l}\text { Anemia phyllitidis (L.) Sw. } \\
\text { Anemia villosa Humb. \& Bonpl. ex Willd. }\end{array}$ \\
\hline Asplenium L. & Asplenium auritum $\mathrm{Sw}$. \\
\hline Blechnum L. & $\begin{array}{l}\text { Blechnum brasiliense Desv. } \\
\text { Blechnum imperiale (Fée \& Glaziou) Christ } \\
\text { Blechnum occidentale L. } \\
\text { Blechnum regnellianum (Kunze) C. Chr. }\end{array}$ \\
\hline Campyloneurum C. Presl & $\begin{array}{l}\text { Campyloneurum angustifolium (Sw.) Fée } \\
\text { Campyloneurum major (Hieron. ex Hicken) Lellinger }\end{array}$ \\
\hline Cyathea Sm. & $\begin{array}{l}\text { Cyathea atrovirens (Langsd. \& Fisch.) Domin } \\
\text { Cyathea delgadii Sternb. }\end{array}$ \\
\hline Cyclodium C. Presl & Cyclodium meniscioides (Willd.) C. Presl var. meniscioides \\
\hline Dicranopteris Bernh. & Dicranopteris flexuosa (Schrad.) Underw. \\
\hline Doryopteris J. Sm. & $\begin{array}{l}\text { Doryopteris concolor (Langsd. \& Fisch.) Kuhn } \\
\text { Doryopteris lomariacea Klotzsch }\end{array}$ \\
\hline Equisetum L. & Equisetum giganteum $\mathrm{L}$. \\
\hline Lindsaea Dryand. & $\begin{array}{l}\text { Lindsaea divaricata Klotzsch } \\
\text { Lindsaea lancea }(\mathrm{L} .) \text { Bedd. var. lancea } \\
\text { Lindsaea quadrangularis Raddi subsp. quadrangularis }\end{array}$ \\
\hline Lycopodiella Holub & $\begin{array}{l}\text { Lycopodiella alopecuroides (L.) Cranfill var. integerrima (Spring) B. Øllg. \& } \\
\text { P.G Windisch } \\
\text { Lycopodiella camporum B. Øllg. \& P.G. Windisch }\end{array}$ \\
\hline Macrothelypteris (H. Itô) Ching & Macrothelypteris torresiana (Gaud.) Ching \\
\hline Microgramma C. Presl & $\begin{array}{l}\text { Microgramma lindbergii (Mett.) de la Sota } \\
\text { Microgramma squamulosa (Kaulf.) de la Sota }\end{array}$ \\
\hline Nephrolepis Schott & Nephrolepis pectinata (Willd.) Schott \\
\hline Osmunda L. & Osmunda regalis L. var. spectabilis (Willd.) A. Gray \\
\hline Pecluma M.G. Price & Pecluma paradiseae (Langsd. \& Fisch.) M.G. Price \\
\hline Pityrogramma Link & $\begin{array}{l}\text { Pityrogramma calomelanos (L.) Link } \\
\text { Pityrogramma trifoliata (L.) R.M. Tryon }\end{array}$ \\
\hline Pleopeltis Humb. \& Bonpl. & $\begin{array}{l}\text { Pleopeltis astrolepis (Liebm.) E. Fourn. } \\
\text { Pleopeltis pleopeltifolia (Raddi) Alston }\end{array}$ \\
\hline
\end{tabular}


Tabela 1 (continuação)

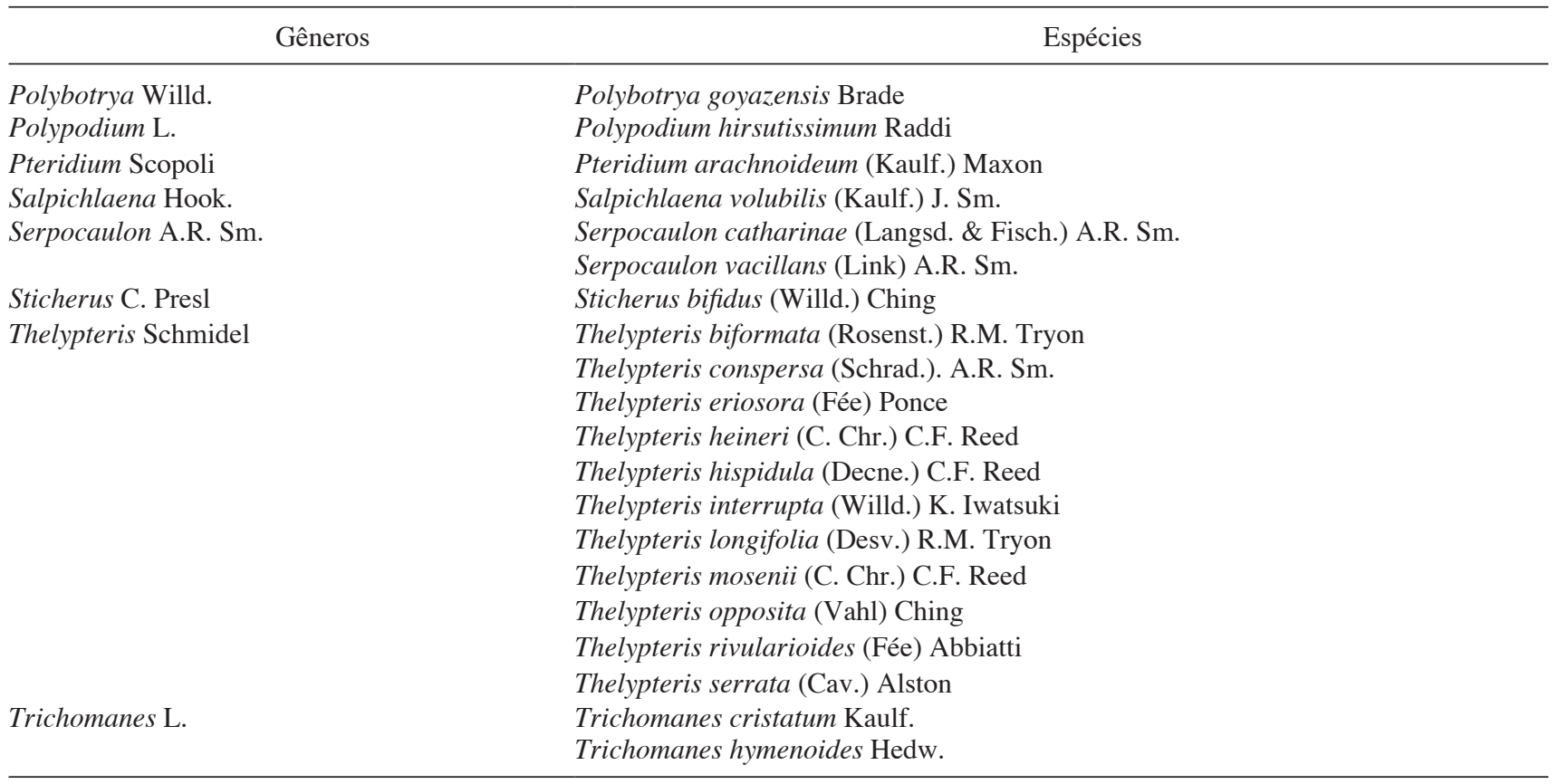

Chave para gêneros de pteridófitas encontrados no Jardim Botânico Municipal de Bauru

1. Lâmina com uma única nervura não ramificada

2. Caule aéreo ereto, articulado, nitidamente dividido em nós e entre-nós; ramos laterais verticilados

. Caule aéreo reptante, não articulado, nós não evidentes; ramos laterais eretos, simples a três vezes furcados

Lycopodiella

1. Lâmina com várias nervuras ramificadas

3. Ânulo apical, oblíquo ou vestigial

4. Lâmina com pinas estéreis e férteis dimorfas

5. Pinas férteis pecioluladas, inseridas na base ou abaixo da base do primeiro par de pinas estéreis

Anemia

5. Pinas férteis não pecioluladas, localizadas apenas na porção distal da lâmina

Osmunda

4. Lâmina com pinas estéreis e férteis monomorfas

6. Plantas arborescentes

Cyathea

6. Plantas herbáceas

7. Lâmina pinatífida ou mais vezes dividida, nunca pseudodicotomicamente; tecido laminar com até duas camadas de células em espessura

Trichomanes

7. Lâmina pseudodicotomicamente dividida; tecido laminar com mais de duas camadas de células em espessura

8. Gemas protegidas por indumento de tricomas; par de pinas acessórias presente na base de cada pseudodicotomia Dicranopteris

8. Gemas protegidas por indumento de escamas; par de pinas acessórias ausente na base de cada peseudodicotomia

Sticherus

3. Ânulo vertical interrompido pelo pedicelo

9. Pecíolo com dois feixes vasculares na base

10. Escamas do caule clatradas; indúsio linear Asplenium

10. Escamas do caule não clatradas; indúsio reniforme a reniforme-arredondado, peltado ou ausente 
11. Lâmina 2-pinada a 2-pinado-pinatífida Macrothelypteris

11. Lâmina 1-pinada a 1-pinado-pinatífida Thelypteris

9. Pecíolo com um, três ou mais feixes vasculares na base

12. Plantas com indúsio verdadeiro ou pseudo-indúsio

13. Soros marginais; pseudo-indúsio formado pela margem da lâmina curvada e modificada

14. Pecíolo amarelo a pardo, não brilhante

Pteridium

14. Pecíolo castanho-escuro a preto, brilhante

15. Pínulas ou últimos segmentos dimidiados; esporângios formados sobre o pseudo-indúsio

Adiantum

15. Pínulas ou últimos segmentos não dimidiados; esporângios inseridos na face abaxial da lâmina

16. Pecíolo com alas estreitas e membranáceas adaxialmente Adiantopsis

16. Pecíolo desprovido de alas adaxialmente Doryopteris

13. Soros abaxiais (marginais em Lindsaea, porém surgindo na superfície abaxial); indúsio verdadeiro

17. Soros arredondados a reniformes; indúsios peltados, reniformes, arredondados, semilunares, peltados ou com um sinus largo ou estreito

18. Pinas contínuas; pecíolo com 8 a 16 feixes vasculares na porção basal .... Cyclodium

18. Pinas articuladas; pecíolo com 3 feixes vasculares na porção basal ..... Nephrolepis

17. Soros lineares contínuos; indúsios lineares

19. Pínulas ou segmentos dimidiados; indúsio abrindo-se em direção à margem Lindsaea

19. Pínulas ou segmentos não dimidiados; indúsio abrindo-se em direção à costa ou cóstula

20. Plantas herbáceas ou subarborescentes; frondes com crescimento determinado

20 Plantas trepadeiras; frondes com crescimento indeterminado ........ Salpichlaena

12. Plantas desprovidas de indúsio

21. Plantas hemiepífitas; soros recobrindo ambas as superfícies da lâmina (anfiacrosticóides)

Polybotrya

21. Plantas terrrestres ou epífitas; soros apenas na superfície abaxial da lâmina

22. Soros lineares dispostos ao longo das nervuras; lâmina com indumento farináceo branco ou amarelo na superfície abaxial

Pityrogramma

22. Soros arredondados a oblongos, dispostos no ápice de uma nervura ou na união de 2-3 nervuras; lâmina desprovida de indumento farináceo

23. Escamas do caule basefixas; lâmina pinatissecta e pectinada; segmentos proximais adnados e reduzidos Pecluma

23. Escamas do caule peltadas; lâmina inteira ou dividida (pinatissecta ou subdicotômica) e não pectinada; segmentos proximais conformes, às vezes deflexos

24. Lâmina densamente ou esparsamente revestida por escamas arredondadas a lanceoladas ou escamas gonfóides

25. Lâmina densamente revestida com escamas gonfóides

Polypodium

25. Lâmina esparsamente revestida com escamas arredondas ou lanceoladas

26. Soros com parafises filamentosas

Microgramma

26. Soros com paráfises escamiformes Pleopeltis

24. Lâmina desprovida de escamas, ou se presentes, inconspícuas, lineares, clatradas e concentradas apenas na costa

27. Lâmina inteira Campyloneurum

27. Lâmina pinatissecta Serpocaulon 
Adiantopsis Fée, Gen. Fil.: 145. 1852. Lectótipo: designado por Christensen, Ind. Fil.: 41. 1906: Adiantum radiatum $\mathrm{L}$. (= Adiantopsis radiata (L.) Fée).

Plantas terrestres ou rupícolas. Caule moderadamente robusto, ereto a decumbente ou horizontal, com escamas e raízes fibrosas. Frondes monomorfas, cespitosas; pecíolo contínuo com o caule, glabro, às vezes escamoso na porção basal, adaxialmente com alas estreitas e membranáceas, com 3 feixes vasculares na base; lâmina pedada, radiada ou 1-4-pinada; raque sulcada adaxialmente, glabra ou pubescente; pinas inteiras ou pinatífidas, contínuas com a raque; pínulas ou segmentos terminais assimétricos; venação aberta. Soros marginais, curtos, arredondados, oblongos, reniformes a lineares; pseudo-indúsio formado pela margem da lâmina revoluta e modificada, glabro; esporângios formados na superfície abaxial da lâmina, protegidos pelo pseudo-indúsio, ânulo vertical, interrompido pelo pedicelo; esporos aclorofilados, triletes, com superfície equinada.

Adiantopsis é um gênero com cerca de sete espécies que ocorre em regiões de florestas e locais rochosos (Tryon \& Tryon 1982). Sua distribuição é principalmente neotropical, com apenas uma espécie paleotropical (em Madagascar). Distingüe-se por apresentar a raque sulcada adaxialmente, os últimos segmentos assimétricos e os esporos equinados. $\mathrm{Na}$ área do JBMB está representado apenas por Adiantopsis chlorophylla (Sw.) Fée.

Adiantopsis chlorophylla (Sw.) Fée, Mém. Foug. 5: 145. 1852 =Cheilanthes chlorophylla Sw., Kongl. Vetensk. Acad. Nya Handl. 1817(1): 76. 1817. Tipo: BRASIL. Sem localidade, s.d., Freyris s.n. (holótipo S, n.v.).

Figura 2 A-B

Plantas terrestres. Caule curto-reptante, ca. $0,9 \mathrm{~cm}$ diâm., com escamas linear-lanceoladas, ferrugíneas, ca. $6 \mathrm{~mm}$ compr. Frondes fasciculadas, $49-78 \mathrm{~cm}$ compr.; pecíolo castanho-escuro, brilhante, 16-42 $\times 0,1-0,2 \mathrm{~cm}$, com escamas na base semelhantes às do rizoma, adaxialmente alado, ao menos na porção superior; lâmina 2-pinado-pinatissecta, deltóide a oval, herbácea a cartácea, glabra, 33-36 × 7-14 cm; raque, costa e cóstula adaxialmente com 2 alas estreitas; pinas 18-23 pares, deltóides a lanceoladas, base truncada, ápice agudo, 5-10 × 1-2 cm; pínulas 14-17 pares, sésseis a curto-pecioluladas, deltóides, 0,4-1 $\times 0,2 \mathrm{~cm}$; segmentos terminais lobados, oblongos a lanceolados, margens revolutas; nervuras simples a 1-furcadas. Soros reniformes; indúsios discretos, verdes a castanho-claros, ca. 0,5 mm larg.

Material examinado: entrada à esquerda do córrego Vargem Limpa, antes da ponte da Trilha de Visitação, 10-III-2004, G.A. Nóbrega et al. 56 (UNBA); área dos posseiros, próximo à cerca da primeira chácara, na borda do brejo ou "Paliteiro", 4-X-2005, G.A. Nóbrega \& M. Andrade 109 (SP).

Distribuição geográfica: México, Guatemala, Costa Rica, Equador, Peru, Bolívia, Paraguai, Argentina e Brasil (DF, MG, RJ, SP, PR, SC, RS).

De acordo com Tryon \& Tryon (1982), esta espécie é freqüentemente encontrada em matas de galeria e florestas abertas. Na área de estudo a espécie cresce em meio a gramíneas na borda da Floresta Estacional Semidecidual Aluvial. Pode ser diferenciada pela forma da lâmina oval a deltóide, com divisão 2-pinado-pinatissecta.

Adiantum L. Sp. Pl. 2: 1094. 1735. Lectótipo: designado por J. Smith, Hist. Fil: 274. 1875: Adiantum capillus-veneris L.

Plantas terrestres ou rupícolas. Caule robusto ou delgado, curto a longo-reptante, raramente subereto, com escamas. Frondes monomorfas a levemente dimorfas, cespitosas ou fasciculadas, eretas a patentes; pecíolo contínuo com o caule, glabro ou pubescente, cilíndrico, brilhante, com 1, 3 ou mais feixes vasculares na base; lâmina 1-5-pinada, deltóide a helicoidal, glabra ou pubescente; pinas dimidiadas ou não, articuladas ou contínuas com a raque; segmentos terminais sésseis a peciolulados, nunca adnados; venação aberta ou areolada, sem vênulas livres inclusas nas aréolas. Soros marginais, curtos, oblongos, reniformes ou lineares; pseudoindúsio formado pela margem da lâmina recurvada e modificada, com nervuras, glabro ou pubescente; esporângios formados sobre a margem recurvada e modificada, com ânulo vertical, interrompido pelo pedicelo; esporos aclorofilados, triletes, superfície usualmente fragmentada formando grânulos ou um estrato levemente papiloso.

Adiantum é um gênero amplamente distribuído nas regiões tropicais, com cerca de 200 espécies neotropicais, das quais 65 a 70 encontram-se na América do Sul (Lellinger \& Prado 2001). No Brasil, o gênero está representado por cerca de 59 espécies, a maioria ocorrendo em florestas primárias e 


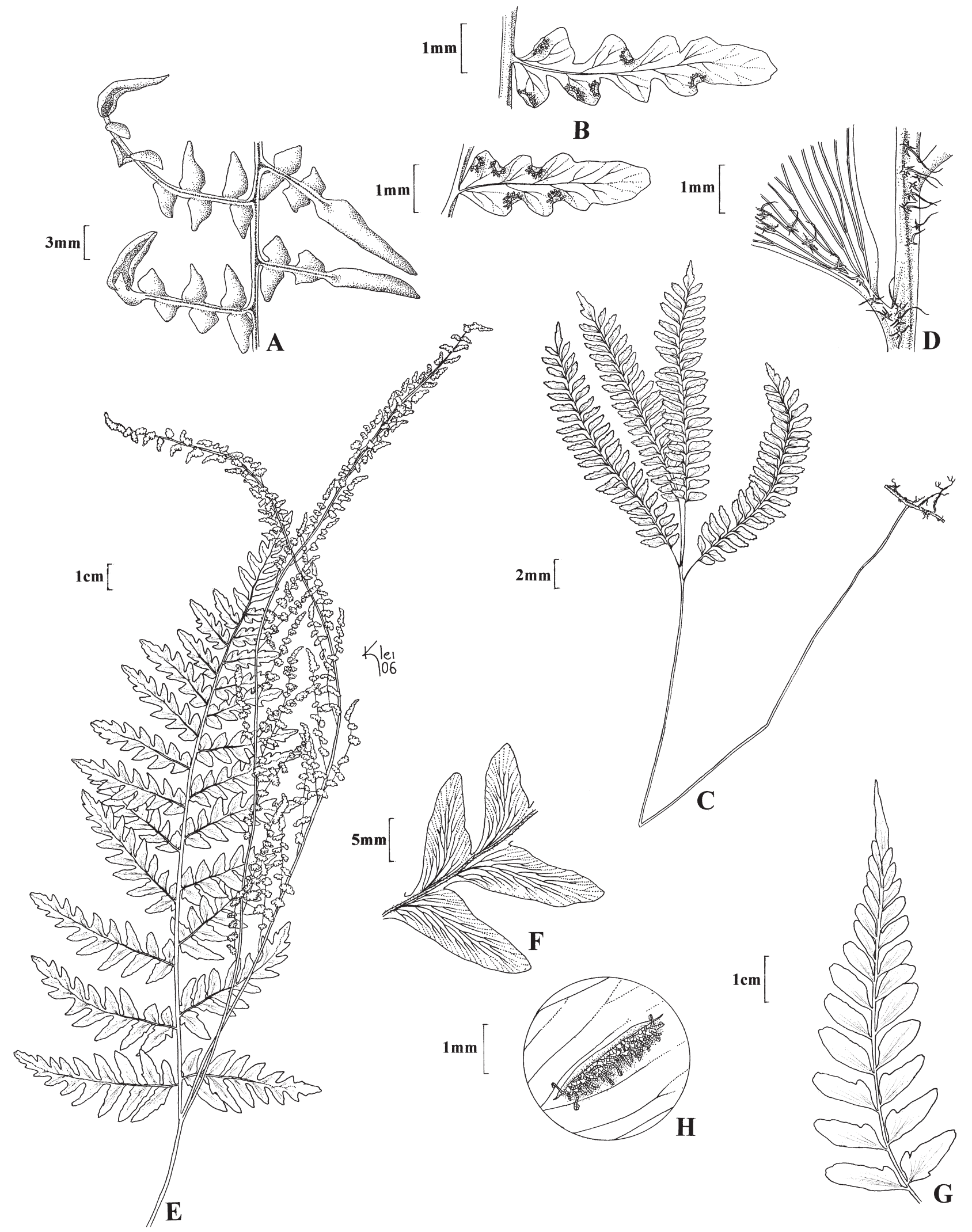

Figura 2. A-B. Adiantopsis chlorophylla. A. Pínulas. B. Detalhe das pínulas férteis. C-D. Adiantum serratodentatum. C. Hábito. D. Detalhe das escamas sobre a raquíola. E-F. Anemia villosa. E. Parte de uma fronde fértil. F. Detalhe da venação. G-H. Asplenium auritum. G. Pina. H. Detalhe do soro. 
secundárias da região sudeste do país, desde o nível do mar até $2.000 \mathrm{~m}$ de altitude (Prado 2003). De acordo com Prado (2004a), o gênero pode ser caracterizado pelos esporângios formados sobre o pseudo-indúsio e este com nervuras.

Adiantum serratodentatum Humb. \& Bonpl. ex Willd., Sp. Pl. 5: 445. 1810. Tipo: VENEZUELA. Sem localidade, s.d., Humboldt \& Bonpland 450 (holótipo B-W-20088, n.v., fotos SP!).

Figura 2 C-D

Plantas terrestres. Caule longo-reptante, ca. 1-2 mm diâm, com escamas lanceoladas, castanhoescuras, clatradas, margens inteiras ou levemente denticuladas, 2-3 mm compr. Frondes subdimorfas, 0,33-1,1 m compr. (as férteis com pínulas menores); pecíolo castanho-escuro a negro, brilhante, 20-70 $\times$ $0,1-0,2 \mathrm{~cm}$, com escamas castanho-claras, ramificadas ou pectinadas, tortuosas, filiformes, adpresas; lâmina oblonga, 2-pinada, com escamas pectinadas esparsas na superfície abaxial, com bandas de idioblastos em ambas as superfícies; raque densamente escamosa, com escamas pectinadas, castanho-claras; pinas 4-13 pares, lanceoladas a elípticas, 8-17 cm compr.; pínulas oblongas, dimidiadas, curto-pecioluladas, base cuneada, ápice arredondado, 0,4-1,5 × 0,2-0,5 cm, diminuindo gradualmente em direção ao ápice da pina, margens das pínulas estéreis serreadas na porção distal e acroscópica, inteira na porção basiscópica; segmento terminal não conforme, estreitado, truncado, lobado ou inciso na margem acroscópica, ápice atenuado, 0,6-2 cm compr.; nervuras simples ou furcadas. Soros 6-8 por pínula, oblongos a ovais, sobre as margens distal e acroscópica das pínulas; pseudo-indúsios glabros.

Material examinado: marco 05 da Trilha de Visitação, 30-I-2004, G.A. Nóbrega et al. 2 (UNBA); próximo à lagoa, 30-I-2004, G.A. Nóbrega et al. 16 (UNBA), 19 (UNBA); entre os marcos 89 e 90 da Trilha de Visitação, 4-III-2004, G.A. Nóbrega et al. 46 (SP); entrada à esquerda do córrego, antes da ponte da Trilha de Visitação, na borda do Cerrado, 10-III-2004, G.A. Nóbrega et al. 59 (SP); lado direito do brejo "Paliteiro", 5-XI-2004, G.A. Nóbrega \& M. Andrade 86 (SP), 89 (SP); mata de brejo junto ao Córrego Vargem Limpa “Paliteiro", 22²0'29”S, 4900'90”W, 30-III-2006, J. Prado et al. 1640 (SP).

Distribuição geográfica: México, Costa Rica, Panamá, Colômbia, Venezuela, Guiana, Suriname, Guiana Francesa, Equador, Peru, Bolívia, Trinidad e Brasil (AM, AL, BA, GO, MT, MG, RJ, SP, PR, SC).
Distingüe-se pelo caule longo-reptante, pela lâmina com escamas pectinadas na superfície abaxial, pelas bandas de idioblastos em ambas as faces das pínulas e pela raque densamente coberta por escamas pectinadas. Esta espécie pode ser encontrada em todas as formações vegetais presentes na área de estudo, principalmente na Floresta Estacional Semidecidual Submontana e na Floresta Estacional Semidecidual Aluvial (Mata de Brejo).

Anemia Sw., Syn. fil. 6: 155. 1806. Tipo: Osmunda phyllitidis L. (= Anemia phyllitidis (L.) Sw.)

Plantas terrestres ou rupícolas. Caule longoreptante, horizontal ou decumbente, com tricomas pluricelulares curtos a longos. Frondes subdimorfas a completamente dimorfas, as dimorfas com pinas férteis modificadas, pecioluladas, freqüentemente eretas, com tecido laminar muito reduzido ou ausente, inseridas na base ou abaixo da base da lâmina estéril; pecíolo geralmente sulcado na superfície adaxial; lâmina estéril oval a deltóide, pinatífida a 3-pinada, às vezes apenas pinatilobada, muito raramente simples, ápice pinatífido ou menos frequente com uma pina terminal; costa não ou apenas levemente sulcada adaxialmente; venação aberta ou areolada, sem vênulas livres inclusas nas aréolas; esporângios sésseis, subglobosos ou ovais, com ânulo apical, dispostos em duas fileiras sobre o último segmento das pinas férteis; esporos triletes com sulcos paralelos e proeminentes, equinados, rugoso-reticulados ou com espículas.

Este gênero pode ser encontrado em toda a região Neotropical, sul da Índia, África e Madagascar, crescendo freqüentemente em hábitats perturbados, locais rochosos, semi-áridos ou secos (Øllgaard 2001). Segundo Moran \& Mickel (1995) há ca. de 100 espécies de Anemia, das quais 70 ocorrem no Brasil. De acordo com Mickel (1962), a frequente hibridação encontrada em Anemia pode estar relacionada, em parte, à tendência das espécies crescerem juntas em alguns hábitats. $\mathrm{O}$ gênero distingüe-se pelas frondes 1-3-pinadas, ovais a deltóides, pelos esporângios sobre as pinas eretas, pecioluladas e modificadas.

Chave para as espécies de Anemia

1. Lâmina estéril deltóide a oblonga, 1-pinada; venação areolada ................................................ A. phyllitidis

1. Lâmina estéril oval a lanceolada, 1-pinado-pinatissecta; venação aberta A. villosa 
Anemia phyllitidis (L.) Sw., Syn. Fil.: 155. 1806 = Osmunda phyllitidis L., Sp. Pl.: 1064. 1753. Lectótipo: designado por Proctor, Ferns Jam.: 77. 1985: Plumier, Traité Foug. Amer. tab. 156. 1705, baseada em uma planta de Hispaniola.

Plantas terrestres. Caule ereto, com tricomas aciculares, castanho-avermelhados, 2-6 mm compr. Frondes 47-67 cm compr.; pecíolo sulcado adaxialmente, com tricomas similares aos do caule; lâmina estéril $21-13 \times 12-18 \mathrm{~cm}$, deltóide a oblonga, 1-pinada, pina terminal conforme, com tricomas sobre as nervuras medianas, castanho-avermelhados, aciculares, ca. $1 \mathrm{~mm}$ compr; pinas estéreis inteiras, lanceoladas, arredondadas na base, margens serreadas, ápice acuminado, 4-5 pares, 8-11 cm compr.; raque estéril com tricomas semelhantes aos da lâmina, ca. 2 mm compr.; lâmina fértil reduzida; par de pinas férteis 15-22 × 0,5-1 cm, longo-pecioluladas, peciólulo ca. 9-12 cm compr., emergindo da mesma altura do primeiro par de pinas estéreis; segmentos férteis revolutos; venação areolada.

Material examinado: barranco na trilha de acesso à lagoa, 2-VIII-2005, M. Andrade s.n. (SP391815); estrada da Lagoa, 22-XII-2005, G. A. Nóbrega \& M. Andrade 118 (SP).

Distribuição geográfica: Sul do México, Mesoamérica, Grandes Antilhas, Colômbia, Venezuela, Guiana, Suriname, Equador, Peru, Bolívia, Paraguai, Uruguai, Argentina e Brasil (AM, CE, PE, AL, BA, MT, GO, DF, RJ, SP, PR, SC, RS).

Caracteriza-se pelas nervuras anastomosadas e pela pina terminal conforme. Foi encontrada em áreas abertas, crescendo no meio de trilhas e sobre barrancos, principalmente na Floresta Estacional Semidecidual Submontana e na vegetação junto ao córrego Vargem Limpa.

Anemia villosa Humb. \& Bonpl. ex Willd., Sp. Pl., ed. 4, 5(1): 92. 1810. Tipo: "America meridionalis, s.d., Humboldt \& Bonpland s.n." (holótipo B-W 19496; fotos GH, US ex B, n.v.).

Figura 2 E-F

Plantas terrestres. Caule decumbente, com tricomas tortuosos, alaranjados a dourados, ca. $5 \mathrm{~mm}$ compr. Frondes 48-93 cm compr.; pecíolo sulcado adaxialmente, com tricomas aciculares castanho-claros, ca. $1 \mathrm{~mm}$ compr., inseridos no sulco; lâmina estéril 20-24 × 9-12 $\mathrm{cm}$, oval a lanceolada, 1-pinado-pinatissecta, ápice pinatífido, com tricomas aciculares, alvos, densos na superfície abaxial e moderados a densos na superfície adaxial, ca. 0,5 mm compr.; pinas estéreis pinatissectas, lanceoladas, 10-12 pares, 5,5-6,5 cm compr.; raque estéril com escamas aciculares, castanho-claras, em ambas as superfícies, ca. $5 \mathrm{~mm}$ compr., também presentes na costa; segmentos estéreis deltóides, oblongos a lanceolados, margens levemente revolutas; lâmina fértil muito reduzida; par de pinas férteis $30-35 \times 2-3 \mathrm{~cm}$, longopeciolulado, peciólulo 6,5-8 $\mathrm{cm}$ compr., emergindo da mesma altura do primeiro par de pinas estéreis; segmentos férteis revolutos; venação aberta, nervuras simples ou 1-furcadas.

Material examinado: barranco na estrada de acesso à lagoa, 17-V-2004, G.A. Nóbrega \& M. Andrade 65 (UNBA); próximo à torre de alta tensão, divisa com a área da Unesp, 17-V-2004, G.A. Nóbrega \& M. Andrade 71 (UNBA).

Distribuição geográfica: Colômbia, Venezuela, Guiana, Suriname, Guiana Francesa, Equador, Peru e Brasil (CE, PE, BA, MG, ES, RJ, SP, PR, SC).

De acordo com Mickel (1962) Anemia villosa pode ser distingüida pela forma e divisão da lâmina, oval a lanceolada e pinado-pinatífida, porém essas características podem sofrer alterações devido à hibridização. $\mathrm{Na}$ área de estudo não foi encontrada nenhuma das espécies com as quais A. villosa forma híbridos, como também não foi observada nenhuma relação de hibridação desta espécie com A. phyllitidis, a outra espécie do gênero presente na área. Pode ser encontrada crescendo em barrancos, bordas de mata e locais perturbados pela ação do fogo.

Asplenium L., Sp. Pl. 2: 1078. 1753. Lectótipo: designado por J. Smith, Hist. Fil.: 316. 1875: Asplenium marinum $\mathrm{L}$.

Plantas terrestres, epífitas ou rupícolas. Caule curto-reptante, escandente ou ereto, a maioria com escamas clatradas, margem inteira, raramente ciliada ou denteada. Frondes monomorfas ou dimorfas (em A. trichomanes-dentatum L.), estoloníferas ou não, eretas ou pendentes; pecíolo curto ou longo, às vezes alado, escamoso, especialmente na base, raramente piloso, com 2 feixes vasculares na base; lâmina simples ou 1-3-pinada, membranácea a subcoriácea, linear a oval ou subdeltóide, a maioria glabra, poucas espécies com tricomas diminutos; raque glabra, com tricomas septados ou escamosa, ocasionalmente alada, com poucas a muitas pinas; segmento terminal pinatífido ou serreado; venação aberta ou areolada. 
Soros na superfície abaxial da lâmina, sobre o lado acroscópico das nervuras ou, em poucas espécies, também sobre o lado basiscópico (soros diplazióides), oblongos a lineares, ocasionalmente confluentes na maturidade; indúsio linear persistente, inteiro a erodido, freqüentemente estreito, delicado e hialino; esporângios com pedicelos delgados, unisseriados, ânulo vertical interrompido pelo pedicelo; esporos monoletes.

Asplenium é um gênero cosmopolita, com cerca de 700 espécies, sendo a maioria dessas encontradas em regiões tropicais (Mickel \& Smith 2004). De acordo com Adans (1995), este gênero pode ser facilmente distingüido pelos soros geralmente posicionados apenas sobre um lado da nervura, com o indúsio entre as nervuras medianas. Entretanto, poucas espécies possuem soros duplos que podem ser confundidos com Diplazium. Neste caso, as características dos feixes vasculares da base do pecíolo arranjados em forma de cruz, dos esporângios com pedicelos unisseriados e escamas clatradas conspícuas, separam definitivamente os dois gêneros.

Asplenium auritum Sw., J. Bot. (Schrader) 1800 (2): 1801. Tipo: JAMAICA. Sem localidade, s.d., Swartz s.n. (holótipo S, n.v.).

Figura 2 G-H

Plantas epífitas. Caule ereto, delgado, revestido por escamas clatradas, castanho-escuras, linearlanceoladas a deltóides, ca. 3-5 mm compr. Frondes monomorfas, eretas 7-32 × 0,9-4 cm; pecíolo verde nas porções mediana e distal e negro próximo à base, levemente alado, sulcado na face adaxial, 3,5-15,5 $\times$ $0,1 \mathrm{~cm}$, esparsamente revestido por escamas negras, filiformes, fortemente clatradas, ca. 0,5-1 mm compr.; lâmina 1-pinada, oblongo-lanceolada, cartácea, 3-16 cm compr., com escamas semelhantes às do pecíolo; raque verde e alada; pinas 5-13 pares, elípticas, 0,8-2 $\times 0,4-0,6 \mathrm{~cm}$, pecioluladas, freqüentemente com uma aurícula no lado acroscópico, peciólulo curto, ca. $1 \mathrm{~mm}$ compr, margem e ápice serreado-crenulados e pina terminal pinatissecta; nervuras 1-2 vezes furcadas, terminando na margem da lâmina. Soros lineares, 1-2,5 mm compr.; indúsio inteiro, glabro.

Material examinado: área próxima à Reserva Legal da Unesp (brejo da Unesp), 21-VII-2005, G.A. Nóbrega \& M. Andrade 104 (SP); brejo da Unesp, após uma armação de ferro, 4-X-2005, G.A. Nóbrega \& M. Andrade 116 (SP).

Distribuição geográfica: México, Guatemala, Belize, Honduras, Nicarágua, Costa Rica, Panamá,
Jamaica, Colômbia, Venezuela, Trinidad, Guiana, Suriname, Equador, Galapagos, Peru, Bolívia, África, Madagascar e Brasil (BA, MT, DF, MG, ES, RJ, SP, PR, SC, RS).

Morton \& Lellinger (1966) trataram o complexo Asplenium auritum em duas espécies: A. auritum (com 6 variedades) e A. cuspidatum Lam. (com 5 variedades). Asplenium cuspidatum é caracterizada pela lâmina 2-3-pinada, com pínulas alongadas, estreitas, longoacuminadas, cuspidadas e conspicuamente denteadas, enquanto A. auritum apresenta lâmina geralmente 1-pinada, raramente 2-pinada, nesse caso as pínulas são obovadas, obtusas, com margens inteiras ou ligeiramente denteadas.

Blechnum L., Sp. Pl. 2: 1077. 1753. Lectótipo: designado por J. Smith, Hist. Fil.: 300. 1875: Blechnum occidentale L.

Plantas terrestres, rupícolas, raramente epífitas ou hemiepífitas. Caule decumbente, reptante a ereto, ocasionalmente escandente, raramente subarborescente ou arborescente, escamoso. Frondes com crescimento determinado, monomorfas ou dimorfas; pecíolo contínuo com o caule com mais de 3 feixes vasculares na base; lâmina pinatissecta a 1-pinada, raramente simples ou 2-pinadas; raque ereta, pouco flexível; pinas ou segmentos inteiros ou serreadas, nunca lobados; gemas ausentes ou presentes; aeróforos ausentes ou presentes na base das pinas abaxialmente, ou menos frequiente ao longo do pecíolo; venação aberta ou areolada, sem vênula livre inclusa nas areólas. Soros lineares, sobre uma comissura vascular curta ou longa, paralelos à costa ou cóstula das pinas ou pínulas; indúsio de origem abaxial, linear, abrindo-se em diração à costa ou cóstula, inteiro, erodido ou lacerado; esporângios pedicelados com ânulo vertical interrompido pelo pedicelo; esporos aclorofilados, monoletes.

A distribuição do gênero é pantropical, com a maioria das espécies no Hemisfério Sul e apenas uma espécie, Blechnum spicant (L.) Roth, em regiões temperadas do Hemisfério Norte. Apresenta ca. de 200 espécies (Smith 1995). De acordo com Mickel $\&$ Beitel (1988) Blechnum pode ser separado em dois subgêneros, Lomaria Willd., com frondes dimorfas, e Blechnum L., com frondes monomorfas. Contudo, Michel \& Smith (2004) relataram que as espécies dimorfas constituem diferentes grupos, os quais podem ser considerados como gêneros distintos, enquanto as espécies monomorfas parecem claramente aparentadas umas com as outras, com exceção de $B$. serrulatum (Diafnia (C. Presl) J. Sm.). 
Chave para as espécies de Blechnum

1. Frondes monomorfas

2. Caule subarborescente, não estolonífero; pecíolo com escamas negras; pinas proximais muito reduzidas, auriculiformes ....... B. brasiliense

2. Caule não subarborescente, estolonífero; pecíolo com escamas castanho-avermelhadas; pinas proximais não reduzidas ou levemente reduzidas, oblongo-lanceoladas ........ B. occidentale

1. Frondes dimorfas

3. Caule subarborescente; pinas proximais reduzidas, sésseis, margens não cartilaginosas

B. imperiale

3. Caule decumbente; pinas proximais pouco reduzidas, curto-pecioluladas, margens cartilaginosas B. regnellianum

Blechnum brasiliense Desv., Ges. Naturf. Freunde Berlin Mag. Neuesten Entdeck. Gesammten Naturk. 5: 330. 1811. Tipo: BRASIL. Sem localidade, s.d., Dombey s.n. (holótipo P-JU-1390, n.v.).

Plantas terrestres. Caule ereto, subarborescente, não estolonífero, ca. 34-60 cm altura, com escamas castanho-escuras a negras, linear-lanceoladas, inteiras, 1-2 cm compr. Frondes monomorfas, 1,14-1,2 m compr.; pecíolo castanho a negro, 4-11 cm compr., com escamas na porção basal, basefixas, linear-lanceoladas, negras, 1,5-2 cm compr.; lâmina pinatissecta, 1-pinada na porção proximal, glabra, subcoriácea; raque estramínea, glabra, sulcada adaxialmente; pinas proximais reduzidas, inteiras, auriculiformes, obtusas, sésseis; segmentos medianos lanceolados, adnados, margens serreadas, ápice agudo, $17-18 \times 0,8-1 \mathrm{~cm}$; costa adaxialmente sulcada, sulco mais evidente na porção proximal do segmento; venação aberta, nervuras simples ou furcadas. Soros dispostos paralelamente e em ambas as margens da costa; indúsio estreito com as margens laceradas, abrindo-se em direção à costa.

Material examinado: mata de brejo ou (Paliteiro), próximo à lagoa, 30-I-2004, G.A. Nóbrega et al. 14 (UNBA); início da mata de brejo ou Paliteiro, ao lado da lagoa, 21-V-2004, G.A. Nóbrega \& M. Andrade 72 (UNBA).

Distribuição geográfica: Guatemala, Colômbia, Venezuela, Peru, Bolívia, Paraguai, Uruguai, Argentina e Brasil (PE, BA, GO, MS, MG, ES, RJ, $\mathrm{SP}, \mathrm{PR}, \mathrm{SC}, \mathrm{RS}$ ).
Pode ser distingüida pelo hábito cespitoso e subarborescente, pelas frondes monomorfas e pelas bases dos pecíolos providas de escamas longolanceoladas, castanho-escuras a pretas. Cresce geralmente em solos encharcados e em locais parcialmente sombreados (Prado 2004b). Na área do JBMB pode ser encontrada formando grandes populações em ambientes paludosos.

Blechnum imperiale (Fée \& Glaziou) H. Christ in Schwacke, Pl. Nov. Mineiras 2: 27. $1900 \equiv$ Lomaria imperialis Fée \& Glaziou in Fée, Crypt. Vasc. Brés. 1: 21, tab. 7, fig. 1. 1869. Tipo: BRASIL. RIO DE JANEIRO: Serra dos Órgãos, s.d., A. Glaziou 2801 (holótipo P; isótipo RB, n.v.).

Figura 3 A-B

Plantas terrestres. Caule ereto, subarborescente, não estolonífero, ca. $30 \mathrm{~cm}$ altura, revestido no ápice por escamas linear-lanceoladas, bicolores, castanhoescuras no centro e castanho-claras a douradas nas margens, ápice filiforme, ca. $3 \mathrm{~cm}$ compr. Frondes dimorfas; fronde estéril decumbente, 0,65-1 m compr.; pecíolo da fronde estéril sulcado na superfície adaxial, castanho-claro, base castanho-escura, com escamas iguais às do caule, 9,5-11,5×0,3-0,5 cm; lâmina estéril oblongo-elíptica, pinada na base e região mediana, pinatissecta no ápice, coriácea, adaxialmente glabra e abaxialmente com tricomas tortuosos, castanho-claros a alvos, decíduos, sobre a costa e tecido laminar, 1-2 mm compr.; raque adaxialmente sulcada, com escamas linear-lanceoladas a deltóides na base e longamente filiformes no ápice, tortuosas, margens castanho-claras e centros mais escuros, adaxialmente densas e esparsas a ausentes abaxialmente, 4-8 $\mathrm{mm}$ compr.; pinas proximais reduzidas, inteiras, auriculiformes a vestigiais obtusas, sésseis; pinas medianas lanceoladas, sésseis a adnadas, base com uma breve aurícula no lado basiscópico, ápice agudo, margens levemente revolutas e onduladas, 7,5-9,5 $\times$ $1-1,5 \mathrm{~cm}$; costa levemente sulcada na face adaxial, glabra, com escamas lanceoladas, ápice longamente atenuado, margens fimbriadas, castanho-claras, 2-4 mm compr.; pecíolo da fronde fértil sulcado na face adaxial, castanho-claro a castanho-escuro na base com escamas iguais às do caule; lâmina fértil oblongo-elípitica, pinada; pinas proximais reduzidas a vestigiais; demais pinas lineares, 7-8 × 0,1-0,2 cm; raque adaxialmente sulcada, com escamas castanhoclaras, margens fimbriadas e tricomas longos e tortuosos, castanho-claros a alvos em ambas as superfícies; venação aberta, nervuras simples ou 


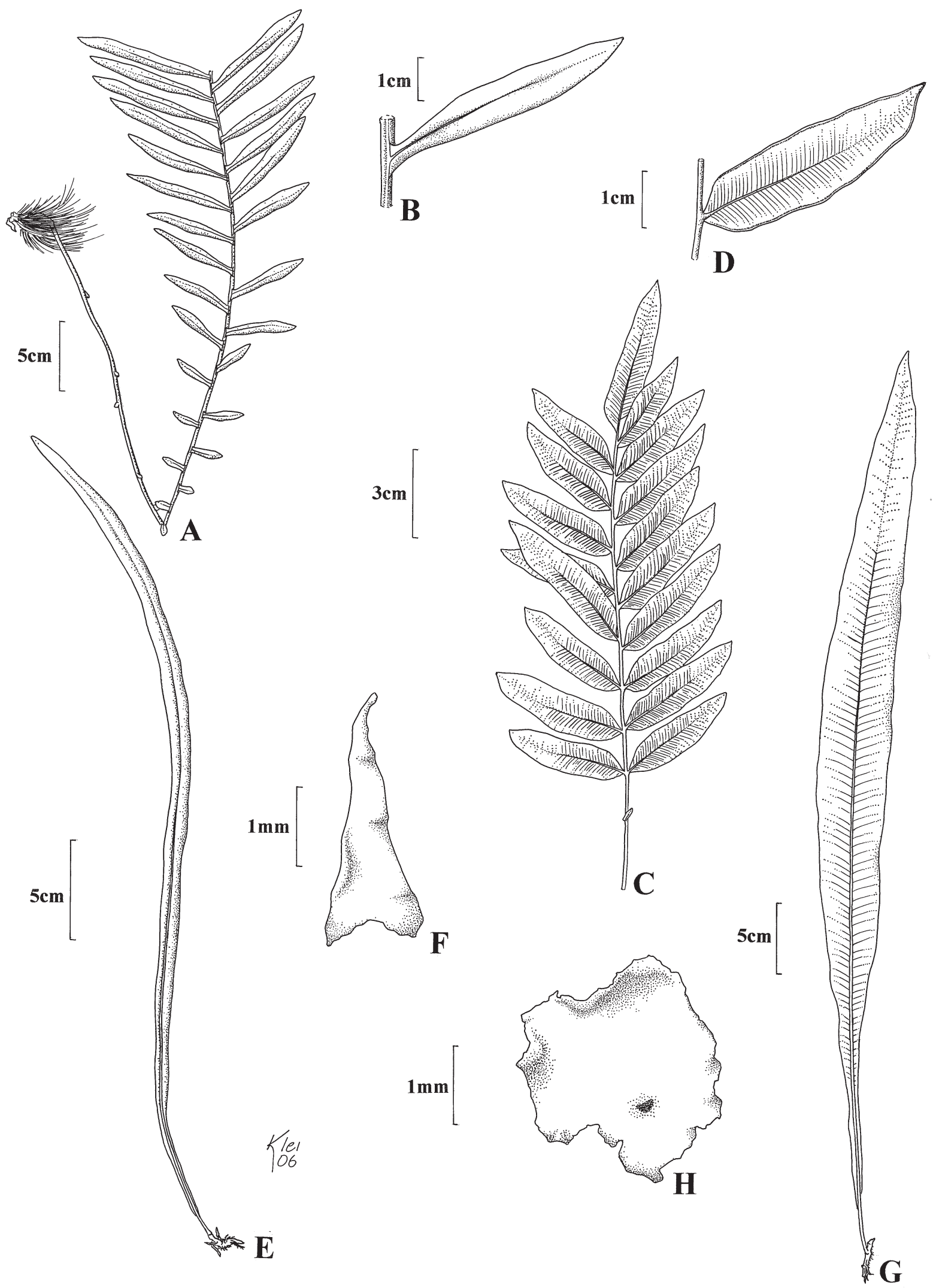

Figura 3. A-B. Blechnum imperiale. A. Porção proximal de uma fronde estéril. B. Pina estéril séssil. C-D. Blechnum regnellianum. C. Parte de uma fronde estéril. D. Detalhe de uma pina estéril com as margens cartilaginosas. E-F. Campyloneurum angustiflolium. E. Fronde estéril. F. Escama do caule. G-H. Campyloneurum major. G. Fronde estéril. H. Escama do caule. 
furcadas. Soros dispostos paralelamente e em ambas as margens da costa; indúsio estreito, com as margens laceradas.

Material examinado: trilha de acesso à lagoa, mata de brejo perto da área invadida, 5-XI-2004, G.A. Nóbrega \& M. Andrade 88 (SP); idem, 9-VI-2005, G.A. Nóbrega \& M. Andrade 101 (SP); idem, 30-III-2006, J. Prado et al. 1650 (SP).

Distribuição geográfica: endêmica do Brasil (MG, RJ, SP, PR, SC, RS).

Pode ser caracterizada no JBMB pelo caule subarborescente com escamas castanhas a douradas, pela lâmina estéril pinada com as pinas proximais muito reduzidas a vestigiais. Foi encontrada apenas em uma localidade, na borda da Floresta Estacional Semidecidual Aluvial, crescendo em local sombreado, sem formar uma grande população.

Blechnum occidentale L. Sp. Pl.: 1077. 1753. Lectótipo: designado por Proctor, Ferns Jam.: 289. 1985: Petivier, Pter. Amer. tab. 3, fig. 9. 1712, baseada em uma planta de Hispaniola.

Plantas terrestres. Caule ereto, estolonífero, ca. 5 mm diâm., com escamas castanho-avermelhadas, centro escuro e margens mais claras, lanceoladas a oblongo-lanceoladas, 6-8 mm compr. Frondes monomorfas, eretas, $46-62 \times 10-13 \mathrm{~cm}$; pecíolo pardo-esverdeado, adaxialmente sulcado, com escamas na base semelhantes às do rizoma, 26-27 $x$ 0,1-0,2 cm; lâmina lanceolada a oblongo-lanceolada, 1-pinada na porção proximal e medial, pinatissecta a pinatífida na porção distal, cartácea a subcoriácea, glabra; raque sulcada adaxialmente, pubescente a glabra, tricomas pluricelulares, tortuosos, ca. $1 \mathrm{~cm}$ compr.; pinas linear-lanceoladas, patentes a voltadas para o ápice da fronde, sésseis ou adnadas, margens inteiras a denticuladas, ápice agudo, 6-7 ×0,8-1 cm, com um par de pinas proximais oblongo-lanceoladas, levemente reduzidas ou não; segmentos na porção distal, adnados, lanceolados, levemente arqueados, margem inteira, ápice agudo; costa sulcada na superfície adaxial; venação aberta, nervuras simples ou furcadas. Soros dispostos paralelamente e em ambas as margens da costa; indúsio com margem inteira a levemente erodida.

Material examinado: começo da trilha de acesso à lagoa, 9-VI-2005, G.A. Nóbrega \& M. Andrade 97 (SP); divisa com a área da Unesp, abaixo dos fios da torre de alta tensão, em área aberta, com solo encharcado, G.A. Nóbrega \& M. Andrade 114 (SP).

Distribuição geográfica: Estados Unidos da América, México, América Central, Antilhas, Colômbia, Venezuela, Guiana, Guiana Francesa, Suriname, Trinidad, Equador, Peru, Bolívia, Paraguai, norte da Argentina e Brasil (CE, PE, AL, BA, MT, GO, MG, ES, RJ, SP, PR, SC, RS).

Esta espécie distingüe-se das demais do gênero que ocorrem no JBMB pelo caule estolonífero, as frondes monomorfas, pinas proximais levemente reduzidas ou não reduzidas e costa das pinas sulcadas adaxialmente (Prado 2004b). Segundo Proctor (1989) uma grande população de híbridos pode ser encontrada em localidades onde ocorrem Blechnum occidentale e Blechnum polypodioides Raddi; esta última não foi registrada para a área, ela diferencia-se da espécie estudada por apresentar muitos pares de pinas proximais gradualmente reduzidos e auriculados na porção mais proximal do pecíolo. Blechnum occidentale pode ser encontrada no JBMB em locais sombreados, na Floresta Estacional Semidecidual Submontana, como também em locais mais abertos, crescendo em meio às gramíneas.

Blechnum regnellianum (Kunze) C. Chr., Index filic.

Suppl.: 17. 1913 = Lomaria regnelliana Kunze, Linnaea 22: 576. 1847. Síntipos: BRASIL. "Ad. Caldas, Minas Gerais, s.d., Regnell 490” (B, n.v.); "Olim ad. Va. Rio das Contas", C.F. Martius s.n. (B, n.v.).

Figura 3 C-D

Plantas terrestres. Caule decumbente a ereto, revestido no ápice por escamas linear-lanceoladas, castanho-claras, basefixas, ca. 0,5-1 ×0,1-0,2 cm. Fondes dimorfas, fronde estéril $50-64 \times 12-14 \mathrm{~cm}$, fronde fértil ereta, 30-59 × 6-8 cm; pecíolo estramíneo, anguloso, sulcado adaxialmente, com escamas semelhantes às do caule na porção basal, 13-41 × 0,2-0,5 cm; lâmina da fronde estéril oblongo-lanceolada, 1-pinada; raque glabra, sulcada adaxialmente; pinas inteiras, distantes, elípticas, ápice agudo, coríaceas, glabras, margem cartilaginosa, ca. 6,5-7 × 1,5-1,7 cm, pinas proximais pouco reduzidas; peciólulo curto ca. $1 \mathrm{~mm}$ compr.; costa abaxialmente com escamas peltadas, alvas a castanhoclaras, linear-lanceoladas a deltóides, ápice longamente acuminado, ca. 4 mm compr.; lâmina fértil oblongolanceolada, 1-pinada; raque sulcada com escamas alvas a castanho-claras, linear-lanceoladas, ápice longamente acuminado, ca. $5 \mathrm{~mm}$ compr.; pinas lineares, voltadas para o ápice da fronde, ápice acuminado, ca. 5-6 × 
0,2-0,3 cm; peciólulo ca. 0,5-1 mm compr.; costa com escamas alvas a castanho-claras, linear-lanceoladas, ápice longamente acuminado, similares às da raque; venação aberta, nervuras simples ou furcadas. Soros recobrindo toda a face abaxial das pinas, exceto no ápice e às vezes na base; indúsio largo ca. 1-1,5 mm larg., lacerado.

Material examinado: trilha da cachoeira, queda d'água do Jardim Botânico (Cachoeirinha), próximo à Reserva Legal da Unesp, 14-IV-2005, G.A. Nóbrega \& M. Andrade 96 (SP).

Distribuição geográfica: endêmica do Brasil (BA, MG, SP, PR, SC, RS).

Esta espécie pode ser caracterizada pelas pinas proximais pouco reduzidas e pelas margens das pinas cartilaginosas. De acordo com Prado \& Labiak (2003), a espécie ocorre em solos arenosos, entre afloramentos rochosos. Na área do JBMB foi encontrada no barranco do Córrego Vargem Limpa, próximo à nascente, em solo conforme o descrito.

Campyloneurum C. Presl, Tent. Pterid.: 189. 1836. Lectótipo: designado por J. Smith., Hist. Fil.: 95. 1875: Campyloneurum repens (Aubl.) C. Presl.

Plantas epífitas, ocasionalmente terrestres ou rupícolas. Caule horizontal, curto a longo-reptante, 1-8 mm diâm, delgado a moderadamente massivo, com raízes fibrosas, escamas peltadas, castanhas, monocromáticas, freqüentemente clatradas, superfície glabra e margem inteira. Frondes monomorfas, agrupadas ou distantes umas das outras, lineares, lanceoladas, oblanceoladas ou elípticas, atenuadas no ápice e base, sésseis a longo-pecioladas, articuladas sobre filopódios pequenos; lâmina inteira, glabra ou pubescente na superfície abaxial, membranácea a coriácea, larga (maior que $6 \mathrm{~cm}$ larg.) ou estreita (menor que $1 \mathrm{~cm}$ larg.), margem inteira, costa às vezes com escamas inconspícuas; venação areolada, com uma ou mais fileiras de aréolas, formadas por nervuras que se anastomosam partindo da nervura principal lateral, duas (ou às vezes mais) nervuras livres excurrentes originando-se do cruzamento das nervuras anastomosantes, em alguns casos há uma terceira nervura excurrente prolongada dividindo a aréola em duas partes. Soros arredondados, no ápice das nervuras inclusas em uma ou mais fileiras entre as nervuras laterais principais; esporângio glabro, com ânulo vertical interrompido pelo pedicelo; esporos aclorofilados, monoletes.
De acordo com Lellinger (1988) e Mickel \& Smith (2004), o gênero abrange 50 espécies neotropicais, sendo mais claramente relacionado com Microgramma C. Presl e Niphidium J. Sm. Campyloneurum pode ser caracterizado pelas frondes geralmente simples, monomorfas, os soros sem paráfises sobre as vênulas livres inclusas nas aréolas e pelas escamas do caule clatradas e glabras (Mickel \& Beitel 1988).

\section{Chave para as espécies de Campyloneurum}

1. Lâmina 0,7-1,3 cm larg., margens cartilaginosas estreitas; escamas do caule linear-lanceoladas, com base levemente auriculada, ca. 2-3 mm compr..... C. angustifolium

1. Lâmina $5-6 \mathrm{~cm}$ larg., margens não cartilaginosas; escamas do caule suborbiculares a ovais, ca. 1-2 mm compr. C. major

Campyloneurum angustifolium ( $\mathrm{Sw}$.) Fée, Mém. Foug. 5: 257. 1852. Tipo: JAMAICA, s.d., Swartz s.n. (holótipo S, foto US, n.v.; isótipos Herb. Willd. 19.611-2, B, foto GH, US, n.v.; BM, foto US, n.v.; Herb. Thunb. 24.458 UPS, n.v.).

Figura 3 E-F

Plantas epífitas. Caule curto-reptante, $2-3 \mathrm{~mm}$ diâm., com escamas linear-lanceoladas, clatradas, castanhas, linear-lanceoladas, com base levemente auriculada, ca. 2-3 mm compr. (tardiamente decíduas e eventualmente deixando partes velhas do caule nuas). Frondes monomorfas, agrupadas, 38-44 cm compr.; pecíolo castanho-claro, ca. $1 \mathrm{~cm}$ compr.; lâmina linearlanceolada, 0,7-1,3 cm larg., glabra, margem inteira, estreitamente cartilaginosa, levemente revoluta, ápice acuminado, base afilada; costa estramínea, levemente sulcada adaxialmente, glabra; nervuras laterais principais imersas e inconspícuas. Soros arredondados em uma ou duas fileiras irregulares entre a margem e a costa.

Material examinado: mata de brejo da Unesp, 21-VII-2005, G.A. Nóbrega \& M. Andrade 107 (SP).

Distribuição geográfica: Estados Unidos da América - Flórida, Grandes Antilhas, Guadalupe, América Tropical do México até a Bolívia e Brasil (PE, BA, MT, GO, MG, RJ, SP, PR, SC, RS).

Campyloneurum angustifolium é uma espécie comum, encontrada sobre rochas, troncos e galhos de árvores, em médias e altas elevações (220-1.300 m) (Mickel \& Beitel 1988). Diferencia-se das demais 
espécies do gênero verificadas no JBMB, pela lâmina estreita (0,7-1,3 cm larg.) com margem cartilaginosa, e pelas escamas do caule linear-lanceoladas com base levemente auriculada. Pode ser encontrada crescendo na Floresta Estacional Semidecidual Aluvial, como epífita.

Campyloneurum major (Hieron. ex Hicken) Lellinger, Amer. Fern J. 78(1): 14. 1988 三 Polypodium phyllitidis L. f. major Hieron. ex Hicken, Rev. Mus. La Plata 15: 272. 1908. Síntipos: ARGENTINA. Pcia. Misiones, Arroyo Nacanguazú, próximo a Puerto Tamaren, 12-II-1883, Niederlein s.n. (B, n.v.); Ruinas para Candelaria, 20-II-1883, Niederlein s.n. (B, n.v.); e "Bei der Plantage El Primer Misionero von Hernandez, Puck and Fernandez", Neiderlein 237 (B, n.v.).

Figura $3 \mathrm{G}-\mathrm{H}$

Plantas terrestres ou epífitas. Caule horizontal, curto a longo-reptante, ca. 5 mm diâm., com escamas castanhas, suborbiculares a ovais, adpressas, ca. 1-2 $\mathrm{mm}$ compr. Frondes monomorfas, $40-80 \mathrm{~cm}$ compr.; pecíolo verde, 4-8 cm compr., fortemente anguloso; lâmina lanceolada a oblanceolada, 5-6 cm larg., glabra, longamente atenuada para a base e para o ápice, margem inteira, cartácea a coriácea; costa estramínea, levemente sulcada adaxialmente, glabra; nervuras partindo da costa formando um ângulo de aproximadamente $75^{\circ} \mathrm{com}$ a mesma, aréolas em 7-8 fileiras entre a costa e a margem da lâmina, com duas vênulas livres inclusas, férteis, por vezes uma terceira vênula estéril cruza a aréola dividindo-a ao meio. Soros arredondados, localizados no ápice das vênulas inclusas, em 7-8 fileiras entre a costa e a margem da lâmina.

Material examinado: mata de brejo (Paliteiro), lado direito do Córrego Vargem Limpa, 26-VI-2004, G.A. Nóbrega \& M. Andrade 83 (UNBA).

Distribuição geográfica: Estados Unidos da América, México, Mesoamérica, Colômbia, Venezuela, Guiana, Suriname, Guiana Francesa, Equador, Peru, Bolívia, Chile, Paraguai, Uruguai, Argentina e Brasil (AM, BA, MG, RJ, SP, PR, SC, RS).

De acordo com Lellinger (1988), Campyloneurum major pode ser caracterizada pelas escamas do caule subadpressas, suborbiculares a amplamente ovais e pelo complexo padrão de venação areolado. Pode ser encontrada na Mata Estacional Semidecidual Aluvial, crescendo como epífita e também como terrestre.
Cyathea Sm., Mém. Acad. Roy. Sci. (Turin) 5: 416. 1793. Tipo: Polypodium arboreum L. (= Cyathea arborea (L.) Sm.).

Plantas terrrestres ou rupícolas. Caule ereto, geralmente massivo, arborescente, até $12 \mathrm{~m}$ de altura. Frondes com até $3 \mathrm{~m}$ compr., monomorfas, raramente subdimorfas, dispostas em forma de coroa no ápice do caule; pecíolo liso a espinhoso, com escamas na base; lâmina 1-pinada a 4-pinado-pinatissecta; pinas e pínulas contínuas com a raque ou raramente articuladas; raque, costa e cóstula adaxialmente e às vezes abaxialmente pilosas; venação aberta ou raramente areolada, com uma única fileira de aréolas. Soros arredondados sobre as nervuras freqüentemente furcadas; indúsio ausente ou presente, globoso, ciatiforme ou escamiforme; esporângios curtopedicelados com ânulo oblíquo não interrompido pelo pedicelo; esporos aclorofilados, triletes.

Cyathea é um gênero Pantropical (mais diversificado no Neotrópico), com ca. de 150 espécies. Pode ser facilmente reconhecido pelo seu porte (até $12 \mathrm{~m}$ de altura), pelas frondes dispostas em forma de coroa no ápice do caule, pelo pecíolo espinhoso e escamoso, com escamas desprovidas de seta apical e pela lâmina geralmente 2-pinado-pinatissecta a 1-4-pinada.

Chave para as espécies de Cyathea

1. Lâmina cartácea; paráfises menores que os esporângios; indúsio inteiro, globoso ....... C. delgadii

1. Lâmina subcoriácea; paráfises mais longas que os esporângios; indúsio ausente ......... C. atrovirens

Cyathea atrovirens (Langsd. \& Fisch.) Domin, Pteridophyta: 262. 1929 ” Polypodium atrovirens Langsd. \& Fisch., Icon. fil.: 12, tab. 14. 1810. Tipo: BRASIL. Santa Catarina: Ilha de Santa Catarina, s.d., Langsdorff s.n. (holótipo LE, n.v.; isótipo BM, n.v.).

Caule ereto, ca. $30-55 \mathrm{~cm}$ altura, com as bases dos pecíolos persistentes formando um ângulo agudo com o caule, com escamas bicromáticas, linearlanceoladas, 15-20 mm compr., desprovidas de setas nigrescentes. Frondes monomorfas, 1,49-3,30 m compr.; pecíolo ca. 1,60 × 0,1 m, com espinhos castanhos a negros, 3-4 mm compr., e escamas semelhantes às do caule; lâmina deltóide, 3-pinadopinatissecta, subcoriácea, gradualmente reduzida em direção ao ápice, com tricomas tortuosos, castanhoclaros, esparsos principalmente sobre as nervuras; 
raque alada, sulcada adaxialmente, com tricomas castanhos na superfície adaxial e escamas castanhas linear-lanceoladas, ápice filiforme, margens ciliadas, basefixas, também presentes na raquíola e costa; pinas 16-17 pares, as laterais lanceoladas e a apical deltóide; pínulas de primeira ordem lanceoladas, 33-43,5 $\times 12-15 \mathrm{~cm}$; pínulas de segunda ordem oblongolanceoladas, crenadas, 6-8 × 1,2-1,5 cm, sésseis a curto-pecioluladas; segmentos levemente arqueados, ápices arredondados, 4-5 mm larg., sinus ca. 4-6 $\mathrm{mm}$ para a costa; segmento terminal não conforme; venação aberta, nervuras predominantemente simples, com poucas bifurcações. Soros inframedianos; paráfises mais longas que os esporângios, indúsio ausente.

Material examinado: área de brejo (Paliteiro) 4-III-2004, G.A. Nóbrega et al. 32 (UNBA); próximo à trilha de acesso à lagoa, ca. $5 \mathrm{~m}$ do Córrego Vargem Limpa, 10-III-2004, G.A. Nóbrega et al. 62 (UNBA); próximo à mata de brejo (Paliteiro), 26-VI-2004, G.A. Nóbrega \& M. Andrade 85 (SP).

Distribuição geográfica: Paraguai, Argentina e Brasil (BA, MG, ES, RJ, SP, PR, SC, RS).

De acordo com Barrington (1978), Cyathea atrovirens cresce em altitudes entre 35 e $900 \mathrm{~m}$ acima do nível do mar, sendo encontrada desde o Estado da Bahia até o Rio Grande do Sul. Difere de Cyathea phalerata (Mart.) Barr., espécie mais semelhante, por esta apresentar nervuras predominantemente furcadas, ocasionalmente livres e estéreis ou com soros posicionados na bifurcação (Barrington 1978). Cyathea atrovirens ainda diferencia-se por apresentar pínulas crenadas (no ápice da lâmina) a pinatífidas, enquanto que $C$. phalerata possui pínulas pinatífidas a pinatissectas (Boldrin \& Prado 2007). Na área pode ser reconhecida por apresentar as partes basais dos pecíolos persistentes, formando um ângulo agudo com o caule, e ainda apresentar paráfises maiores que os esporângios. Foi encontrada na Floresta Estacional Semidecidual Submontana e na Floresta Estacional Semidecidual Aluvial (mata de brejo).

Cyathea delgadii Sternb., Flor. Der Vorwelt 1: 47, tab. B. 1820. Holótipo: BRASIL. GoIÁs: Rancho do Generale Delgado in via ad Caldas Novas, s.d., Pohl s.n. (PRC; fragmento ex PRC, GH, n.v.; fragmento ex L, US é provavelmente da mesma coleção, n.v.).

Caule ereto, ca. $40 \mathrm{~cm}$ compr., com as bases dos pecíolos caducas, com escamas monocromáticas, castanho-claras, lanceoladas, ca. 8-15 mm compr. Frondes monomorfas, $1,14-1,37 \times 0,44-0,56 \mathrm{~m}$ compr.; pecíolo castanho, ca. 50-56 × 0,5 cm, com espinhos castanho-avermelhados, ca. 1-2 mm compr. e escamas densas semelhantes às do caule, com tricomas pluricelulares, castanhos ca. 0,5-1 mm compr.; lâmina deltóide 3-pinado-pinatífida, cartácea, com tricomas densos, ca. 0,5-1 mm compr., castanhos, pluricelulares inseridos nas nervuras; raque com tricomas semelhantes aos da lâmina foliar, e escamas esparsas, castanhas, lanceoladas, ca. 1-5 mm compr., esses indumentos também estão presentes na raquíola e costa; pinas lanceoladas, ápice acuminado, 22-28 cm compr.; pínulas 4-6 $\mathrm{cm}$ compr. sésseis a curto-pecioluladas, oblongo-lanceoladas; segmentos terminais acuminados, ca. 5-6 $\times 2 \mathrm{~mm}$; venação aberta, nervuras simples a 1-furcadas. Soros medianos ou próximos à costa; paráfises menores que os esporângios; indúsio inteiro, globoso, com deiscência irregular.

Material examinado: margem de Córrego Vargem Limpa, próximo da área invadida, 30-III-2006, $J$. Prado et al. 1648, 1649 (SP).

Distribuição geográfica: Costa Rica, Panamá, ao redor da bacia Amazônica desde a Guiana até a Bolívia e Brasil (RR, GO, DF, PI, CE, PE, BA, MT, MS, MG, ES, RJ, SP, PR, SC, RS).

Esta espécie distingue-se facilmente pelas cicatrizes deixadas pelas bases dos pecíolos decíduos, pelo indúsio globoso e pelas escamas castanhas localizadas principalmente na costa e também na raque e raquíola. Possui ampla distribuição, ocorrendo preferencialmente em locais alagados ou úmidos; na área do JBMB foi encontrada na Floresta Estacional Semidecidual Aluvial (mata de brejo), numa depressão.

Cyclodium C. Presl, Tent. Pterid.: 85. 1836. Tipo: Aspidium meniscioides Willd. (= Cyclodium meniscioides (Willd.) C. Presl).

Plantas terrestres ou hemiepífitas. Caule longoreptante, coberto no ápice por escamas geralmente castanhas, lanceoladas ou linear-lanceoladas, margem inteira ou denticulada; pecíolo não articulado com o caule, com 8-16 feixes vasculares na base e estes organizados em círculo. Frondes monomorfas a dimorfas (a fronde fértil em posição mais ereta, com pecíolo mais longo e com segmentos férteis reduzidos), usualmente pinada a 2-pinado-pinatífida, anadrômica 
com o segmento ou pínula sobre o lado acroscópico de uma pina geralmente maior e mais elevada (quando pinada há uma nervura acroscópica lateral mais elevada); lâmina cartácea a coriácea, gradualmente reduzida com um ápice pinatífido ou imparipinada; raque e costa sulcados na superfície adaxial, sulcos mais ou menos confluentes na raque; sulcos e às vezes raque e costa abaxialmente com tricomas uniformemente pequenos; costa na superfície abaxial com escamas reduzidas, unisseriadas, castanhas ou castanhoavermelhadas; pinas contínuas; venação aberta ou venação areolada, freqüentemente com uma vênula inclusa na aréola. Soros abaxiais arredondados; indúsio peltado ou reniforme-arredondado, freqüentemente caduco, glabro ou ciliado-glandular sobre a margem e às vezes sobre a superfície; esporângios longo-pedicelados com ânulo vertical interrompido pelo pedicelo; esporos aclorofilados, monoletes.

De acordo com Smith (1986) há 10 espécies de Cyclodium, sendo a Guiana o centro de diversidade, com seis espécies; Colômbia, Panamá e região oeste da Venezuela, apresentam três espécies; e o Brasil possui duas espécies (C. meniscioides (Willd.) C. Presl e C. heterodon (Schrad.) T. Moore). O gênero ocorre em florestas úmidas da América Tropical, matas de galeria, solos úmidos e brejos, a maioria entre $0 \mathrm{e}$ $800 \mathrm{~m}$ de altitude. Cyclodium está mais relacionado a Polybotrya, diferindo deste pela ausência do hábito hemiepifítico conspícuo, pelo caule desprovido de bainhas de esclerênquima ao redor dos meristelos, pelos soros arredondados, não acrosticóides, com indúsio, e pelos esporos equinados (Smith 1986).

Cyclodium meniscioides (Willd.) C. Presl var. meniscioides, Tent. Pterid: $85.1836 \equiv$ Aspidium meniscioides Willd., Sp. Pl. 5: 218. 1810. Tipo: BRASIL. Sem localidade, s.d., Hoffmannsegg s.n. (B-Hb. Willd. 19737, n.v.).

Figura 4 A-B

Plantas terrestres. Caule curto a longo-reptante, ápice com escamas castanhas, linear-lanceoladas, ca. 7-8 $\times 1-2 \mathrm{~mm}$, margens denticuladas. Frondes 1,3-1,5 m compr., subdimorfas a fortemente dimorfas (frondes férteis com pinas mais estreitas e menores); pecíolo 71-74 × 0,4-0,6 cm, com escamas 7-9 × 1-2 mm; lâmina estéril 1-pinada, com 7-8 pares de pinas laterais e segmento terminal conforme; pinas ovais 20-17 $\times 5-6 \mathrm{~cm}$, margens crenadas ou profundamente serreadas; indumento de escamas esparsas castanhas, aciculares, diminutas, ca. $1 \mathrm{~mm}$ compr., sobre raque, costas, nervuras e lâmina; venação areolada (meniscióide), nervuras laterais principais distantes $4-5 \mathrm{~mm}$, com 4-5 pares de nervuras sinuosas, anastomosadas, ascendendo em direção à margem; lâmina fértil pinada, com 8-9 pares de pinas laterais e um segmento terminal conforme; pina linear-oblonga, menos freqüentemente oval, 10-17 × 2-4 cm, crenada ou serreada; venação similar à fronde estéril com nervuras laterais principais distantes 3-4 mm. Soros arredondados sobre as nervuras sinuosas, freqüentemente confluindo na maturidade, em 4-5 fileiras entre a costa e a margem, bisseriados entre as nervuras principais laterais, com indúsio grande e peltado, ciliado na margem.

Material examinado: mata de brejo (Paliteiro), 21-V-2004, G.A. Nóbrega \& M. Andrade 74 (UNBA); mata de brejo junto ao Córrego Vargem Limpa (Paliteiro), 22²0'29”S, 4900'90"W, 30-III-2006, J. Prado et al. 1642 (SP).

Distribuição geográfica: Trinidad, Guiana, Suriname, Guiana Francesa, Venezuela, Colômbia, Equador, Peru, Bolívia, Argentina, Paraguai e Brasil (AM, AC, AP, PA, PI, CE, BA, GO, DF, MT, MG, SP).

De acordo com Smith (1986), Cyclodium meniscioides ocorre em baixas altitudes $(0-1.150$ $\mathrm{m}$ ), em matas de galeria, ao longo de córregos, em florestas úmidas e brejos. É amplamente distribuída e muito variável, com indivíduos que apresentam desde pequenos até grandes dimorfismos entre as frondes férteis e estéreis. Este dimorfismo acentuado das frondes pode ser facilmente observado nos espécimes da área do JBMB. A espécie caracteriza-se, além das frondes dimorfas, pela venação pouco saliente na superfície adaxial da lâmina e pelas pinas distantes, não sobrepostas (Smith 1986). Foi encontrada em ambiente paludoso, crescendo à sombra, próximo à Blechnum brasiliense.

Dicranopteris Bernh., Neues Jour. Bot. (Schrad.) 1(2): 38. 1806. Lectótipo: designado por Bernhardi, Neues J. Bot. 1(2): 38. 1806: Polypodium dichotomum Thunb. ex Murray (= Dicranopteris dichotoma (Thunb. ex Murray) Bernh.).

Plantas terrestres. Caule delgado, decumbente, longo-reptante, piloso, freqüentemente com tricomas ramificados irregularmente. Frondes monomorfas, escandentes ou eretas, 1-2 vezes ou várias vezes pseudodicotomicamente divididas; pecíolo com tricomas pluricelulares, na região da 


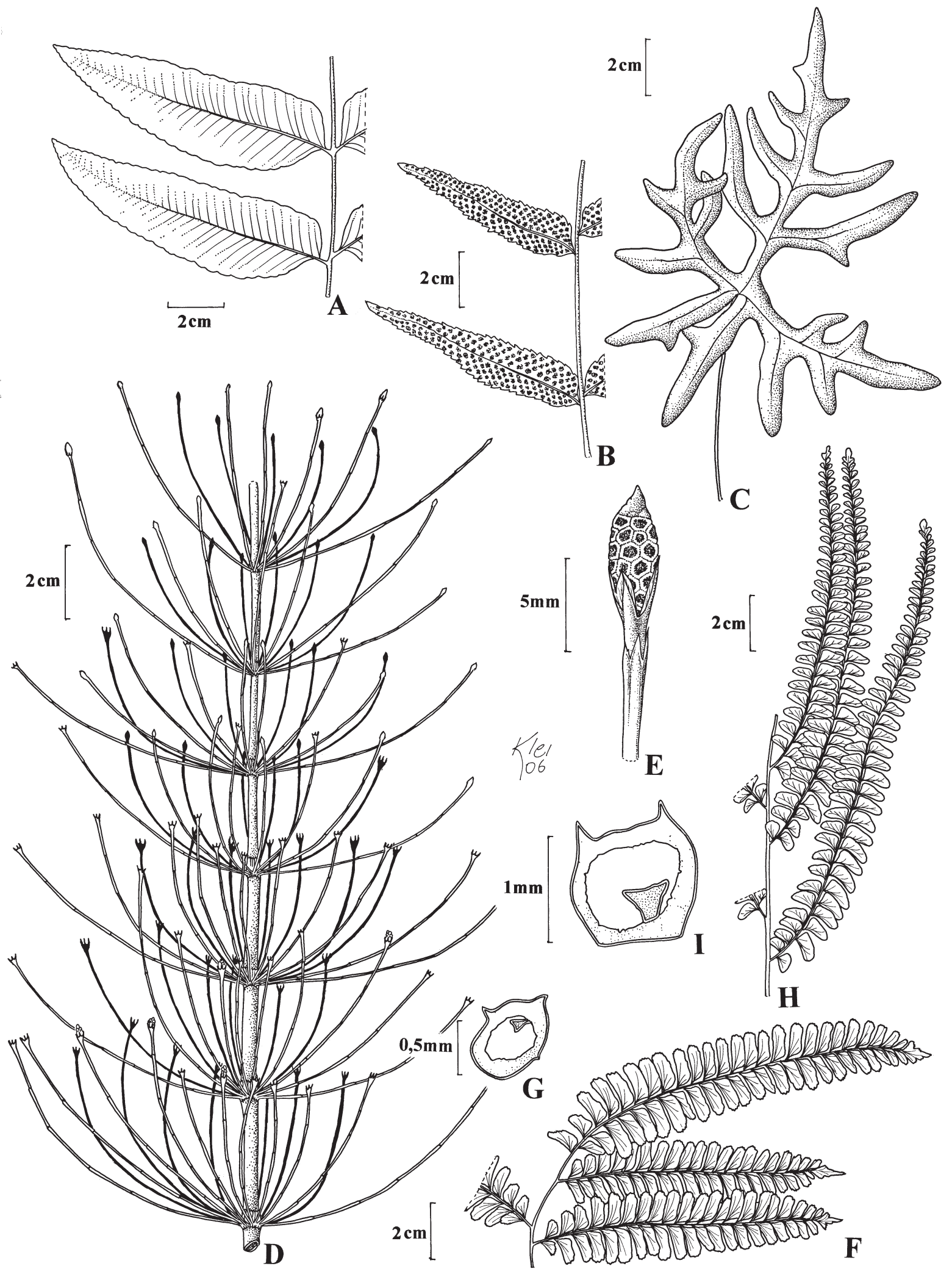

Figura 4. A-B. Cyclodium meniscioides var. meniscioides. A. Pinas estéreis. B. Pinas férteis. C. Doryopteris lomariacea. Parte de uma fronde estéril. D-E. Equisetum giganteum. D. Parte de um ramo aéreo. E. Estróbilo. F-G. Lindsaea divaricata. F. Pinas estéreis. G. Detalhe da raque em corte transversal. H-I. Lindsaea quadrangularis subsp. quadrangularis. H. Pinas estéreis. I. Detalhe da raque em corte transversal. 
pseudodicotomia; ramos primários e secundários da raque não pectinados, ramos terminais pectinados e pinatífidos, glabros ou pilosos; pinas várias vezes furcadas, geralmente com um par de pinas acessórias na base da primeira pseudodicotomia; gemas protegidas por indumento de tricomas pluricelulares e por pseudoestípulas; venação aberta, nervuras 2-3-furcadas. Soros abaxiais arredondados, com 6-15 ou mais esporângios; esporângios com ânulo oblíquo não interrompido pelo pedicelo, com paráfises; esporos aclorofilados, triletes.

Dicranopteris possui 12 espécies, sendo que quatro delas ocorrem na América Tropical (Østergaard-Andersen \& Øllgaard 2001). O gênero pode ser encontrado desde o centro do México até a América Central, nas Antilhas, na América do Sul até o sul da Bolívia, Paraguai, Argentina e Brasil. As espécies crescem em áreas abertas e perturbadas, sendo freqüentemente pioneiras em pastos e clareiras (Tryon \& Tryon 1982). De acordo com Mickel \& Smith (2004), Dicranopteris distingüe-se de Sticherus por este apresentar nervuras simples até uma vez furcada e 2-5 esporângios por soro.

Dicranopteris flexuosa (Schrad.) Underw., Bull. Torrey Bot. Club 34: 254. $1907 \equiv$ Mertensia flexuosa Schrad., Gött. Gel. Anz. 1824: 863. 1824. Tipo: BRASIL. Sem localidade, s.d., Maximilian Prinz Neuwied s.n. (BR, foto BM n.v.).

Plantas terrestres. Caule longo-reptante, 3-2 mm diâm., com tricomas ramificados irregularmente, castanho-avermelhados, ca. 1-2 mm compr. Frondes eretas, ca. $50 \mathrm{~cm}$ compr.; pecíolo castanho-claro, 28-32 $\times 0,15-0,2 \mathrm{~cm}$, com tricomas iguais aos do rizoma na porção basal, glabro distalmente; pinas bifurcadas pseudodicotomicamente, com um par de pinas acessórias na base de cada pseudodicotomia; pseudoestípulas presentes, pinatífidas; gemas protegidas por tricomas pluricelulares, castanho-avermelhados, ca. 1-2 mm compr.; ramos com segmentos pectinados, pinatissectos, $13-15 \times 1,5-2 \mathrm{~cm}$, geralmente mais largos na porção basal; segmentos coriáceos, margens levemente revolutas, 1-1,2 $\times 0,1-0,2 \mathrm{~cm}$, superfície adaxial glabra e superfície abaxial com tricomas diminutos, articulados, castanho-avermelhados; nervuras 2-3-furcadas. Soros medianos, com paráfises castanho-avermelhadas.

Material examinado: área nas proximidades da lagoa, 30-I-2004, G.A. Nóbrega et al. 10 (UNBA); idem, 17-V-2004, G.A. Nóbrega \& M. Andrade 67 (UNBA).
Distribuição geográfica: sudeste dos Estados Unidos da América, sul do México, América Central, Antilhas, Colômbia, Venezuela, Guiana, Suriname, Guiana Francesa, Trinidad, Equador, Peru, Bolívia, Argentina e Brasil (CE, PE, AL, GO, DF, MT, BA, MG, SP, PR, SC, RS). Provavelmente em todos os Estados do país (Windisch 1994).

Caracteriza-se pela fronde com um par de pinas acessórias na base de cada uma das bifurcações, pelos segmentos com as margens levemente revolutas, abaxialmente variando de pilosos a glabros, com tricomas castanho-avermelhados diminutos (Prado \& Labiak 2003, Prado 2004c). Esta espécie foi encontrada em área aberta, próxima à lagoa, crescendo junto com Sticherus bifidus (Willd.) Ching e formando, com esta espécie, grandes comunidades.

Doryopteris J. Sm., J. Bot. (Hooker) 4: 162. 1841. Lectótipo: designado por Morton, Amer. Fern J. 34: 26. 1944: Pteris palmata Willd. (=Doryopteris palmata (Willd.) J. Sm.).

Plantas terrestres ou rupícolas. Caule ereto, subereto a decumbente, pequeno, moderadamente robusto a longo-reptante e delgado, com muitas raízes fibrosas e escamas bicolores, com centro castanho-escuro e margem castanho-clara. Frondes monomorfas a subdimorfas (a fértil mais ereta que a estéril e com segmentos mais estreitos) não articuladas; pecíolo castanho-escuro a preto, brilhante, com 3 ou mais feixes vasculares na base; lâmina com arquitetura diversa, inteira, cordada, sagitada, hastada, 3-lobada ou usualmente pedada, pinatífida a quadripinatífida, às vezes palmada, cartácea a coriácea, glabra; venação aberta ou areolada, sem nervuras livres inclusas nas aréolas, geralmente obscurecidas na lâmina. Soros freqüentemente marginais, contínuos ou interrompidos no sinus, sobre uma comissura vascular; indúsio linear formado pela margem da lâmina curvada e modificada; esporângios com ânulo vertical interrompido pelo pedicelo; esporos triletes.

O gênero possui cerca de 30 espécies em regiões tropicais, rochosas e secas. A maioria delas ocorre no sudeste e no Planalto Central brasileiro. Cinco espécies são endêmicas para Madagascar e uma é pantropical. Doryopteris distingüe-se pelos ramos profundamente lobados e palmados, com soros marginais (Mickel \& Smith 2004).

\section{Chave para as espécies de Doryopteris}

1. Pecíolo cilíndrico com tricomas esparsos; lâmina estéril lobada ............................... D. lomariacea 
1. Pecíolo sulcado ou pouco achatado, desprovido de tricomas; lâmina estéril pedada, pinatissecta, 2-4-pinatífida D. concolor

Doryopteris concolor (Langsd. \& Fisch.) Kuhn in Decken, Resen Ost-Afrika 3(3): 19. $1879 \equiv$ Pteris concolor Langsd. \& Fisch., Pl. voy. Russes monde 19, tab. 21. 1810. Tipo: Pacífico Sul. "Archipelagi Marquesas dicti insula Nucahiva", s.d., Langsdorff s.n. (holótipo LE, n.v.; isótipos BM, B-Willd. 19961, n.v.).

Plantas terrestres. Caule ereto a curto-reptante, com escamas bicolores, linear-lanceoladas, ca. 3 $\mathrm{mm}$ compr. Frondes monomorfas a subdimorfas, 22-48 cm compr.; pecíolo castanho-escuro, ca. $1 \mathrm{~mm}$ diâm., sulcado a levemente achatado adaxialmente, com escamas densas na base e esparsas nas outras porções, semelhantes às do caule; lâmina pedada, pinatissecta, porção basal bipinatífida a quadripinatífida, membranácea a cartácea, margem estéril inteira a irregularmente crenulada, margem fértil extendida para a base do indúsio; nervuras livres. Soro marginal, contínuo, interrompido na região do sinus e no ápice dos segmentos; indúsio com margem inteira, 0,3-0,5 mm larg.

Material examinado: barranco no início da Estrada da Lagoa, 21-VII-2005, G.A. Nóbrega \& M. Andrade 108 (SP); idem, 30-III-2006, J. Prado et al. 1652 (SP).

Distribuição geográfica: África, Índia, China, Malásia, Austrália, Oceania, América Central, América do Sul. No Brasil: CE, PI, PE, MT, MG, RJ, SP, PR, $\mathrm{SC}, \mathrm{RS}$.

Doryopteris concolor diferencia-se pela divisão da lâmina pedada, pinatissecta e pelo pecíolo levemente achatado a sulcado. Pode ser encontrada em área perturbada, crescendo à sombra, em meio a gramíneas.

Doryopteris lomariacea Klotzsch, Linnaea 20: 343. 1847. Tipo: "Britsh Guiana", s.d., Schomburgk 1197 (holótipo B, n.v.; isótipos BM, K, n.v.).

Figura $4 \mathrm{C}$

Plantas terrestres. Caule curto-reptante, com escamas bicolores, linear-lanceoladas, ca. $3 \mathrm{~mm}$ compr. Frondes eretas, dimorfas, fronde estéril 30-40 $\times 12-15 \mathrm{~cm}$ e fronde fértil $67-72 \times 14-12 \mathrm{~cm}$; pecíolo castanho-escuro a negro, ca. $2 \mathrm{~mm}$ diâm., cilíndrico, com tricomas esparsos, ca. $1 \mathrm{~mm}$, porção basal com escamas lanceoladas, filiformes, tortuosas, coloração semelhante à do rizoma; lâmina da fronde estéril com 5 lobos, lobos basais 3-lobados, arredondados, obtusos a agudo-lanceolados; lâmina da fronde fértil profundamente lobada, lobos lineares, coriáceos, glabros; nervuras livres, unidas somente na margem da lâmina por uma nervura inframarginal, tanto na lâmina fértil quanto na estéril. Soros contínuos sobre a margem, inclusive ao redor do sinus; indúsio com margem inteira, 0,6-0,8 $\mathrm{mm}$ larg.

Material examinado: mata de brejo, à esquerda do "Paliteiro", próximo à área invadida, 5-XI-2004, G.A. Nóbrega \& M. Andrade 86 (UNBA); margem do córrego próximo da área invadida, 30-III-2006, J. Prado et al. 1647 (SP).

Distribuição geográfica: Guiana, Peru, Bolívia, Paraguai e Brasil (BA, MG, GO, DF, SP, PR, SC, RS).

Esta espécie distingüe-se pela lâmina fértil profundamente lobada e pela venação livre, tanto na fronde fértil quanto na estéril. Pode ser encontrada na borda da Floresta Estacional Semidecidual Aluvial (mata de brejo), crescendo à sombra, em meio a gramíneas.

Equisetum L., Sp. Pl. 1061. 1753. Lectótipo: designado por Farwell, Mem. New York Bot. Gard. 6: 464. 1916: Equisetum arvense L.

Plantas terrestres ou aquáticas. Caule subterrâneo, curto a longo-reptante, com ramificações livres, caule aéreo verde, ereto, com nós e entre-nós, geralmente oco e ramificado, ramificação axilar verticilada ou não; lâmina foliar muito reduzida, não funcional, fundidas lateralmente, formando uma bainha ao redor dos nós, porção superior mais ou menos prolongada em dentes; nervura única. Estróbilos terminais; esporangióforos pedicelados, peltados, verticilados, hexagonais, apicalmente achatados, cada um com 6 grandes esporângios na superfície interna, com deiscência longitudinal; esporos esféricos, clorofilados, com quatro elatérios higroscópicos em forma de fita, superfície granulosa e com grandes depósitos esféricos.

Equisetum possui 15 espécies, com distribuição cosmopolita, exceto na Austrália e Nova Zelândia (Hauke 1995). Mickel \& Beitel (1988) consideraram dois subgêneros em Equisetum, o subg. Equisetum e o subg. Hippochaete, que diferem pela localização dos estômatos, presença de dimorfismo e a quantidade de ramos. Equisetum pode ser reconhecido pelo caule aéreo, nitidamente dividido em nós e entre-nós, pela 
bainha de folhas vestigiais ao redor dos nós e pelos estróbilos terminais.

Equisetum giganteum L., Syst. Nat. (ed. 10) 2: 1318. 1759. Lectótipo: designado por Proctor, Ferns Jam.: 18. 1985: Plumier, Pl. Amer. tab. 125, fig. 2. 1757, baseado em um material provavelmente coletado por Plumier em Hispaniola.

Figura 4 D-E

Plantas terrestres. Caule com porção rizomatosa curta, parte aérea oca. Ramo principal ca. 1,8-3 × 0,04-0,2 m, verde, ramificado verticiladamente, com 40-45 nós, envolvidos externamente por uma bainha de folhas vestigiais e por uma membrana internamente; ramos em verticilos regulares, ca. 30-40 cm compr, perpendiculares a ascendentes, com nós e entre nós, similares aos do ramo principal; bainha de folhas vestigiais, aclorofiladas, envolvendo o ápice de cada entre nó, pequenas, ca. $1 \mathrm{~cm}$ compr. no ramo principal, ápice com prolongamentos em forma de escama, ca. $5 \mathrm{~mm}$ compr., escura no centro; nervura única. Estróbilos apicais, nas extremidades dos ramos, mucronados; esporângios sésseis, sobre esporangióforos peltados.

Material examinado: mata de galeria, à direita da ponte da Trilha de Visitação, 17-V-2004, G.A. Nóbrega \& M. Andrade 70 (UNBA); margem do Córrego Vargem Limpa (Paliteiro), próximo da área invadida, 30-III-2006, J. Prado et al. 1646 (SP).

Distribuição geográfica: Grandes Antilhas, Colômbia, Venezuela, Equador, Peru, Bolívia, Chile, Argentina, Paraguai, Uruguai e Brasil (amplamente distribuída, porém sem registros confiáveis na literatura).

Caracteriza-se pelos ramos em verticilos regulares, perpendiculares a ascendentes e por apresentar estróbilos apicais, mucronados, nas estremidades dos ramos. Foi encontrada próxima ao Córrego Vargem Limpa, formando uma grande população na área.

Lindsaea Dryand. in Sm., Mém. Acad. Roy. Sci. (Turin) 5: 401. 1793. Tipo: Lindsaea trapeziformis Dryand. (= Lindsaea lancea (L.) Bedd.).

Plantas terrrestes, rupícolas ou epífitas. Caule curto a longo-reptante, escamoso. Frondes monomorfas a levemente dimorfas (a fronde fértil maior e mais ereta que a estéril), cespitosas ou espaçadas; lâmina 1-2-pinada, imparipinada, cartácea a subcoriácea; pinas inteiras dimidiadas (arredondadas, quadrangulares ou subtrapeziformes) ou 1-pinadas, opostas a alternas, glabras; pínulas, quando presentes, dimidiadas, arredondadas, quadrangulares ou subtrapeziformes; venação aberta ou areolada, sem vênulas livres inclusas nas aréolas. Soros submarginais, na porção distal ou acroscópica das pinas ou pínulas; indúsio abaxial, com abertura extrorsa, contínuo ou interrompido; esporângios pedicelados com ânulo vertical interrompido pelo pedicelo; esporos triletes ou monoletes.

Lindsaea é um gênero com ca. de 150 espécies, sendo aproximadamente 1/3 da América Tropical, ainda que a maioria seja do sudeste da Ásia e áreas do Pacífico adjacentes (Mickel \& Smith 2004). Conforme Mickel \& Smith (2004), o gênero pode ser confundido com Adiantum pela divisão da lâmina, formato dos segmentos e disposição marginal dos soros, porém Lindsaea distingüe-se pela raque paleácea e pelo indúsio abaxial e com abertura extrorsa.

\section{Chave para as espécies de Lindsaea}

1. Lâmina 1-pinada L. lancea var. lancea

1. Lâmina 2-pinada

2. Raque cilíndrica na superfície abaxial, com alas amarelas a verdes .................... L. divaricata

2. Raque quadrangular na superfície abaxial, com alas castanho-avermelhadas a estramíneas ........ .... L. quadrangularis subsp. quadrangularis

Lindsaea divaricata Klotzsch, Linnaea 18: 547. 1844. Tipo: GUIANA. Sem localidade, s.d, Schomburgk 368 (holótipo B, n.v.).

\section{Figura 4 F-G}

Plantas terrestres. Caule longo-reptante, com escamas linear-lanceoladas, castanho-escuras, 1-2 $\mathrm{mm}$ compr. Frondes monomorfas, 1-1,2 m compr.; pecíolo longo, 2/3 do compr. total da fronde, castanho-avermelhado, arredondado na superfície abaxial e sulcado adaxialmente, com escamas iguais às do caule na porção basal; lâmina 2-pinada; raque e raquíolas catanho-avermelhadas, cilíndrica na superfície abaxial, semelhantes ao pecíolo, e com alas amareladas a verdes; pinas 5-6 pares, espaçadas quase uniformemente ao longo da raque, ápice gradualmente reduzido a um segmento terminal conspícuo, base alargada; pínulas 22-35 pares, dimidiadas, 10-15 × 4-6 $\mathrm{mm}$, sésseis a curto-pecioluladas, margem inteira a levemente ondulada; venação aberta, nervuras 2-7-furcadas. Soros contínuos na superfície abaxial; esporos aclorofilados, triletes. 
Material examinado: mata de brejo (Paliteiro), 21-V-2004, G.A. Nóbrega \& M. Andrade 75 (UNBA).

Distribuição geográfica: Guatemala, Guadeloupe, Panamá, Colômbia, Venezuela, Guiana, Suriname, Guiana Francesa, Equador, Peru, Bolívia, Paraguai e Brasil (AM, GO, MT, SP).

Diferencia-se pelo pecíolo castanho-avermelhado, arredondado abaxialmente e por apresentar alas amplas, amarelas a verdes na raque e costa. Pode ser encontrada crescendo à sombra, em ambiente paludoso, próxima a Blechnum brasiliense.

Lindsaea lancea (L.) Bedd. var. lancea, Ferns Brit. India Supll.: 6. 1876 = Adiantum lancea L., Sp. Pl., ed. 2, 1557. 1763. Tipo: Lectótipo designado por Kramer, Acta Bot. Neerl. 6: 240. 1957: SURINAME. Seba, Locupl. Nat. Thes. 2: tab. 64, fig. 7-8. 1735.

Plantas terrestres. Caule curto-reptante, com escamas linear-lanceoladas, acuminadas, castanhas, ca. $1 \mathrm{~mm}$ compr. Frondes monomorfas, eretas, 30-36 cm compr.; pecíolo castanho-escuro, ocasionalmente esverdeado a estramíneo, com escamas na porção basal semelhantes às do caule, sulcado adaxialmente, glabro, ca. $12,5 \times 1 \mathrm{~mm}$; lâmina 1-pinada; raque castanha a estramínea, com alas na superfície adaxial e circulares abaxialmente; pínulas 34-37 pares, dimidiadas, semilunares na porção mediana, 1,3-1,32 ×0,6-0,7 cm, subopostas a alternas, margens inteiras a levemente onduladas, curto-pecioluladas, peciólulo ca. $1 \mathrm{~mm}$ compr., as distais gradualmente reduzidas, com pínula terminal hastada ou deltóide, base inequilateral e pínulas proximais falcadas; venação aberta, nervuras várias vezes furcadas, com extremidade expandida. Soros contínuos ou às vezes interrompido nas pinas maiores; esporos aclorofilados, triletes.

Material examinado: mata de brejo, Paliteiro, 10-IX-2006, G A. Nóbrega \& M. Andrade 125 (SP).

Distribuição geográfica: México, América Central, Antilhas, Colômbia, Venezuela, Guiana, Suriname, Guiana Francesa, Equador, Peru, Bolívia, Paraguai e Brasil (RO, AM, PA, PI, GO, BA, MT, MG, RJ, SP, PR, SC, RS).

De acordo com Kramer (1957), esta forma 1-pinada é a menos encontrada e a mais variável, tratada anteriormente como Lindsaea falcata var. lancea (L.) Jenman. Porém as duas formas, 1-pinada e 2-pinada (a mais comum), podem ocorrer juntas num mesmo caule, deixando evidente a delimitação da espécie. No JBMB a espécie ocorre na Floresta Estacional Semidecidual Aluvial (mata de Brejo), em ambiente sombreado, crescendo isoladamente.

Lindsaea quadrangularis Raddi subsp. quadrangularis, Opusc. Sci. Bol. 3: 294. 1819. Tipo: BRASIL. Vizinhanças do Rio de Janeiro: s.d, Raddi s.n. (holótipo PI, n.v.).

Figura 4 H-I

Plantas terrestres. Caule reptante, com escamas lanceoladas, acuminadas, ca. $1 \mathrm{~mm}$ compr. Frondes monomorfas, 50-65 cm compr.; pecíolo castanhoavermelhado na porção proximal e estramíneo distalmente, superfície abaxial angular ou subterete e superfície adaxial quadrangular, porção basal com poucas escamas, semelhantes às do caule; lâmina 2-pinada, com 2-6 pares de pinas e pina terminal conforme; raque e raquíola castanho-avermelhadas a estramíneas, quadrangular em ambas as superfícies, com alas estreitas de mesma coloração; pinas subopostas ou alternas, oblongo-lanceoladas, ascendentes, 16-23 cm compr., ápice gradualmente reduzido; pínulas dimidiadas, alternas, 7-11 × 4-6 $\mathrm{mm}$, curto-pecioluladas, peciólulo ca. $0,2 \mathrm{~mm}$ compr., uma pínula axilar fortemente reduzida freqüentemente presente, margem inteira a levemente ondulada, ligeiramente curvada na fronde fértil; nervuras 3-6-furcadas. Soros contínuos, com indúsio delicado, paleáceo; esporos aclorofilados, monoletes.

Material examinado: trilha de acesso à lagoa, brejo próximo da área invadida, 30-III-2006, J. Prado et al. 1649 (SP).

Distribuição geográfica: Endêmica do Brasil (PE, MG, RJ, SP, PR).

Kramer (1957) reconheceu quatro subespécies para esta espécie e as separou pelas seguintes características: forma do ápice da pina e tamanho do segmento terminal (ápice pouco reduzido, com segmento terminal grande ou fortemente reduzido, com segmento terminal pequeno), coloração da raquíola e formato (sulcado, côncavo ou plano) e tipos de esporos (triletes ou monoletes).

Háduas subespécies no Brasil(subsp.quadrangularis e subsp. terminalis). O material do JBMB enquadrase na subsp. quadrangularis pelo ápice das pinas gradualmente reduzidos com um segmento terminal pequeno e os esporos monoletes. A subespécie terminalis, diferencia-se desta pelo ápice das pinas 
menos reduzido, com um segmento terminal grande e os esporos triletes. Pode ser encontrada na borda da Floresta Estacional Semidecidual Aluvial (mata de brejo), crescendo junto a gramíneas.

Lycopodiella Holub, Preslia 36: 22. 1964 ELycopodium subgen. Lycopodiella (Holub) B. Øllg., Amer. Fern J. 69: 49. 1979. Tipo: Lycopodium inundatum L. (= Lycopodiella inundata (L.) Holub.).

Plantas terrestres, rupícolas ou epífitas. Esporófito ramificado, com ramos prostrados radicantes ou arqueados, com crescimento indeterminado; ramos estrobilíferos eretos, simples (seção Lycopodiella e seção Caroliniana) a três vezes furcados, originandose no dorso do caule reptante, com ramos longoescandentes ou arqueados, espaçadamente radicantes em longos intervalos, formando um sistema de râmulos horizontais, de arranjo subdecussado, esparramados a pendentes; microfilos isofilos ou levemente anisofilos; esporofilos subpeltados, com uma lamela basiscópica mediana (seção Lycopodiella e seção Caroliniana) ou com membranas coalescentes basais que envolvem o esporângio (seção Campylostachys); nervura única; esporângios sobre a base do esporofilo ou axilares (seção Lycopodiella), marcadamente anisovalvados ou isovalvados (seção Caroliniana); células da epiderme do esporângio com paredes delgadas, retas, não lignificadas; esporos rugosos, aclorofilados, triletes.

Gênero cosmopolita com aproximadamente 40 espécies (Øllgaard 1995). De acordo com Øllgaard \& Windisch (1987), a maioria delas ocorre nas Américas, sendo que as espécies brasileiras podem ser divididas em três seções: seção Campylostachys, seção Caroliniana e seção Lycopodiella. Neste trabalho foram encontradas representantes de duas seções: Campylostachys e Lycopodiella. Este gênero de forma geral pode ser caracterizado pelos ramos estrobilíferos eretos, simples a três vezes furcados originando-se no dorso do caule reptante.

Chave para as espécies de Lycopodiella

1. Esporófito com ramos estrobilíferos curvados no ápice, fasciculados; esporofilos com bases coalescentes; esporângios na base dos esporofilos L. camporum

1. Esporófito com ramos estrobilíferos eretos, simples ou uma vez furcados; esporofilos sem bases coalescentes; esporângios axilares

L. alopecuroides var. integerrima
Lycopodiella alopecuroides (L.) Cranfill var. integerrima (Spring) B. Øllg. \& P.G. Windisch, Bradea 5: 29.1987 $\equiv$ Lycopodium alopecuroides L. var. integerrimum Spring, Mém. Acad. Roy. Belg. 15: 75. 1842. Tipo: "BRASIL. Ilha de Santa Catarina", s.d., Macrae s.n. (holótipo E, n.v; isótipo K, n.v.).

Plantas terrestres. Esporófito com ramos prostrados e eretos; ramos estrobilíferos eretos, simples ou uma vez furcados, $36-65 \mathrm{~cm}$ compr., flexíveis; microfilos dos ramos eretos 7-8 $\mathrm{mm}$ compr. em numerosas séries, ocultando o talo em verticilos alternos de 6 ou mais; microfilos dos ramos prostrados $4-5 \mathrm{~mm}$ compr., linear-lanceolados a lanceolados, margens inteiras a denticuladas, dentes patentes a uncinados. Estróbilos eretos, 11-26 × 0,8-1 cm (incluindo os esporofilos), no final de ramos simples, eretos, que surgem dorsalmente sobre o talo rasteiro; esporofilos ca. $5 \mathrm{~mm}$ compr. um pouco mais largos que as folhas adjacentes do pedúnculo, mais de 10-seriados, subpeltados, linear-lanceolados a lanceolados, com dentes patentes a uncinados sobre as margens, sem bases coalescentes; esporângios ca. $1 \mathrm{~mm}$ diâm., anisovalvados, axilares e globosos.

Material examinado: brejo da Unesp, após a torre de alta tensão, 4-X-2005, G.A. Nóbrega \& M. Andrade 115 (SP).

Distribuição geográfica: Leste dos Estados Unidos da América, Sul do México, Mesoamérica, Colômbia, Venezuela, Equador, Peru, Bolívia, Paraguai, Uruguai e Brasil (RR, RO, MT, GO, DF, MG, BA, ES, RJ, SP, PR, SC, RS).

De acordo com Øllgaard \& Windisch (1987), esta espécie ocorre na América Tropical do nível do mar até $2.300 \mathrm{~m}$ de altitude, em locais abertos e úmidos, em solo argiloso ou arenoso. No Brasil podem ser encontradas três variedades desta espécie, Lycopodiella alopecuroides var. duseniana B. Øllgaard \& P. G. Windisch, L. alopecuroides (L.) Cranfill var. integerrima (Spring) B. Øllgaard \& P. G. Windisch e L. alopecuroides var. tupiana B. Øllgaard \& P. G. Windisch. Na área de estudo foi encontrada apenas L. alopecuroides var. integerrima e esta variedade pode ser distingüida pelos ramos estrobilíferos eretos, simples ou uma vez furcados, sendo encontrada em áreas de campo, crescendo junto a gramíneas.

Lycopodiella camporum B. Øllg. \&. P.G. Windisch, Bradea 5(1): 24, fig. 3. 1987. Tipo: "BRASIL. Minas Gerais: Mun. Santana do Riacho, estrada 
Lagoa Santa - Conceição do Mato Dentro, km 113, Serra do Cipó, córrego do Vitalino, alt. 1.150 m, campo rupestre, parte alta do barranco do córrego, inundada durante as cheias, 1-II-1987, J. Prado et al. 69 (holótipo HB, n.v.; isótipos AAU, RB, SP!, SPF).

Plantas terestres. Esporófito com ca. 0,47-1,13 $\mathrm{m}$ compr., com ramos arqueados curtos a longos, do qual partem ramos dorsais, eretos, rijos, com râmulos laterais agregados, fasciculados, ascendentes, rijos, ápice ereto nos râmulos estéreis e curvado abruptamente nos férteis; microfilos dos râmulos ca. 2-4 mm compr., congestos, adpressos a patentes, aciculares, cilíndricos, base levemente achatada, margem lisa a ciliada. Estróbilos sésseis, terminais $1-1,5 \times 0,2-0,3 \mathrm{~cm}$, sobre as extremidades dos râmulos curvos; esporofilos 1-2 mm compr., ovais, longo-acuminados, margem erodida a irregularmente fimbriada, com bases coalescentes quase envolvendo os esporângios; esporângios na base dos esporofilos, anisovalvados.

Material examinado: área de brejo, próximo à lagoa, 30-I-2004, G.A. Nóbrega et al. 22 (UNBA); idem, 10-III-2004, G.A. Nóbrega et al. 58 (UNBA).

Distribuição geográfica: Venezuela, Guiana, Colômbia, Bolívia, Peru, Paraguai e Brasil (AM, PA, RR, RO, BA, DF, GO, MG, SP, PR).

Segundo Øllgaard \& Windisch (1987), esta espécie ocorre entre 440 e $1.800 \mathrm{~m}$ de altitude, sendo mais comum entre 600 e 1.200 m; pode ser encontrada em locais brejosos, campos úmidos, solo turfoso ou arenoso, freqüentemente na vegetação aberta junto às formações de galeria dos rios. Caracteriza-se pelo caule ereto partindo dorsalmente do ramo prostrado, pelos ramos de tamanhos desiguais e pelos estróbilos pendentes e sésseis, eretos e terminais. $\mathrm{Na}$ área do JBMB foi encontrada no interior e na borda da Floresta Estacional Semidecidual Aluvial (mata de brejo), em pleno sol ou em locais sombreados.

Macrothelypteris (H. Itô) Ching, Acta Phytotax. Sinica 8: 308. $1963 \equiv$ Thelypteris sect. Macrothelypteris $\mathrm{H}$. Itô in Nakai \& Honda, Nov. Fl. Jap. 4: 141. 1939. Tipo: Thelypteris oligophlebia (Baker) Ching (= Macrothelypteris torresiana (Gaud.) Ching.).

Plantas terrestres. Caule curto-reptante a subereto. Frondes monomorfas; pecíolo com dois feixes vasculares na base; lâmina 2-pinada a 2-pinado-pinatífida ou mais dividida, base alargada, ápice gradualmente reduzido; pinas 1-pinadopinatífidas, sésseis ou pediceladas, pinas proximais não reduzidas ou pouco reduzidas, com pínulas adnadas; venação aberta; indumento de tricomas aciculares e septados. Soros arredondados, medianos a supramedianos; indúsio pequeno, freqüentemente obscurecido no soro maduro; esporângios com ânulo vertical interrompido pelo pedicelo; esporos aclorofilados, monoletes.

Segundo Smith (1992), Macrothelypteris compreende ca. de 10 espécies nativas das regiões tropicais e subtropicais da África, Ásia, Ilhas do Pacífico e Queensland. O gênero pode ser reconhecido pela divisão da lâmina 2-pinado-pinatífida sendo, por esta característica, muitas vezes confundido com Ctenitis. Porém, Macrothelypteris está mais relacionado com Thelypteris por possuir apenas dois feixes vasculares na porção basal do pecíolo, enquanto Ctenitis possui numerosos feixes.

Macrothelypteris torresiana (Gaud.) Ching, Acta Phytotax. Sinica 8: 310. 1963 三 Polystichum torresianum Gaud. in Freyc., Voy. Uranie. 333. 1828. Tipo: ILHAS MARIANAS. Sem localidade, s.d., Gaudichaud s.n. (holótipo P, n.v.).

Plantas terrrestres. Caule curto-reptante, com escamas lanceoladas, castanhas, tortuosas, ápice longo-acuminado, ca. 0,5-1 cm compr., pubescentes na margem e superfície. Frondes ca. $80-90 \mathrm{~cm}$ compr.; pecíolo estramíneo ou esverdeado, 1-2 mm diâm., com escamas na porção basal semelhantes às do caule; lâmina cartácea, 2-pinado-pinatífida, par de pina proximal maior ou ligeiramente reduzido; raque com tricomas pluricelulares na superfície adaxial, sulcada ou não adaxialmente; pinas 1-pinado-pinatífidas, $11-14 \times 2,5-4 \mathrm{~cm}$, peciólulo ca. $1 \mathrm{~mm}$ compr.; pínulas 1,5-2 $\times 0,3-0,6 \mathrm{~cm}$, curtopecioluladas a ligeiramente adnadas; segmentos ca. $1 \mathrm{~mm}$ larg., margem inteira a levemente ondulada; nervuras livres, furcadas; indumento de tricomas pluricelulares na superfície abaxial, tortuosos, ca. $2 \mathrm{~mm}$ compr., sobre costa, cóstula e nervuras e adaxialmente sobre a raque e raquíola, $0,5-1 \mathrm{~mm}$ compr.; tricomas setiformes sobre a superfície adaxial, sobre costa, cóstula e nervuras, ca. $0,5 \mathrm{~mm}$ compr.; glândulas capitadas inconspícuas, às vezes presentes sobre os eixos e tecido laminar. Soros medianos, arredondados, indúsio esparsamente pubescente, receptáculo glabro; esporângios com glândulas capitadas próximas ao ânulo. 
Material examinado: mata de brejo junto ao Córrego

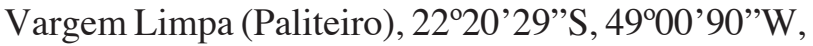
303 m alt., 30-III-2006, J. Prado et al. 1637 (SP).

Distribuição geográfica: Estados Unidos da América, Antilhas, México até o Panamá, Colômbia até a Bolívia, Argentina, Paraguai, Brasil (PE, BA, GO, DF, MT, MS, ES, RJ, MG, SP, PR e SC). Também ocorre nas Ilhas do Pacífico, regiões tropicais e subtropicais da África e Ásia (Smith 1992).

Esta é a única espécie de Macrothelypteris introduzida e amplamente distribuída no Neotrópico. Pode ser caracterizada pela fronde 2-3-pinadopinatífida, com dois feixes vasculares na porção basal do pecíolo. Foi encontrada apenas uma planta na área do JBMB, crescendo em ambiente paludoso, próximo ao córrego.

Microgramma C. Presl, Tent. Pterid.: 213, tab. 9, fig. 7. 1836. Tipo: Polypodium persicariifolium Schrad. (= Microgramma persicariifolia (Schrad.) C. Presl).

Plantas epífitas ou raramente rupícolas. Caule longo-reptante, ramificado, coberto por escamas aciculares a lanceoladas, mono ou bicromáticas, peltadas, margem inteira ou fimbriada, com poucas a muitas raízes fibrosas. Frondes monomorfas a dimorfas (as férteis mais estreitas e longas que as estéreis) com até $35 \mathrm{~cm}$ compr.; pecíolo pequeno, articulado a um filopódio curto; lâmina inteira, pouco pubescente, esparsa a moderadamente escamosa ou glabra, escamas arredondadas ou lanceoladas; venação aberta ou areolada, com nervuras livres inclusas nas areolas. Soros arredondados a alongados, formando uma fileira de cada lado da costa, no ápice de uma única nervura ou na junção de mais nervuras ou, ainda, ao longo das nervuras (apenas em M. persicariifolia) em um receptáculo proeminente; esporângios com paráfises filamentosas, simples, ramificadas ou dendríticas, então escamiformes, com porção laminar subterminal, nunca peltadas e sempre diferentes do indumento laminar; indúsio ausente; esporângios gabros, com ânulo vertical interrompido pelo pedicelo; esporos aclorofilados, monoletes.

Microgramma é um gênero com ca. de 20 espécies neotropicais e 1-2 espécies na África. Caracteriza-se pelas frondes subdimorfas a dimorfas, nervuras reticuladas, escamas do caule peltadas, não clatradas, e soros unisseriados com paráfises escamiformes (Mickel \& Smith 2004).
Chave para as espécies de Microgramma

1. Frondes sésseis; costa com escamas castanhas, lineares a lanceoladas na face abaxial M. lindbergii

1. Frondes pecioladas; costa com escamas alvas, ovais a oblongo-lanceoladas na face abaxial ........ M. squamulosa

Microgramma lindbergii (Mett. ex Kuhn) de la Sota, Opera Lilloana 5: 56, fig. 2, 5. 1961 = Polypodium lindbergii Mett. ex Kuhn, Linnaea 36: 136. 1869. Síntipos: BRASIL. Rio DE JANEIRO: s.d., Beyrich, Helmreicher 198 (B, n.v.); Minas GeraIs, s.d., G.A. Lindberg 576 (B, n.v.).

Figura 5 A-B

Plantas epífitas. Caule ca. 2-4 mm diâm., ramificado, coberto por escamas bicromáticas, 4-7 mm compr., com tricomas nas superfícies, margens inteiras. Frondes monomorfas, 23-15 × 1,6-2,8 $\mathrm{cm}$, sésseis, oblongo-lanceoladas, membranáceas a cartáceas; lâmina inteira, com tricomas esparsos na superfície abaxial e glabra adaxialmente, margens inteiras; costa proeminente, com escamas na superfície abaxial, castanhas, peltadas, base arredondada, ápice longamente acuminado, ca. $1 \mathrm{~mm}$ compr.; venação areolada, com nervuras livres inclusas nas aréolas. Soros arredondados, inframedianos, entre a margem e a costa, sobre o ápice de uma vênula livre; paráfises filiformes, maiores que os esporângios.

Material examinado: mata de brejo (Paliteiro), 30-I-2004, G.A. Nóbrega et al. 27 (UNBA); idem, ca. $5 \mathrm{~m}$ do Córrego Vargem Limpa, 10-III-2004, G.A. Nóbrega et al.63 (UNBA); mata de brejo, junto ao Córrego Vargem

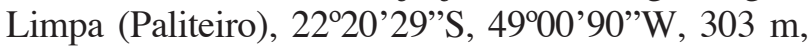
30-III-2006, J. Prado et al. 1639 (SP).

Distribuição geográfica: Colômbia, Equador, Peru, Paraguai, Argentina e Brasil (MG, MT, DF, SP, PR, $\mathrm{SC})$.

Microgramma lindbergii pode ser diferenciada pelas frondes sésseis e pelas lâminas pubescentes ou escassamente pubescentes em ambas as faces. $\mathrm{Na}$ área do JBMB pode ser facilmente encontrada na Floresta Estacional Semidecidual Submontana, crescendo à sombra.

Microgramma squamulosa (Kaulf.) de la Sota, Opera Lilloana 5: 59, fig. 2, 3, 6, 7. 1961 = Polypodium squamulosum Kaulf., Enum. Fil.: 89. 1824. Tipo: BRASIL. "Insula Santa Catarina, Chamisso", s.n. (holótipo: provavelmente em LE, n.v.). 


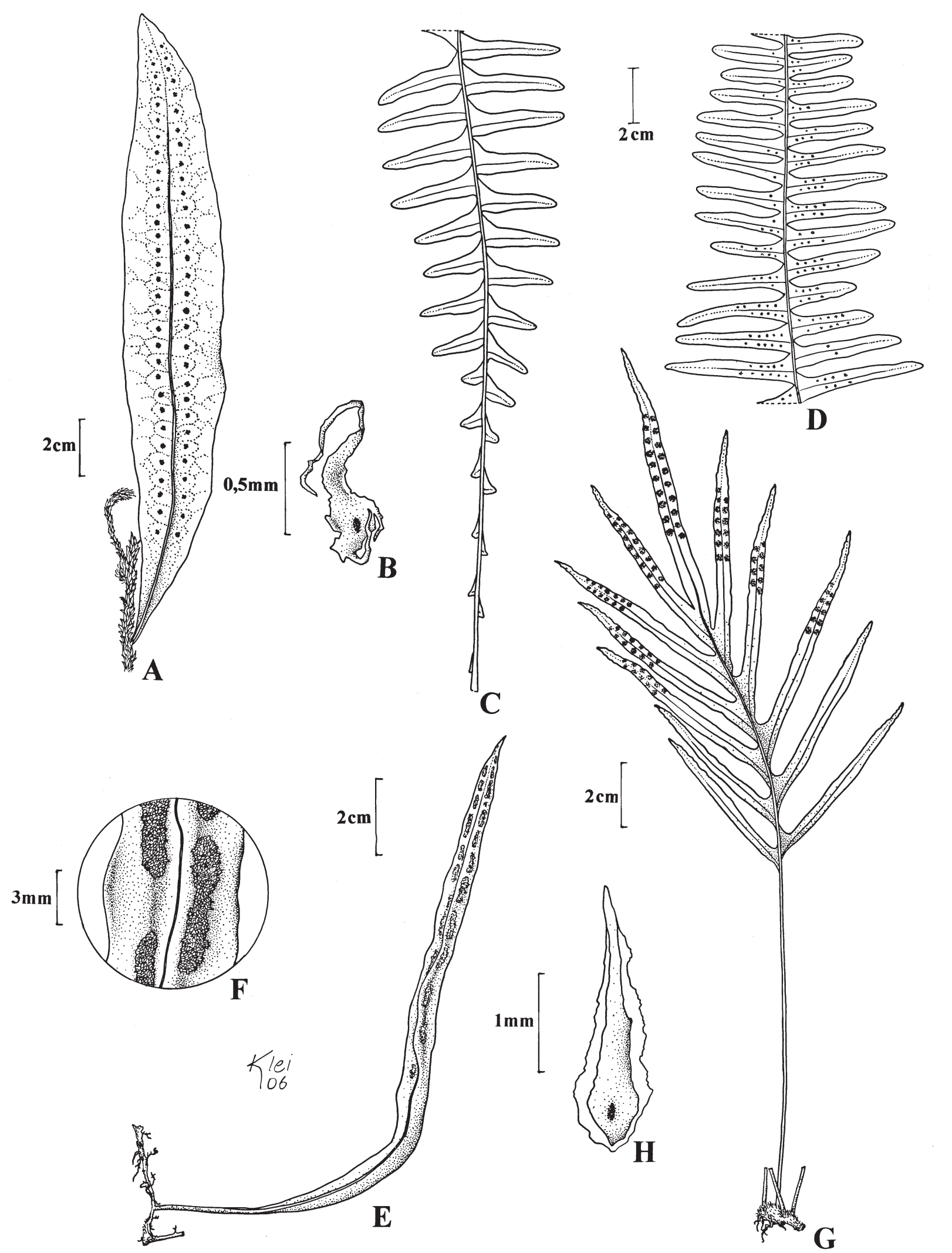

Figura 5. A-B. Micrograma lindbergii. A. Hábito. B. Escama da costa. C-D. Pecluma paradiseae. C. Porção proximal de uma fronde estéril. D. Segmentos férteis. E-F. Pleopeltis astrolepsis. E. Hábito. F. Detalhe do soro. G-H. Pleopeltis pleopeltifolia. G. Hábito. H. Escama do caule. 
Plantas epífitas. Caule ca. 3 mm diâm., coberto por escamas castanho-claras, margens fimbriadas, 4-5 $\mathrm{mm}$ compr. Frondes eretas, cartáceas a subcoriáceas, inteiras, dimorfas; fronde estéril elíptica a oblonga, ca. $12-15 \times 2,5 \mathrm{~cm}$; fronde fértil linear-lanceolada, 9-14 $\times 0,5-1,6 \mathrm{~cm}$; pecíolo 0,1-0,2 cm diâm., levemente alado, com escamas esparsas, semelhantes às do caule, um pouco mais claras e com margens hialinas; lâmina com escamas, alvas, ovais a oblongo-lanceoladas, base arredondada, ápice acuminado, margens fimbriadas, 0,5-2 mm compr.; costas abaxialmente proeminentes, com escamas iguais às da lâmina; venação areolada, com nervuras livres inclusas nas aréolas. Soros arredondados, medianos, entre a margem e a costa, sobre 2 ou 3 nervuras; paráfises filiformes, do mesmo comprimento dos esporângios.

Material examinado: trilha de acesso à lagoa, na Savana Estacional Florestada, 30-I-2004, G.A. Nóbrega et al. 6 (UNBA); trilha de acesso à lagoa, na Floresta Estacional Semidecidual Submontana, 22-XII-2005, G.A. Nóbrega \& M. Andrade 122 (SP).

Distribuição geográfica: Peru, Paraguai, Uruguai, Argentina e Brasil (MT, BA, MG, RJ, SP, PR, SC, RS).

De acordo com Sota (1960), o dimorfismo foliar desta espécie pode ser acentuado ou praticamente nulo. Os espécimes aqui estudados apresentaram a largura da lâmina variando de 0,5 a 1,6 cm. Microgramma squamulosa caracteriza-se por apresentar frondes com pecíolo levemente alado e lâmina com escamas lanceoladas, alvas, com margens fimbriadas na superfície abaxial. Pode ser encontrada na área do JBMB na Floresta Estacional Semidecidual Submontana e na Savana Estacional Florestada (Cerradão).

Nephrolepis Schott, Gen. Filic.: tab. 3. 1834. Tipo: Polypodium exaltatum L. (= Nephrolepis exaltata (L.) Schott).

Plantas terrestres, epífitas ou rupícolas. Caule ereto a reptante, estolonífero ou não, com escamas e poucas a muitas raízes fibrosas. Frondes monomorfas, fasciculadas, cespitosas; pecíolo com três feixes vasculares na porção basal, contínuo com o caule, glabro ou escamoso; lâmina 1-pinada, glabra, pilosa ou escamosa; raque sulcada adaxialmente, escamosa, pilosa ou glabra; pinas alternas, inteiras, glabras a pubescentes, articuladas com a raque; nervuras livres, terminando em hidatódios próximos da margem. Soros arredondados a reniformes, sobre a extremidade das nervuras, submarginais a eqüidistantes; indúsio reniforme, semilunar ou orbicular-reniforme, peltado ou com um sinus largo ou estreito, glabro ou pubescente; esporângios com ânulo interrompido pelo pedicelo; esporos aclorofilados monoletes.

Este gênero ocorre em regiões tropicais e subtropicais, sendo composto por aproximadamente 30 espécies. Pode ser caracterizado pela lâmina 1-pinada, pecíolo contínuo com o caule e soros no ápice das nervuras (Nauman 1995).

Nephrolepis pectinata (Willd.) Schott, Gen. Fil. t.

3. $1834 \equiv$ Aspidium pectinatum Willd., Sp. Pl. 5:

223. 1810. Tipo: “ex Aiton” (holótipo Herb. Willd.

19753. B).

Plantas epífitas. Caule ereto, estolonífero, com escamas castanhas, lanceoladas, peltadas, ca. $2 \mathrm{~mm}$ compr. Frondes 45-85 cm compr.; pecíolo estramíneo a castanho-escuro, com escamas lanceoladas, peltadas, castanho-claras a castanho-avermelhadas, escuras na base, margens levemente fimbriadas, ca. $4 \mathrm{~mm}$ compr.; lâmina pinada, linear-lanceolada; raque castanho-escura com escamas semelhantes na forma às do pecíolo, com coloração castanho-avermelhada a castanho-escura; pinas 2-2,7 cm compr., oblongolanceoladas, expandidas na base, cuneadas no lado basioscópico e auriculadas no lado acroscópico, margem crenulada, glabras; nervuras 1-2-furcadas com ápice expandido, próximo da margem da lâmina. Soros submarginais; indúsio reniforme com sinus largo e margem inteira; esporângios projetando-se para fora do indúsio em direção ao ápice da pina.

Material examinado: entrada à esquerda da Ponte de Visitação, lado direito, $600 \mathrm{~m}$ da lagoa, 18-X-2006, G.A. Nóbrega et al. 126 (SP).

Distribuição geográfica: México, Honduras até o Panamá, Grandes Antilhas, Colômbia, Venezuela, Bolívia, Brasil (AM, MG, RJ, SP, PR, SC).

Nephrolepis pectinata é comumente encontrada em baixas altitudes e diferencia-se pela lâmina pectinada, caule estolonífero e indúsio reniforme com sinus amplo e esporângios projetando-se para fora em direção ao ápice da pina (Prado 2005). No local estudado ela cresce em uma área parcialmente perturbada, em solo escuro e úmido e forma uma grande população.

Osmunda L., Sp. Pl.: 1063. 1753. Tipo: O. regalis L.

Plantas terrestres. Caule decumbente a ereto, indumento ausente, lignificado, com raízes fibrosas, 
subterrâneas a parcialmente aéreas. Frondes variando de monomorfas, hemidimorfas (parte da lâmina estéril e parte fértil) a dimorfas (os segmentos férteis mais estreitos), cespitosas; pecíolo com base expandida, laminar, com tricomas, com um feixe vascular em forma de "U" na base; lâmina 1-2-pinado-pinatífida, cartácea a subcoriácea, lâmina estéril comumente glabra na maturidade; raque com tricomas moderados a esparsos; venação aberta. Soros recobrindo a superfície abaxial da lâmina, formados sobre o tecido lâminar, dispostos geralmente nas pinas distais ou em todas as partes da lâmina; esporângios confluentes na maturidade, relativamente grandes, comumente em cachos sobre os segmentos da lâmina fértil, ânulo vestigial; esporos clorofilados, tetraédricosglobosos.

De acordo com Palacios-Rios (1995), este é um gênero com ca. de 15 espécies. Porém, Mickel \& Smith (2004) citam 10 espécies de Osmunda para regiões temperadas e subtropicais. Essas espécies geralmente crescem em áreas pântanosas, em regiões tropicais ou temperadas de ambos os hemisférios (Tryon \& Stolze 1989). O gênero pode ser reconhecido pelas frondes dimorfas ou hemidimorfas, 1-pinadas ou mais divididas, pelas nervuras livres, pelo caule com indumento de tricomas e pelos esporos globosos clorofilados.

Osmunda regalis L. var. spectabilis (Willd.) A. Gray, Manual ed. 2: 600. 1856 O Osmunda spectabilis Willd., Sp. Pl. 5: 98. 1810. Tipo: ESTADOS UNIDOS DA AMÉRICA. Pennsylvania: s.d, Mühlenberg s.n. (holótipo B, Herb. Willd. 19504, n.v.; foto GH, n.v.).

Plantas terrestres. Caule massivo, ereto, ca. 3-6 cm diâm. Frondes 0,7-1,14 m compr., cespitosas, hemidimorfas (parte da lâmina estéril e parte fértil), com as pinas férteis apenas na porção distal; pecíolo castanho na base e estramíneo a esverdeado para o ápice, 26-58 cm compr., glabro ou com tricomas moderados na base, castanhos, ca. 0,5-1 mm compr.; porção estéril da lâmina 2-pinada; pinas oblongolanceoladas a oblongas, $16-18 \times 4-7 \mathrm{~cm}$; pínulas oblongas, cartáceas a subcoriáceas, 2-3,5 × 0,7-1 $\mathrm{cm}$, margens denticuladas, peciólulo curto, ca. $1 \mathrm{~mm}$ compr., glabras em ambas as faces ou com tricomas articulados castanho-avermelhados, filiformes, tortuosos, ca. $1 \mathrm{~mm}$ compr., apenas na base das pínulas; raque não alada, glabra; raquíola levemente alada na superfície adaxial, com diminutos tricomas aciculares, castanho-claros a alvos, ca. 0,5 mm compr., glabra na superfície abaxial; porção fértil da lâmina 2-pinado-pinatífida; pínulas 0,5-1,5 × 0,1-0,3 cm; nervuras bifurcadas.

Material examinado: área de brejo, 14-IV-2005, G.A. Nóbrega \& M. Andrade 92 (SP).

Distribuição geográfica: amplamente distribuída no Continente Americano, Europa, Ásia e Sul da África. No Brasil: MG, RJ, SP, PR, SC, RS.

Pode ser caracterizada pela lâmina estéril 2-pinada, pela raquíola brevemente alada adaxialmente, pelas nervuras bifurcadas e pelas pínulas férteis apenas na porção distal da lâmina. Forma grandes comunidades na área paludosa do JBMB. Foi encontrada em local aberto, crescendo próxima a Equisetum giganteum.

Pecluma M.G. Price, Amer. Fern J. 73: 109. 1983. Tipo: Polypodium pectinatum L. (= Pecluma pectinata (L.) M.G. Price).

Plantas terrestres, rupículas ou epífitas. Caule horizontal, curto a longo-reptante, não ramificado, com escamas mono ou bicromáticas, basefixas, superfície glabra ou pubescente, margem inteira ou denteada. Frondes monomorfas, distantes ou agrupadas, curto a longo-pecioladas, articuladas, filopódio 1-2 mm compr.; pecíolo negro a castanho-escuro, raramente mais claro, cilíndrico; lâmina pectinada, com numerosos segmentos lineares, moderadamente elíptica a deltóide, base atenuada ou não, às vezes com poucas escamas sobre a raque, tricomas pluricelulares presentes na superfície laminar, raque e costa; venação aberta, nervuras simples a 2-furcadas, raramente venação areolada, freqüentemente com nervuras livres inclusas. Soros arredondados, surgindo sobre o ápice da primeira nervura acroscópica, em uma fileira entre a costa e a margem; esporângios com 2-3 fileiras de células no pedicelo, glabros ou com paráfises constituídas de tricomas simples, furcados ou clavados, ânulo vertical interrompido pelo pedicelo; esporos aclorofilados, monoletes.

Segundo Mickel \& Smith (2004), Pecluma apresenta cerca de 28 espécies neotropicais que podem ser diferenciadas de Polypodium pelo caule geralmente curto-reptante, não ramificado, não glauco, com escamas basefixas, não clatradas, pecíolo e raque cilíndricos e frondes pectinadas. Difere das espécies de Grammitidaceae pelos esporos bilaterais aclorofilados e pelos esporângios com duas fileiras de células no pedicelo. 
Pecluma paradiseae (Langsd. \& Fisch.) M.G. Price, Amer. Fern J. 73(3): 115. 1983 三 Polypodium paradiseae Langsd. \& Fisch., Icon. fil.: 11, tab. 11. 1810. Tipo: BRASIL. Santa Catarina: Ilha de Santa Catarina, s.d., Langsdorff s.n. (holótipo LE, Herb. Fisch., n.v.; isótipo B Herb. Willd, n.v.). Figura 5 C-D

Plantas epífitas ou terrestres. Caule longoreptante, revestido por escamas castanho-escuras, 3-5 $\mathrm{mm}$ compr., base deltóide e ápice alongado. Frondes 1,15-1,2 × 0,15-0,2 m; pecíolo cilíndrico, castanhoescuro a negro, ca. $18 \times 0,2 \mathrm{~cm}$, com tricomas aciculares pardos a alvos; lâmina oblongo-lanceolada, pinatissecta e pectinada nas porções superiores e medianas, com segmentos proximais auriculiformes, adnados e reduzidos, superfície abaxial com tricomas alvos e esparsos, principalmente na raque, costas e sobre as nervuras, margens com tricomas esparsos, superfície adaxial com densos tricomas alvos na raque e costas; segmentos lineares, os medianos ca. 9-10 × $0,8 \mathrm{~cm}$, espaçados na porção basal da lâmina, margens inteiras; nervuras livres, 1-2 furcadas, terminando próximo à margem da lâmina. Soros submarginais; esporângios com paráfises clavadas, simples.

Material examinado: área de brejo, Paliteiro, 30-I-2004, G.A. Nóbrega et al. 28 (UNBA); área de brejo, "Paliteiro", próximo ao Córrego Vargem Limpa, 21-V-2004, G.A. Nóbrega \& M. Andrade 78 (UNBA); mata de brejo junto ao Córrego Vargem Limpa, Paliteiro, 22 20'29"S, 49 00 '90"W, 303 m, 30-III-2006, J. Prado et al. 1641 (SP).

Distribuição geográfica: Endêmica do Brasil (MG, RJ, SP, PR, SC, RS).

Caracteriza-se pelo pecíolo cilíndrico, castanhoescuro a negro, com tricomas aciculares pardos a alvos, pela lâmina pinatissecta e pectinada nas porções superiores e medianas, com segmentos proximais auriculiformes, adnados e reduzidos, com indumento de tricomas aciculares, alvos, em ambas as faces. No JBMB é encontrada na Floresta Estacional Semidecidual Aluvial (mata brejo), em ambiente sombreado.

Pityrogramma Link, Handbuch 3: 19. 1833. Tipo: Acrostichum chrysophyllum Sw. (= Pityrogramma chrysophylla (Sw.) Link).

Plantas terrestres ou rupícolas. Caule curtoreptante a ereto, escamoso. Frondes monomorfas a subdimorfas, cespitosas a fasciculadas; pecíolo contínuo com o caule, freqüentemente escuro, marrom a astropúrpuro, rígido e brilhante, glabro ou escamoso na base, com mais de 3 feixes vasculares na base; lâmina geralmente lanceolada, 1-5-pinada, cartácea a coriácea, com indumento farináceo branco ou amarelo na superfície abaxial, superfície adaxial glabra; venação aberta. Soros abaxiais; esporângios dispostos ao longo das nervuras, com ânulo vertical interrompido pelo pedicelo; esporos aclorofilados, triletes.

Pityrogramma apresenta cerca de 17 espécies na América tropical (Mickel \& Smith 2004). O nome do gênero é derivado do Grego pityron (crosta ou farinha) e gramme (linha ou fileira), referentes respectivamente à superfície abaxial da lâmina coberta por indumento branco e pelos esporângios dispostos em fileiras ao longo das nervuras (Proctor 1989). Na área do JBMB foram encontradas duas espécies para o gênero.

Chave para as espécies de Pityrogramma

1. Lâmina 1-2-pinada, com pinas distais inteiras e lanceoladas P. trifoliata

1. Lâmina 2-pinado-pinatífida, com pinas distais 1-pinado-pinatífidas e deltóides........ P.calomelanos

Pityrogramma calomelanos (L.) Link, Handbuch 3: 20.1833 = Ascrostichum calomelanos L., Sp. Pl.: 1072. 1753. Tipo: localidade desconhecida (LINN-1245. 19, n.v.).

Plantas terrestres. Caule ereto, com escamas lanceoladas filiformes, castanho-escuras, brilhantes, ca. $3 \mathrm{~mm}$ compr. Frondes eretas a patentes, 48-94 $\times$ 8-16 cm; pecíolo cilíndrico, castanho-escuro a preto, brilhante, ca. $58-23 \times 0,1-0,3 \mathrm{~cm}$, com escamas na base iguais às do caule, glabro distalmente; lâmina 2-pinado-pinatífida, ca. 24-33 × 8-16 cm, cartácea, lanceolada a oval-lanceolada, com cera branca na superfície abaxial, com tricomas glandulares; raque glabra, castanho-escura a preta, brilhante, sulcada adaxialmente; pinas 1-pinado-pinatífidas, deltóides, alternas, pecioluladas, base eqüilateral, 4-15 × 0,8-4 $\mathrm{cm}$; raquíola semelhante à raque; pínulas lanceoladas a elípticas, base cuneada, margens serreadas a profundamente incisas, ápice agudo; nervuras simples; esporângios curto-pedicelados.

Material examinado: lado esquerdo do "Paliteiro", à esquerda do córrego, 5-XI-2004, G.A. Nóbrega \& M. Andrade 87 (UNBA). 
Distribuição geográfica: Estados Unidos da América (Flórida), México, América Central, Antilhas, Colômbia, Venezuela, Guiana, Suriname, Guiana Francesa, Trinidad, Equador, Peru, Bolívia, Paraguai, Argentina e Brasil (AM, GO, DF, MT, MS, PI, CE, PE, BA, MG, RJ, SP, PR, SC, RS).

Pode ser diferenciada de Pityrogramma trifoliata (L.) R.M. Tryon, a outra espécie encontrada na área estudada, pela base das pinas eqüilaterais e pela lâmina cartácea e 2-pinado-pinatífida. É encontrada no JBMB, na borda da mata de brejo, em áreas de campo, crescendo entre gramíneas.

Pityrogramma trifoliata (L.) R.M. Tryon, Contr. Gray Herb. 189: 68. 1962 = Acrostichum trifoliatum L., Sp. Pl. 2: 1070. 1753. Lectótipo: designado por Proctor, Ferns Jam.: 1985: Sloane, Voy. Jamaica 1: tab. 45, fig.2. 1707.

Plantas terrestres. Caule ereto, ápice com escamas castanho-escuras, linear-lanceoladas, basefixas, ca. 3 $\mathrm{mm}$ compr. Frondes monomorfas, $48-65 \mathrm{~cm}$ compr.; pecíolo castanho-escuro a negro, brilhante, $9-23 \mathrm{~cm}$ compr., base com escamas lanceoladas, basefixas, castanho-escura; lâmina 1-2-pinada, 40-50 × 5-6 $\mathrm{cm}$, com tricomas glandulares na superfície abaxial, ca. 1-3 mm compr., secretores de cera branca ou amarelada; raque castanho-escura, brilhante; pinas com 2-3 pínulas, ascendentes; pínulas inteiras, linearlanceoladas a oblongo-lanceoladas, 4-5 × 0,7-0,8 $\mathrm{cm}$, margens serreadas, as distais inteiras, lineares ou lanceoladas, ascendentes; nervuras 2-4 furcadas; esporângios curto-pedicelados.

Material examinado: próximo à lagoa, 30-I-2004, G.A. Nóbrega et al. 12 (UNBA); idem, 4-III-2004, G.A. Nóbrega et al. 37 (UNBA).

Distribuição geográfica: Estados Unidos da América (sul da Flórida), México, América Central, Grandes Antilhas, Colômbia, Venezuela, Equador, Peru, Bolívia, Paraguai, Uruguai, Chile, Norte da Argentina e Brasil (PE, DF, RJ, SP, PR).

Distingüe-se pela lâmina 1-2-pinada, com 2-3 pínulas ascendentes. De acordo com Moran (1995a), o epíteto específico trifoliata, referente às pinas, não é um nome adequado, uma vez que podem ser encontradas pinas com 1-7 pínulas, sendo a condição mais comum 2-pinada. Pode ser encontrada em áreas de campo, abertas, crescendo entre gramíneas.
Pleopeltis Humb. \& Bonpl. ex Willd., Sp. Pl. 5: 211. 1810. Tipo: Pleopeltis angusta Humb. \& Bonpl. ex Willd.

Plantas epífitas, raramente rupícolas. Caule longo-reptante, ramificado, com escamas concolores a bicolores, peltadas, lanceoladas, raramente clatradas, margem freqüentemente irregular, inteira, fimbriada ou erodida, superfície pilosa ou glabra. Frondes pequenas, simples; pecíolo articulado com o caule; lâmina cartácea a coriácea, revestida densamente ou esparsamente por escamas peltadas, circulares a oval-lanceoladas; venação areolada (raramente aberta), aréolas com 1-3 vênulas livres inclusas. Soros arredondados a oblongos, surgindo entre as aréolas costais, recobertos com escamas arredondadas, peltadas ao menos no soro imaturo, com uma fileira de soros a cada lado da costa, na junção da maioria das vênulas inclusas, proeminentes; esporângios glabros, com ânulo vertical interrompido pelo pedicelo; esporos aclorofilados, monoletes.

De acordo com Lorea-Hernández (1995), o gênero apresenta aproximadamente 11 espécies neotropicais, sendo essencialmente Americano, com apenas uma espécie tropical Pleopeltis macrocarpa (Willd.) Kaulf.. O México constitui um centro de diversidade importante com a maioria das espécies.

Chave para as espécies de Pleopeltis

1. Lâmina inteira; soros alongados (comprimento 2 vezes maior que a largura) ............. P. astrolepis

1. Lâmina dividida; soros arredondados ou oblongos (comprimento até uma vez maior que a largura)

2. Lâmina pinatissecta; escamas apenas na costa . P.polypodioides

2. Lâmina subdicotomicamente dividida; escamas por toda a superfície adaxial .... P. pleopeltifolia

Pleopeltis astrolepis (Liebm.) E. Fourn., Mexic. Pl. 1: 87. 1872 = Polypodium astrolepis Liebm., Kongel. Daske Vidensk. Selk. Naturvidensk. Math. Afh. Ser. 2, 1: 185. 1849. Lectótipo: designado por A. R. Sm., Fl. Chiapas 2: 177. 1981: MÉXICO. Oaxaca: Trapiche de la Concepción, 1841, Liebmann s.n. (GH, n.v.).

Figura 5 E-F

Plantas epífitas. Caule horizontal, verde, longoreptante, ca. $1 \mathrm{~mm}$ diâm, com escamas arredondadas a deltóides, clatradas, peltadas, bicolores, com centro 


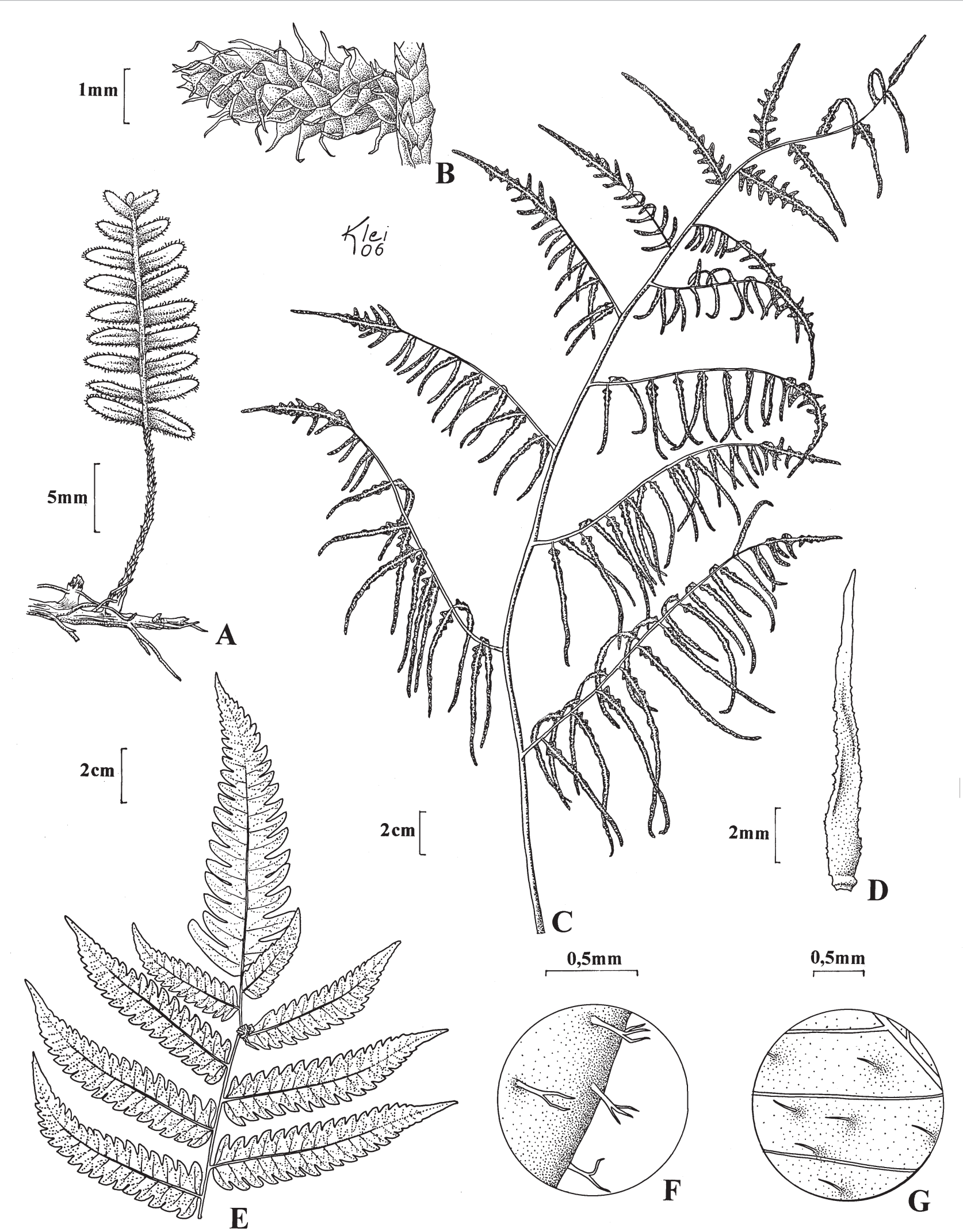

Figura 6. A-B. Pleopeltis polypodioides. A. Hábito. B. Detalhe da superfície abaxial da lâmina revestida densamente por escamas. C-D. Polybotrya goyazensis. C. Parte de uma fronde fértil. D. Escama do caule. E-G. Thelypteris biformata. E. Porção distal da lâmina estéril. F. Detalhe dos tricomas estrelados sobre a raque. G. Detalhe dos tricomas simples entre as nervuras, na superfície adaxial da lâmina. 
castanho-escuro, margem hialina e fimbriada, ca. 0,5 mm compr. Frondes monomorfas, simples, 8-17 cm compr.; pecíolo castanho-escuro, sulcado na superfície adaxial, $1-2 \times 0,1 \mathrm{~cm}$, alado, com escamas arredondadas a deltóides (estreladas), castanhoescuras, peltadas, margem denticulada, ca. $0,5 \mathrm{~mm}$ compr.; lâmina inteira linear-lanceolada, $6-15 \mathrm{~cm}$ compr., com escamas arredondadas a deltóides, bicolores, centro castanho, margem hialina e fimbriada, em ambas as faces da lâmina, peltadas, 0,2-0,5 mm compr.; nervuras totalmente imersas, anastomosadas com poucas vênulas livres inclusas. Soros alongados, duas vezes mais compridos que largos, surgindo em sulco na lâmina foliar, paralelos à costa, com paráfises de escamas fimbriadas, castanhas, margem hialina e centro mais espesso.

Material examinado: final da área de brejo, lado direito, 9-VI-2005, G.A. Nóbrega \& M. Andrade 100 (SP).

Distribuição geográfica: México até o Panamá, Colômbia até Guianas, sul da Bolívia e Brasil (PE, AL, BA, MG, RJ, SP, PR, SC)

De acordo com Tryon \& Stolze (1993), esta espécie pode ser separada das outras mais relacionadas por possuir escamas circulares e soros alongados (2-4 vezes mais compridos que largos). Foi encontrada em ambiente paludoso, crescendo como epífita.

Pleopeltis pleopeltifolia (Raddi) Alston, Bol. Soc. Broter., Ser. 2, 30: 21. 1956 = Polypodium pleopeltifolium Raddi, Opusc. Sci. Bol. 3(5): 286. 1819. Lectótipo: designado por Pichi Sermolli \& Bizarri, Webbia 60(1): 96, fig. 16. 2005: "Brasília, Raddi s.n". (PI, n.v.).

Figura 5 G-H

Plantas epífitas. Caule curto-reptante, ca. 3-4 mm diâm., revestido por escamas lanceoladas, castanhoescuras a negras, com margens hialinas, levemente fimbriadas, $2-3 \mathrm{~mm}$ compr. Frondes monomorfas, 21-36 cm compr.; pecíolo castanho-escuro a negro, 4-7 $\times 0,1 \mathrm{~cm}$, alado ao menos na porção superior, sulcado adaxialmente, com escamas peltadas, oblongolanceoladas a deltóides, margens denticuladas; lâmina subdicotomicamente dividida, 12-18,5 cm compr., adaxialmente com escamas oblongo-lanceoladas, castanho-escuras, margens fimbriadas e hialinas, ca. $1 \mathrm{~mm}$ compr.; segmentos lineares, $6-8 \times 0,2-0,5 \mathrm{~cm}$; nervuras anastomosadas, com 1-2 vênulas inclusas nas aréolas. Soros oblongos, medianos.
Material examinado: trilha de acesso à lagoa, 30-I-2004, G.A. Nóbrega et al. 5 (UNBA); entre os marcos 90 e 89 da trilha de visitação, 4-III-2004, G.A. Nóbrega et al. 47 (UNBA); mata de brejo junto ao Córrego Vargem Limpa (Paliteiro), 22²0'29”S, 4900'90”'W, 303 m, 30-III-2006, J. Prado et al. 1645 (SP).

Distribuição geográfica: Uruguai e Brasil (CE, BA, GO, ES, MG, MT, SP, PR, SC, RS).

Pode ser facilmente reconhecida pela lâmina subdicotomicamente dividida, com escamas oblongolanceoladas, castanho-escuras, margens fimbriadas e hialinas na superfície adaxial, e ainda pelos soros oblongos, medianos, entre a margem e a costa. Pleopeltis pleopeltifolia pode ser confundida com $P$. angusta Humb. \& Bonpl., porém esta última diferenciase por possuir as escamas do caule pilosas adaxialmente e ocorre apenas no México e Mesoamérica. Na área do JBMB, pode ser encontrada na Floresta Estacional Semidecidual Submontana, na Floresta Estacional Semidecidual Aluvial (mata de brejo) e na Savana Estacional Florestada (Cerradão).

Pleopeltis polypodioides (L.) E.G. Andrews \& Windham, Contr. Univ. Michigan Herb. 19: 46. $1993 \equiv$ Acrostichum polypodioides L., Sp. Pl. 2: 1068. 1753. Síntipo: Plukenet, Phytogr. tab. 289, fig. 1. 1694.

Figura 6 A-B

Plantas epífitas. Caule longo-reptante, ca. $1 \mathrm{~mm}$ diâm., revestido por escamas lanceoladas, peltadas, castanhas, ca. $2 \mathrm{~mm}$ compr. Frondes monomorfas, eretas, 2,5-5,5 × 1-1,5 cm; pecíolo castanho-claro, segregado, sulcado na superfície adaxial, ca. $0,5 \mathrm{~mm}$ diâm., revestido por escamas oblongas a lanceoladas, castanhas, margens hialinas, peltadas, ca. $1 \mathrm{~mm}$ compr.; lâmina deltóide a lanceolada, pinatissecta, cartácea, revestida por escamas na superfície abaxial, ovais a arredondadas na base, aguda no ápice, margem inteira, superfície adaxial glabra, costa com escamas; segmentos adnados, patentes a agudos, aproximadamente elípticos; nervuras ocultas. Soros arredondados, próximos à margem da lâmina, os jovens protegidos por escamas sobrepostas entre si, similares às da lâmina.

Material examinado: marco 78 da Trilha de Visitação, 4-III-2004, G.A. Nóbrega et al. 45 (UNBA).

Distribuição geográfica: parte meridional da América do Sul. No Brasil: DF, MG, RJ, SP, PR. 
Esta espécie foi retirada de Polypodium devido às características do indumento presente nos soros jovens. Este é constituído de escamas peltadas, similares às encontradas no tecido foliar, uma característica de Pleopeltis. Pode ser caracterizada pela presença de indumento escamoso somente na face abaxial da lâmina, pelas frondes pequenas (menos de $10 \mathrm{~cm}$ de compr.), espaçadas entre si, eretas, pinatissectas e dispostas sobre um caule longo-reptante e delgado. Este táxon é tratado por Sota (2003) como Pleopeltis squalida (Vell.) de la Sota. Porém, há dúvidas se o nome atribuído por Vellozo (Polypodium squalidum Vell.) foi validamente publicado e por este motivo o epíteto não foi adotado no presente trabalho. Cresce preferencialmente como epífita, porém também pode ser encontrada como rupícola. No JBMB foi encontrada na Floresta Estacional Semidecidual Submontana e na Floresta Estacional Semidecidual Aluvial (mata de brejo), em ambiente sombreado, crescendo somente como epífita.

Polybotrya Willd., Sp. Pl. 5: 99. 1810. Tipo: Polybotrya osmundacea Willd.

Plantas hemiepífitas, terrestres ou ocasionalmente rupícolas. Caule escandente, curto a longo-reptante, delgado a massivo, ca. 1-3 cm diâm., com densa cobertura de escamas e poucas a muitas raízes fibrosas longas, em seção transversal, com 4-10 meristelos dispostos circularmente, cada um circundado por uma bainha escura esclerenquimática. Frondes estéreis e férteis fortemente dimorfas, a fértil geralmente com maior complexidade que a estéril e com segmentos muito reduzidos; lâmina estéril pinada a 3-pinadopinatífida, lâmina fértil geralmente 2-4-pinada, raramente pinado-pinatífida, glabra, pubescente a pouco escamosa; venação aberta ou areolada, sem nervuras livres inclusas. Soros acrosticóides; indúsio ausente; esporângios recobrindo toda a superfície abaxial dos segmentos, quase sempre sobre as margens e algumas vezes também sobre a superfície adaxial, com ânulo vertical incompleto, interrompido pelo pedicelo, paráfises ausentes ou presentes; esporos equinados, monoletes.

Polybotrya é um gênero neotropical com 35 espécies (Mickel \& Smith 2004), sendo mais diverso nos Andes, onde são encontradas 23 espécies (Moran 1995b).

Caracteriza-se pelas frondes fortemente dimorfas, pela seção transversal do caule com 4-10 meristelos dispostos circularmente, cada um rodeado por uma bainha escura esclerenquimática e pelo hábito geralmente hemiepífita (Moran 1995b). De acordo com Moran (1987), o gênero Polybotrya pode ser dividido em três subgêneros, Soromanes, Sorbifolia e Polybotrya. Na área do JBMB foi encontrada apenas uma espécie que se posiciona no subgênero Polybotrya, com fronde estéril decomposta (1-4-pinada), nervuras livres e hábito hemiepífita.

Polybotrya goyazensis Brade, Bradea 1: 24, tab. 1, fig. 1. 1969. Tipo: BRASIL. Goiás: Goiânia, floresta primária, XII-1936, A.C. Brade 15373 (holótipo $\mathrm{RB}$, n.v.; isótipo NY, n.v.).

Figura 6 C-D

Plantas hemiepífitas. Caule longo-reptante, escandente, ca. 1,3-1,5 cm diâm., densamente revestido por escamas castanho-escuras, translúcidas, linear-lanceoladas, ca. 0,5-1,5 cm compr., margens mais claras denticuladas a erodidas, base cordada ou irregularmente recortada em várias proporções, com um ponto de fixação escuro e esclerificado. Frondes dimorfas, fronde estéril 1,26-1,52 × 0,45-0,66 m, fronde fértil ca. $74 \times 24 \mathrm{~cm}$; pecíolo estramíneo, $30-44 \mathrm{~cm}$ compr., aproximadamente $1 / 2$ a $1 / 3$ do comprimento da fronde, com mais de 3 feixes vasculares na base; lâmina estéril 2-pinado-pinatífida, lanceolada a oval, cartácea, superfície adaxial glabra e superfície abaxial com tricomas aciculares, alvos, ca. 0,5-1 mm compr., tricomas glandulares avermelhados a castanhos ocasionalmente presentes, sésseis, resiníferos; pinas lanceoladas a deltóides, $25-32 \times 10-14 \mathrm{~cm}$, as supra-basais levemente pinatífidas; pínulas lanceoladas a deltóides, 6-9 × 1-2 $\mathrm{cm}$, arranjadas catadromicamente sobre a base, lado acroscópico ligeiramente prolongado, margem crenada esparsamente ciliada, com tricomas castanho-claros a alvos, aciculares, ca. $1 \mathrm{~mm}$ compr.; raque, costa e cóstula pubescentes, costa e cóstula abaxialmente com tricomas moderados a densos, castanho-claros a alvos, unicelulares, aciculares, ca. 0,5-1,0 mm compr., adaxialmente com tricomas castanho-avermelhados, diminutos, ca. 0,5 $\mathrm{mm}$ compr., mais densos no sulco adaxial., raque com tricomas castanho-avermelhados menores que $1 \mathrm{~mm}$, em ambas as faces, mais densos no sulco adaxial; lâmina fértil 2-pinada, lanceolada; pinas $11-20 \times 2,5-6 \mathrm{~cm}$; pínulas caudadas, com base lobada ou ondulada; venação aberta. Soros recobrindo ambas as superfícies da lâmina, com paráfises; esporângios pedicelados.

Material examinado: início da área de brejo, 21-V-2004, G.A. Nóbrega \& M. Andrade 73 (SP); 
área de brejo, lado esquerdo do córrego, acesso aos posseiros, 5-XI-2004, G.A Nóbrega \& M. Andrade 91 (SP); mata de brejo junto ao Córrego Vargem Limpa (Paliteiro), 22 20'29”S, 4900'90”W, 30-III-2006, J. Prado et al. 1638 (SP).

Distribuição geográfica: Paraguai e Brasil (PA, GO, DF, MT, SP).

De acordo com Moran (1987), Polybotrya goyazensis e P. caudata Kunze diferem das outras espécies do gênero pelos diminutos tricomas presentes na margem da lâmina. Entretanto, $P$. goyazensis distingüe-se de $P$. caudata por esta última apresentar as escamas do caule de coloração marrom, opacas, basefixas, com margens subinteiras e base curva e espessada.

Este constitui o primeiro registro desta espécie para o Estado de São Paulo, onde foi encontrada em ambiente paludoso, formando uma grande população na área do JBMB.

Polypodium L. Sp. Pl. 2: 1082. 1753. Tipo: Polypodium vulgare $\mathrm{L}$.

Plantas epífitas ou rupícolas, raramente terrestres. Caule horizontal curto a longo-reptante, moderadamente massivo a delgado, geralmente ramificado, com escamas peltadas a pseudopeltadas, clatradas ou não, superfície glabra ou pilosa, margem inteira ou denteada. Frondes monomorfas a levemente dimorfas (com a fértil maior que a estéril), agrupadas ou espaçadas entre si; pecíolo anguloso, sulcado, estramíneo, raramente escuro, articulado com o caule, com 1 feixe vascular na base; lâmina pinatífida, pinatissecta ou 1-pinada, com escamas gonfóides; venação aberta. Soros arredondados ou alongados, ocasionalmente elípticos, surgindo no ápice ou na junção das nervuras, ou geralmente em um receptáculo um pouco elevado, com ou sem paráfises; esporângios com ânulo vertical interrompido pelo pedicelo; esporos elipsoidais, monoletes.

$\mathrm{Na}$ área estudada, o gênero está representado por uma única espécie, Polypodium hirsutissimum, que pode ser facilmente reconhecida pela lâmina densamente revestida com escamas gonfóides.

Polypodium hirsutissimum Raddi, Opusc. Sci. Bol. 3: 286. 1819. Tipo: BRASIL. RIO DE JANEIRO: s.d., Raddi s.n. (holótipo PI, n.v.; isótipos BM, G, K, P, n.v).

Plantas epífitas. Caule longo-reptante, ca. 3-4 mm diâm., revestido por escamas castanho-avermelhadas, lanceoladas, margens ciliadas, ápice longamente acuminado, ca. 1-3 mm compr. Frondes monomorfas, eretas, 13-19 × 1,5-2,5 cm; pecíolo castanhoescuro, sulcado adaxialmente, ca. 1,0-2,5 ×0,1 cm, revestido por escamas castanhas, base arredondada a deltóide e ápice filiforme, margens ciliadas, 0,5-3,0 mm compr.; lâmina oblongo-lanceolada a linear lanceolada, atenuada em ambas extremidades, pinatissecta, subcoriácea, $11,5-15,5 \mathrm{~cm}$, revestida de escamas alvas, com ponto de fixação castanho-escuro, gonfóides (com base arredondada a deltóide e ápice filiforme), margens ciliadas, ca. $2 \mathrm{~mm}$ compr., na superfície adaxial e com escamas castanho-claras, com mesma forma e tamanho na superfície abaxial; raque revestida de escamas castanhas, lanceoladas, ápice longamente acuminado, margens ciliadas, 1-2 mm compr.; segmentos adnados, inseridos em ângulo reto na raque, oblongo-lancelolados, 1,0-1,2 × 0,3-0,4 $\mathrm{cm}$; venação oculta. Soros arredondados, próximos da costa, protegidos por escamas.

Material examinado: divisa com a Reserva Legal da Unesp, Cerrado, 2006, A.G. Faraco et al. 268 (UNBA); divisa com a Reserva Legal da Unesp, Cerrado, a ca. $1 \mathrm{~m}$ de altura no forófito, 31-III-2006, A.G. Faraco \& M. Carboni 189 (UNBA).

Distribuição geográfica: Paraguai, Uruguai, Argentina e Brasil (BA, MG, RJ, MT, SP, PR, SC, RS).

Conforme Prado \& Labiak (2003) esta espécie caracteriza-se pelas frondes eretas, revestidas por indumento de escamas. Polypodium hirsutissimum também pode ser terrestre ou rupícola, porém na área de estudo foi encontrada apenas como epífita, a condição mais comum.

Pteridium Scopoli, Fl. carniol. ed. 1: 169. 1760, nom. cons. Tipo: Pteris aquilina L. (= Pteridium aquilinum (L.) Kuhn).

Plantas terrestres. Caule longo-reptante, subterrâneo, piloso. Frondes eretas, monomorfas; pecíolo longo, porção basal com tricomas curtos e mais de três feixes vasculares; lâmina 2-4-pinado-pinatífida, deltóide a oblongo-deltóide, coriácea, com pina terminal conforme; últimos segmentos variáveis em número e forma, subopostos a alternos, com margem sempre revoluta, peciolados; venação aberta. Soros marginais e usualmente contínuos; indúsio abaxial, rudimentar, fimbriado, formado pela margem da lâmina curvada e modificada; esporângios sobre uma comissura vascular, vertical e interrompido pelo pedicelo; esporos triletes. 
O gênero pode ser tratado como uma única e ampla espécie, com variedades regionais (Tryon 1941), ou como várias espécies distintas (Mickel \& Smith 2004), como foi adotado neste trabalho. As plantas geralmente crescem agressivamente, invadindo áreas perturbadas. São muito comuns em pastagens, campos cultivados e margens de estradas. Pteridium é distinguido pelo caule posicionado abaixo da superfície do solo, com tricomas, pelas frondes coriáceas, indúsio abaxial, vestigial, e esporos triletes (Mickel \& Beitel 1988).

Pteridium arachnoideum (Kaulf.) Maxon, J. Wash. Acad. Sci. 14: 89. 1924 = Pteris arachnoidea Kaulf., Enum. Fil.: 190. 1824. Tipo: BRASIL. Sem localidade, s.d., Chamisso s.n. (holótipo LE, n.v.).

Plantas terrestres. Caule revestido por tricomas aciculares, castanho-escuros, com 2-5 mm compr. Frondes monomorfas, 1,5-3,1 m compr., grandes, eretas ou escandentes; pecíolo amarelo a pardo, 0,6-1,2 m compr., glabro e sulcado na superfície adaxial; lâmina deltóide, 3-pinado-pinatissecta, coriácea, tricomas pardos a castanho-claros, longos e tortuosos na superfície abaxial; raque adaxialmente sulcada, amarelo-avermelhada e glabra; pinas opostas, 2-pinado-pinatissecta; pínulas de primeira ordem 1-pinado-pinatissecta; pínulas de segunda ordem com segmentos deltóides ou lanceolados 1-3 cm compr.; raque de segunda ordem lobada; nervuras 1-furcadas, com tricomas sobre as nervuras abaxiais.

Material examinado: área abaixo dos fios da torre de alta tensão, próximo à area da Unesp, 4-III-2004, G.A. Nóbrega et al. 36 (UNBA).

Distribuição geográfica: América Central, Antilhas, Colômbia, Venezuela, Guiana, Suriname, Guiana Francesa, Trinidad, Equador, Peru, Bolívia, Paraguai, Norte da Argentina e Brasil (AM, PE, AL, MT, BA, MG, RJ, SP, SC, RS).

Pode ser reconhecida pelas frondes grandes, com até $3 \mathrm{~m}$ de compr., lâmina coriácea e raque de segunda ordem lobada (Prado 2004d). Cresce em áreas abertas e devastadas, inclusive nas bordas de florestas, formando grandes populações. Na área do JBMB foi encontrada na borda da Floresta Estacional Semidecidual Submontana e em toda a área de campo, perturbada pela ação do fogo, crescendo em pleno sol.

Salpichlaena Hook., Gen. Fil. tab. 93. 1842. Tipo: Blechnum volubile Kaulf. (= Salpichlaena volubilis (Kaulf.) Hook.).
Plantas terrestres, trepadeiras. Caule longoreptante a curto-reptante, delgado a moderadamente robusto, com escamas castanho-escuras a negras, às vezes com margens mais claras. Frondes escandentes, monomorfas a parcialmente dimorfas (a pina fértil com segmentos mais estreitos que os da pina estéril); lâmina 2-pinada, imparipinada, glabra; raque volúvel, até $15 \mathrm{~m}$ compr., às vezes com tricomas curtos; pinas alternas, imparipinadas; pínulas ou últimos segmentos inteiros a serreados no ápice, às vezes com escamas esparsas; venação aberta, conectadas a uma nervura marginal. Soros alongados, em ambos os lados da costa, sobre comissura vascular; indúsio linear, tubular, partindose em fragmentos irregulares; esporângios com ânulo vertical, interrompido pelo pedicelo; esporos aclorofilados, monoletes.

Este é um gênero neotropical com cerca de três espécies (Moran 1995c). Pode ser identificado pelo hábito trepador e pelos soros alongados em ambos os lados da costa.

Salpichlaena volubilis (Kaulf.) J. Sm. in Hook. \&

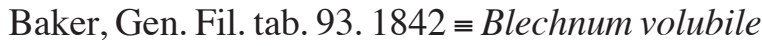
Kaulf., Enum. Fil.: 159. 1824. Tipo: BRASIL. Sem localidade, s.d., Chamisso s.n. (LZ, destruído).

Caule longo-reptante, ca. 9 mm diâm., com escamas lanceoladas, castanho-escuras, margens mais claras, 2-3 mm compr. Frondes monomorfas, com crescimento indeterminado; pecíolo estramíneo, sulcado adaxialmente, ca. 2 mm diâm., com escamas castanhas, lanceoladas a deltóides, 3-4 mm compr.; lâmina na fase terrestre 1-pinada; pinas oblongolanceoladas, 14-15 cm compr., base levemente inequilateral e ápice acuminado a caudado; lâmina na fase trepadeira, 2-pinada, cartácea a subcoriácea, tecido laminar glabro em ambas as faces; raque muito longa, escandente, estramínea, ca. $1 \mathrm{~mm}$ diâm., com escamas castanhas esparsas, ca. $1 \mathrm{~mm}$ compr.; pinas 1-pinadas, 2-3 pares de pínulas, 13-16 cm compr.; pínulas inteiras, oblongo-lanceoladas, alternas a subopostas, pecioluladas, 6-8 cm compr., base arredondada, levemente inequilateral, ápice acuminado a caudado, margens cartilaginosas, inteiras a crenuladas no ápice; costa sulcada adaxialmente, com escamas castanhas, esparsas, tanto na superfície abaxial quanto na adaxial, ca. 0,5 mm compr.; raquíola semelhante à raque na forma e indumento; venação aberta, nervuras simples ou furcadas, paralelas entre si. Soros alongados, justapostos à costa; indúsio inteiro a lacerado; esporângios persistentes. 
Material examinado: cachoeira do lago do Zoológico, divisa com a Reserva Legal da Unesp e com o Jardim Zoológico, 31-V-2006, M.C. Carboni et al. 415 (SP, UNBA); mata paludosa, margem do Córrego Vargem Limpa, 31-V-2006, M.C. Carboni et al. 416 (SP, UNBA).

Distribuição geográfica: América Central, Pequenas Antilhas, Colômbia, Venezuela, Guiana, Guiana Francesa, Equador, Peru, Bolívia, Paraguai e Brasil (AM, CE, PE, BA, MT, MG, RJ, SP, SC).

Salpichlaena volubilis caracteriza-se pelo hábito escandente, pelas pínulas com margens cartilaginosas e ápice acuminado a caudado e pelas pínulas férteis estreitas. As espécies jovens são terrestres, sendo o hábito de trepadeira alcançado no decorrer do desenvolvimento da planta. Pode ser encontrada na área estudada, na Floresta Estacional Semidecidual Aluvial, em ambiente sombreado.

Serpocaulon A.R. Sm., Taxon 55(4): 924. 2006. Tipo: Polypodium loriceum L. (= Serpocaulon loriceum (L.) A.R. Sm.).

Plantas epífitas ou rupícolas, raramente terrestres. Caule horizontal curto a longo-reptante, geralmente ramificado, com escamas peltadas, clatradas, superfície glabra, margem inteira ou denteada. Frondes monomorfas, articuladas, sobre um filopódio curto, agrupadas ou espaçadas entre si; pecíolo cilíndrico, anguloso, sulcado, estramíneo, com 1 feixe vascular na base; lâmina pinatífida, pinatissecta ou 1-pinada, glabra ou pubescente, com tricomas hialinos e com escamas esparsas, lineares, clatradas; venação areolada, gonioflebóide, com uma nervura livre inclusa em cada aréola. Soros arredondados, com ou sem paráfises; esporângios com ânulo vertical interrompido pelo pedicelo; esporos elipsoidais, monoletes.

Serpocaulon difere de Polypodium, gênero do qual foi segregado, por este apresentar venação aberta e lâmina com escamas gonfóides. De acordo com Smith et al. (2006), Serpocaulon ocorre em regiões tropicais e subtropicais, principalmente na América do Sul, enquanto Polypodium ocorre em regiões temperadas do hemisfério Norte, México e Mesoamérica.

Chave para as espécies de Serpocaulon

1. Caule sulcado e com cera branca; lâmina glabra . S. catharinae

1. Caule não sulcado; lâmina pubescente, com tricomas hilanos e escamas filiformes castanhoavermelhadas S. vacillans
Serpocaulon catharinae (Langsd. \& Fisch.) A.R. Sm., Taxon 55(4): 928. 2006 = Polypodium catharinae Langsd. \& Fisch., Ic. Fil.: 9. tab. q. 1810. Lectótipo: designado por Hensen, Nova Hedwigia $50(3,4)$ : 292. 1990: "Habitat in insula Sanctae Catharinae Brasiliae" (LE, n.v.).

Plantas epífitas. Caule sulcado, longo-reptante, ca. 4-5 mm diâm., com cera branca, revestido por escamas bicromáticas, margem hialina, fimbriada e centro castanho-escuro, base arredondada e ápice longamente acuminado a filiforme, ca. 3-5 $\times 1 \mathrm{~mm}$. Frondes monomorfas, $31-33 \times 6,5-9,5 \mathrm{~cm}$, distantes entre si ca. 4-10 mm; pecíolo castanho, 10-11 ×0,1-0,2 $\mathrm{cm}$, adaxialmente sulcado, glabro; lâmina deltóide a lanceolada, pinatissecta, $20-23 \mathrm{~cm}$ compr., cartácea a subcoriácea; segmentos linear-lanceolados, ca. 3-5 × $0,7-0,8 \mathrm{~cm}$, margem inteira, alargados junto à raque, glabros, segmentos medianos e distais levemente arqueados para o ápice a patentes, segmentos proximais voltados para a base; venação areolada, com uma fileira de aréolas entre a costa e a margem, com uma vênula de ápice espessado inclusa em cada aréola, margem da lâmina com nervuras livres de ápice expandido. Soros inframediais, dispostos em uma fileira, no ápice das vênulas inclusas nas aréolas.

Material examinado: área próxima à região invadida, 9-VI-2005, G.A. Nóbrega \& M. Andrade 103 (SP).

Distribuição geográfica: Paraguai e Brasil (PE, MG, RJ, SP, PR, SC, RS).

Pode ser reconhecida pelo caule com cera branca, escamas bicromáticas e pela distância entre as frondes de 4-10 mm. No JBMB foi encontrada na Savana Estacional Florestada (Cerradão), na área dos posseiros, e também na Floresta Estacional Semidecidual Submontana.

Serpocaulon vacillans (Link) A.R. Sm., Taxon 55(4): 929. 2006 三 Polypodium vacillans Link, Hort. Berol. 2: 97. 1833. Tipo: "Brazil, s.d., s.col. (holótipo B, n.v.).

Plantas terrestres. Caule não sulcado, longoreptante, 4-5 mm diâm., sem cera branca, coberto por escamas clatradas, oblongo-lanceoladas, castanhas, peltadas, ca. $3 \mathrm{~mm}$ compr. Frondes monomorfas, eretas, 0,67-1,32 m compr.; pecíolo amarelo-claro, $20-42 \times 0,2-0,3 \mathrm{~cm}$, com escamas na porção basal iguais às do caule; lâmina lanceolada, 34- $95 \mathrm{~cm}$ compr., pinatissecta, cartácea; raque amarelo-clara, com tricomas aciculares hialinos esparsos e escamas 
lineares, clatradas, castanho-avermelhadas, sulcada ou não na superfície adaxial; segmentos medianos linearlanceolados, ca. $13 \times 1,5 \mathrm{~cm}$; venação anastomosada, 2-3 séries de aréolas, com uma vênula de ápice espessado incluída em cada aréola. Soros inframediais, arredondados, dispostos em mais de uma fileira entre a margem e a costa, sobre as vênulas inclusas nas aréolas, com paráfises.

Material examinado: trilha de Acesso à Lagoa, 30-I-2004, G.A. Nóbrega et al. 4 (UNBA); marco 59 da trilha de visitação, 4-III-2004, G.A. Nóbrega et al. 43 (UNBA); à direita do córrego Vargem Limpa, 17-V-2004, G.A. Nóbrega \& M. Andrade 69 (UNBA); mata de brejo junto ao Córrego Vargem Limpa (Paliteiro), 22 20'29"S, 4900'90"W, 30-III-2006, J. Prado et al. 1632 (SP).

Distribuição geográfica: México a Bolívia, Antilhas (Cuba, Hispaniola, Jamaica, Montserrat, República Dominicana) Paraguai, Argentina, Brasil (BA, MG, RJ, SP, PR, SC, RS).

Caracteriza-se pelo pecíolo amarelo-claro, com escamas na base iguais às do caule, clatradas, oblongolanceoladas, castanhas, peltadas, margens com várias fileiras de células hialinas, e pela raque com tricomas hialinos e escamas castanho-avermelhadas. Pode ser encontrada em todas as formações florestais presentes na reserva do JBMB.

Sticherus C. Presl, Tent. Pter.: 51. 1836. Lectótipo: designado por Christensen, Ind. Fil.: LIV. 1906: Mertensia laevigata Willd. (= Sticherus laevigatus (Willd.) C. Presl).

Plantas terrestres. Caule decumbente, longoreptante, escamoso. Frondes monomorfas, escandentes ou eretas, várias vezes furcadas; pecíolo escamoso; ramos basais das furcas com ou sem segmentos pectinados; gemas axilares protegidas por indumento de escamas, com ou sem pseudoestípulas; pinas bifurcadas pseudodicotomicamente; últimos ramos pectinados, variando de pinatissectos a pinatífidos, com escamas e tricomas; venação aberta. Soros com 3-6 esporângios; esporângios sésseis com ânulo oblíquo não interrompido pelo pedicelo; esporos aclorofilados, monoletes.

O gênero apresenta ca. de 90 espécies, com 40 delas ocorrendo na América Tropical, sendo comum a ocorrência de híbridos (Østergaard-Andersen \& Øllgaard 2001). Pode ser distingüido de Dicranopteris pelo padrão de indumento formado por escamas e tricomas e pelas escamas que recobrem as gemas nas pseudodicotomias (Prado 2004c).
Sticherus bifidus (Willd.) Ching, Sunyatsenia 5: 282. $1940 \equiv$ Mertensia bifida Willd., Kongl. Vetensk. Acad. Nya Handl. 25: 168. 1804. Tipo: VENEZUELA. Sem localidade, s.d., Bredemeyer s.n. (holótipo Herb. Willd. 19.468, B, n.v.).

Plantas terrestres. Rizoma longo-reptante, ca. 3-4 mm diâm., com escamas esparsas, castanho-escuras, margens denticuladas, ca. $4 \times 1 \mathrm{~mm}$. Frondes ca. 87-88 cm compr., eretas quando jovens e escandentes quando adultas; pecíolo castanho-escuro, ca. 45-48 × 0,2 cm, porção basal com escamas semelhantes às do rizoma e distalmente com escamas castanho-claras, longociliadas nas margens e tricomas alvos tortuosos a filiformes; pinas 1-2-furcadas, desprovidas de pinas acessórias na base de cada furca; pseudoestípulas presentes ou ausentes; gemas com escamas castanho-avermelhadas ca. $3 \mathrm{~mm}$ compr., margens longo-ciliadas; ramo abaixo da furca com segmentos pectinados, pinatissectos, 5-7 × 1,5-2 mm; últimos ramos pectinados, pinatissectos, $8-12 \times 0,5-1,5 \mathrm{~cm}$, geralmente mais largos na porção basal; segmentos ca. 1-1,5 × 0,2-0,3 cm, cartáceos, adaxialmente glabros e abaxialmente tomentosos, com tricomas castanho-claros a alvos, tortuosos, costas com escamas castanho-claras, margens longo-ciliadas; nervuras simples a 1-furcadas. Soros medianos.

Material examinado: próximo à lagoa, 17-V-2004, G.A. Nóbrega \& M. Andrade 66 (UNBA).

Distribuição geográfica: sul do México, América Central, Antilhas, Colômbia, Venezuela, Guiana, Trinidad, Equador, Peru, Bolívia, Paraguai e Brasil (CE, BA, MT, GO, MG, RJ, SP, PR, SC, RS).

Caracteriza-se pelo indumento formado de tricomas e escamas, estes de coloração castanho-clara a alvos, na face abaxial das frondes (Prado 2004c). Cresce junto com Dicranopteris flexuosa e ambas formam grandes populações na área aberta do JBMB, próxima à lagoa.

Thelypteris Schmidel, Icon. pl. (ed. Keller): 45, tab. II. 1763. nom. cons. Tipo: Acrostichum thelypteris L. (= Thelypteris palustris Schott).

Plantas terrestres ou rupícolas. Caule reptante a ascendente ou ereto. Frondes monomorfas ou dimorfas; pecíolo desprovido de estípulas, não articulado com o caule, com dois feixes vasculares na base; lâmina geralmente 1-pinada a 1-pinado-pinatissecta, pinas proximais reduzidas, gradualmente, abruptamente ou não reduzidas; raque com ou sem escamas; pinas inteiras ou profundamente pinatissectas, sésseis ou curto- 
pecioluladas; costa sulcada adaxialmente; gemas ausentes ou presentes na axila das pinas; aeróforos ausentes ou presentes na base das pinas proximais; venação aberta ou areolada; indumento variado, freqüientemente formado por tricomas simples (aciculares, uncinados, furcados, setiformes, pluricelulares), ramificados (furcados ou estrelados), menos frequente com tricomas glandulares, principalmente sobre pecíolo, raque, costa e tecido laminar; escamas presentes ou ausentes sobre a raque e a costa. Soros arredondados, oblongos ou ao longo das nervuras, comumente inframedial ou supramedial; indúsio peltado, reniforme a reniformearredondado, grande (ca. $1 \mathrm{~mm}$ diâm.) e persistente ou pequeno (menos que $0,3 \mathrm{~mm}$ diâm.), às vezes ausentes; esporângios glabros ou com tricomas na cápsula ou no pedicelo, ânulo vertical interrompido pelo pedicelo; esporos aclorofilados, monoletes.

Thelypteris possui cerca de 1.000 espécies pantropicais, com poucas espécies de áreas temperadas, e aproximadamente 300 espécies neotropicais. O gênero diferencia-se pelo pecíolo com dois feixes vasculares, pelos tricomas aciculares sobre várias partes da fronde e pelos esporos bilaterais com perisporo proeminente (Mickel \& Smith 2004). Segundo a classificação adotada pelos mesmos autores, Thelypteris é composto por sete subgêneros: Amauropelta, Cyclosorus, Steiropteris, Goniopteris, Meniscium, Thelypteris e Stegnogramma. Neste trabalho foram encontrados quatro subgêneros: Amauropelta, Cyclosorus, Goniopteris e Meniscium.

Chave para as espécies de Thelypteris

1. Lâmina 1-pinada; venação areolada, meniscióide ( subg. Meniscium)

2. Margens das pinas serreadas; 8-14 pares de nervuras secundárias; esporângios com pedicelos glabros T. serrata

2. Margens das pinas subinteira a crenulada; $17-18$ pares de nervuras secundárias; esporângios com tricomas no pedicelo T. longifolia

1. Lâmina 1-pinado-pinatífida ou 1-pinado-pinatissecta; venação aberta ou apenas as nervuras proximais de segmentos adjacentes anastomosadas (não meniscióide)

3. Indumento formado por tricomas estrelados, entre outros; gemas presentes adaxialmente nas axilas das pinas distais (subg. Goniopteris) T. biformata

3. Indumento desprovido de tricomas estrelados; gemas ausentes ou pouco desenvolvidas

4. Pinas proximais menores que as medianas, gradualmente ou abruptamente reduzidas, com nervuras proximais de segmentos adjacentes unindo-se à margem acima do sinus

5. Tricomas glandulares ausentes no tecido lâminar e/ou nervuras, costas e margens

6. Esporângios setosos; tricomas uncinados presentes no pecíolo. (subg. Amauropelta)

6. Esporângios glabros; tricomas uncinados ausentes no pecíolo T. heineri

5. Tricomas glandulares presentes nas pinas, no tecido laminar e/ou nervuras, costas e margens

7. Caule subereto a ereto; escamas do caule glabras

T. eriosora

7. Caule curto ou longo-reptante; escamas do caule pilosas em toda extensão ou apenas nas margens

8. Pinas proximais gradualmente reduzidas; tricomas uncinados presentes no tecido laminar e margens T. rivularioides

8. Pinas proximais abruptamente reduzidas; tricomas uncinados ausentes .......... T. mosenii

4. Pinas proximais maiores, ou do mesmo tamanho das medianas, ou reduzidas, com nervuras proximais de segmentos adjacentes unindo-se no sinus ou abaixo deste .............. (subg. Cyclosorus)

9. Pecíolo desprovido de escamas na base; pinas curto-pecioluladas T. interrupta

9. Pecíolo com escamas na porção basal; pinas sésseis

10. Raque pubescente na superfície abaxial, glabra na superfície adaxial; nervuras proximais de segmentos adjacentes unindo-se abaixo do sinus a uma nervura excurrente T. hispidula

10. Raque densamente pubescente em ambas as superfícies; nervuras proximais de segmentos adjacentes unindo-se no sinus T. conspersa 
Thelypteris biformata (Rosenst.) R.M. Tryon, Rhodora 69: 5. $1967 \equiv$ Dryopteris biformata Rosenst., Repert. Spec. Nov., Regni Veg. 7: 300. 1909. Tipo: PERU. SAN Martin: pr. Tarapoto, ad rivulum Cachi-yacu, s.d., R. Spruce 4037 (holótipo P, n.v.; isótipos BM, K, n.v.; fragmento US, n.v.).

Figura 6 E-G

Plantas terrestres. Caule curto-reptante, ca. $8 \mathrm{~mm}$ diâm., com escamas aciculares a filiformes, ferrugíneas, 1-2 mm compr. e escamas linear-lanceoladas, castanho-escuras no ápice. Frondes monomorfas, 0,96-1,5 m compr.; pecíolo com metade ou mais que o comprimento da fronde, $61-82 \times 0,3-0,4 \mathrm{~cm}$, com tricomas estrelados densos $0,1-0,3 \mathrm{~mm}$ compr., base com escamas linear-lanceoladas iguais às do rizoma; lâmina 1-pinado-pinatífida, cartácea a subcoriácea, com ápice pinatífido ou mais ou menos similar às pinas laterais, pinas proximais maiores ou do mesmo tamanho das medianas, truncada na base; raque com vários tipos de tricomas, os aciculares com ca. $1 \mathrm{~mm}$ compr. e os furcados e estrelados, mais densos, com 0,1-0,3 mm compr.; pinas 8-17 pares, 4-12 × 0,9-2,5 $\mathrm{cm}$, curto-pecioluladas, peciólulo ca. $2 \mathrm{~mm}$ compr.; segmentos 0,5-1,3 × 0,2-0,4 cm, ápice arredondado ou truncado; aeróforos discretos presentes na base das pinas proximais, abaxialmente; gemas presentes adaxialmente, nas axilas das pinas distais; venação aberta, 6-12 pares de nervuras por segmento, com nervuras proximais de segmentos adjacentes unindose à margem acima do sinus; indumento abaxial de tricomas aciculares, 0,3-1 mm compr., nas costas, nervuras e tecido laminar, costas também com tricomas furcados 0,2-0,3 mm compr., superfície adaxial com tricomas aciculares, adpressos, 0,1-0,4 mm compr., entre as nervuras. Soros inframedianos; indúsios castanhos, pubescentes, com tricomas mais longos que os esporângios; esporângios com tricomas no pedicelo.

Material examinado: no barranco do córrego, área de brejo, 21-V-2004, G.A. Nóbrega \& M. Andrade 79 (UNBA); idem, mata de brejo, junto ao Córrego Vargem Limpa (Paliteiro), 22²0'29'S, 4900'90'W, 30-III-2006, J. Prado et al. 1643 (SP).

Distribuição geográfica geral: Equador, Peru e Brasil (MG, SP).

Os espécimes de Thelypteris biformata encontrados apresentaram lâmina adaxialmente com tricomas adpressos entre as nervuras e pinas proximais com pequenos aeróforos, o que pode dificultar a identi- ficação desta espécie baseada no trabalho de Smith (1992), onde essas características são mencionadas para Thelypteris lugubriformis (Rosenst.) R. Tryon, que não ocorre no país. Essa compreende a primeira citação de T. biformata para o Estado de São Paulo. A espécie pode ser facilmente reconhecida na área do JBMB pelas gemas presentes na axila das pinas distais e pelo indumento do pecíolo composto por tricomas estrelados. Foi encontrada crescendo em ambientes paludosos e sombreados.

Thelypteris conspersa (Schrad.) A.R. Sm., Univ. Calif. Publ. Bot. 59: 60. 1971 三 Nephrodium conspersum Schrad., Gött. Gel. Anz. 869. 1824. Lectótipo: designado por Smith, Univ. Calif. Publ. Bot. 59: 60. 1971: BRASIL. Próximo do Espírito Santo, Barra de Fucú, Wied-Neuwied s.n. (BR, n.v.; foto UC, n.v.; isolectótipo BR, L, n.v.).

Plantas terrestres. Caule curto-reptante, revestido no ápice por escamas linear-lanceoladas, castanhoescuras, pubescentes nas superfícies e margens. Frondes monomorfas 0,54-1,56 m compr.; pecíolo castanho a pardo, ca. $21-50 \times 0,2-0,4 \mathrm{~cm}$, base com escamas iguais às do rizoma; lâmina 1-pinadopinatífida, cartácea, 3-5 pares de pinas proximais gradualmente reduzidas, a maior ca. $10 \times 1,5 \mathrm{~cm}$, a menor ca. 2,5 $\times 0,9 \mathrm{~cm}$, ápice gradualmente reduzido; raque densamente pubescente em ambas as faces, tricomas aciculares, hialinos, ca. 1-2 mm compr.; pinas 26-36 pares, 26-2,5 × 0,9-2 cm, linear-lanceoladas, pinatífidas, ápice agudo, base truncada, sésseis, perpendiculares a ascendentes, par de pinas proximais deflexas; segmentos 0,5-1 ×0,1-0,3 cm, arqueados, ápice agudo a arredondado, margens inteiras; aeróforos ausentes; gemas ausentes; venação aberta, 8-9 pares de nervuras por segmento, com nervuras proximais de segmentos adjacentes unindo-se no sinus; indumento abaxialmente de tricomas aciculares, ca. $0,8 \mathrm{~mm}$ compr., moderados a densos, nas costas, nervuras e tecido laminar, também com tricomas glandulares amarelados, curto-pedicelados, adaxialmente com tricomas aciculares menores, ca. $0,5 \mathrm{~mm}$ compr., densos, nas costas, nervuras e tecido laminar e com tricomas glandulares pouco freqüentes nas cóstulas e nervuras. Soros arredondados, medianos; indúsio densamente pubescente; esporângios com tricomas glandulares no pedicelo.

Material examinado: próximo ao Córrego Vargem Limpa, 10-III-2004, G.A. Nóbrega et al. 51 (UNBA); à direita do Córrego Vargem Limpa, 17-V-2004, 
G.A. Nóbrega \& M. Andrade 68 (UNBA); mata de brejo junto ao Córrego Vargem Limpa (Paliteiro), 22020'29"S, 4900'90"W, 30-III-2006, J. Prado et al. 1635 (SP).

Distribuição geográfica: Hispaniola, Panamá, Venezuela, Colômbia, Peru, Bolívia, norte da Argentina, Paraguai, Uruguai e Brasil (BA, GO, DF, MT, MS, MG, RJ, SP, PR, SC, RS).

Esta espécie pode ser caracterizada na área estudada por apresentar pinas sésseis, nervuras proximais de segmentos adjacentes unidas no sinus e raque densamente pubescente em ambas as faces. No JBMB cresce entre gramíneas na área de campo, próxima ao Córrego Vargem Limpa.

Thelypteris eriosora (Fée) Ponce, Novon 8(3): 275. $1998 \equiv$ Aspidium eriosorum Fée, Crypt. Vasc. Brés. II: 73, tab. 101. 1873. Síntipos: BRASIL. RIO DE

JaneIRo: s.d., A. Glaziou 5264, 5265 (P?, n.v.). Figura 7 A-C

Plantas terrestres. Caule longo-reptante, com escamas pilosas, castanho-escuras, deltóides a lanceoladas, ca. $2 \mathrm{~mm}$ compr. Frondes $38-67 \mathrm{~cm}$ compr., distantes entre si; pecíolo estramíneo a castanho-claro, 13-14 cm compr., com escamas na base, semelhantes as do caule; lâmina lanceolada a oblongo-lanceolada, cartácea a subcoriácea, pilosa em ambas as faces, com 3-7 pares de pinas proximais abruptamente reduzidas; raque estramínea, pilosa em ambas as faces; pinas sésseis a curto-pecioluladas, lanceoladas a oblongolanceoladas, as medianas com ca. 5-8 × 0,9-1,5 cm, pinas proximais reduzidas hastadas, ca. $2-5 \times 1 \mathrm{~mm}$; costas pilosas em ambas as faces; segmentos oblongos, 4-8 × 1,5-2 mm; aeróforos presentes; venação aberta, 6-10 pares de nervuras por segmento, com nervuras proximais de segmentos adjacentes unindo-se à margem acima do sinus; indumento de tricomas setiformes eretos, nas margens, nervuras e lâmina foliar, moderados na superfície abaxial e esparsos adaxialmente, costa e raque adaxialmente com tricomas setiformes arqueados, densos e abaxialmente com tricomas setiformes eretos. Soros não vistos.

Material examinado: próximo à nascente do córrego Vargem Limpa, 22-XII-2005, G.A. Nóbrega \& M. Andrade 120 (SP).

Distribuição geográfica: endêmica do Brasil (RJ, SP).

A espécie não foi encontrada fértil, porém de acordo com Salino \& Semir (2004a) os soros são submarginais e arredondados, protegidos por um fascículo de tricomas setiformes e os esporângios são glabros. Thelypteris eriosora pode ser reconhecida pelo caule longo-reptante, pelo indumento composto apenas de tricomas setiformes e pelas pinas proximais abruptamente reduzidas. Esta espécie foi citada por Salino \& Semir (2004a), no Estado de São Paulo, apenas para Campos do Jordão, sendo este o primeiro registro para a região central do Estado. Foi encontrada em área de campo, com solo úmido, crescendo junto às gramíneas, próximo do Córrego Vargem Limpa.

Thelypteris heineri (C. Chr.) C.F. Reed, Phytologia 17(4): 282. 1968 = Doryopteris heineri C. Chr., Fedde Repert. 6: 380. 1909. Tipo: BRASIL. São Paulo: Campinas, 9-IX-1905, Heiner 540 (holótipo S, n.v.; isótipos S, BM, n.v.).

Figura 7 D-E

Plantas terrestres. Caule ereto, com escamas lanceoladas, ca. 3-7 mm compr., pubescentes, tricomas setiformes, sobre as superfícies e margens das escamas, ca. 0,5 $\mathrm{mm}$ compr. Frondes monomorfas, 86-88 cm compr.; pecíolo pardo-esverdeado, ca. 12-14 $\times 0,2 \mathrm{~cm}$, com tricomas setiformes, alvos, diminutos, ca. 0,1-0,5 mm compr. e tricomas uncinados, ca. 0,5-1 mm compr., base escurecida com escamas semelhantes às do rizoma; lâmina de contorno elíptico, 1-pinada-pinatissecta, cartácea, com 4-7 pares de pinas proximais abruptamente reduzidas; raque pilosa, tricomas setiformes, moderados a densos, pardos a castanhos, ca. 0,5-1 mm compr.; pinas oblongo-lanceoladas, ápice acuminado, ca. $6,5-8,5 \times 1-2 \mathrm{~cm}$, sésseis ou curto-pecioluladas, peciólulo ca. 0,5-1 mm compr., 2-4 pares de pinas proximais, auriculiformes ou vestigiais; costas semelhantes à raque; segmentos oblongos, levemente arqueados, ca. 0,7-1 cm compr., 1-3 mm larg., ápice obtuso, margens inteiras; aeróforos presentes; gemas ausentes; venação aberta, 10-13 pares de nervuras por segmento, com nervuras proximais de segmentos adjacentes unindo-se à margem acima do sinus; indumento de tricomas setiformes, ca. 0,1-0,5 mm compr., sobre as nervuras, cóstulas, margens e tecido laminar. Soros arredondados, submarginais, indúsio ausente; esporângios setosos, com ao menos um tricoma presente na cápsula.

Material examinado: mata de brejo (Paliteiro), 26-VI-2004, G.A. Nóbrega \& M. Andrade 82 (SP).

Distribuição geográfica: endêmica do Brasil (GO, DF, MG, SP). 


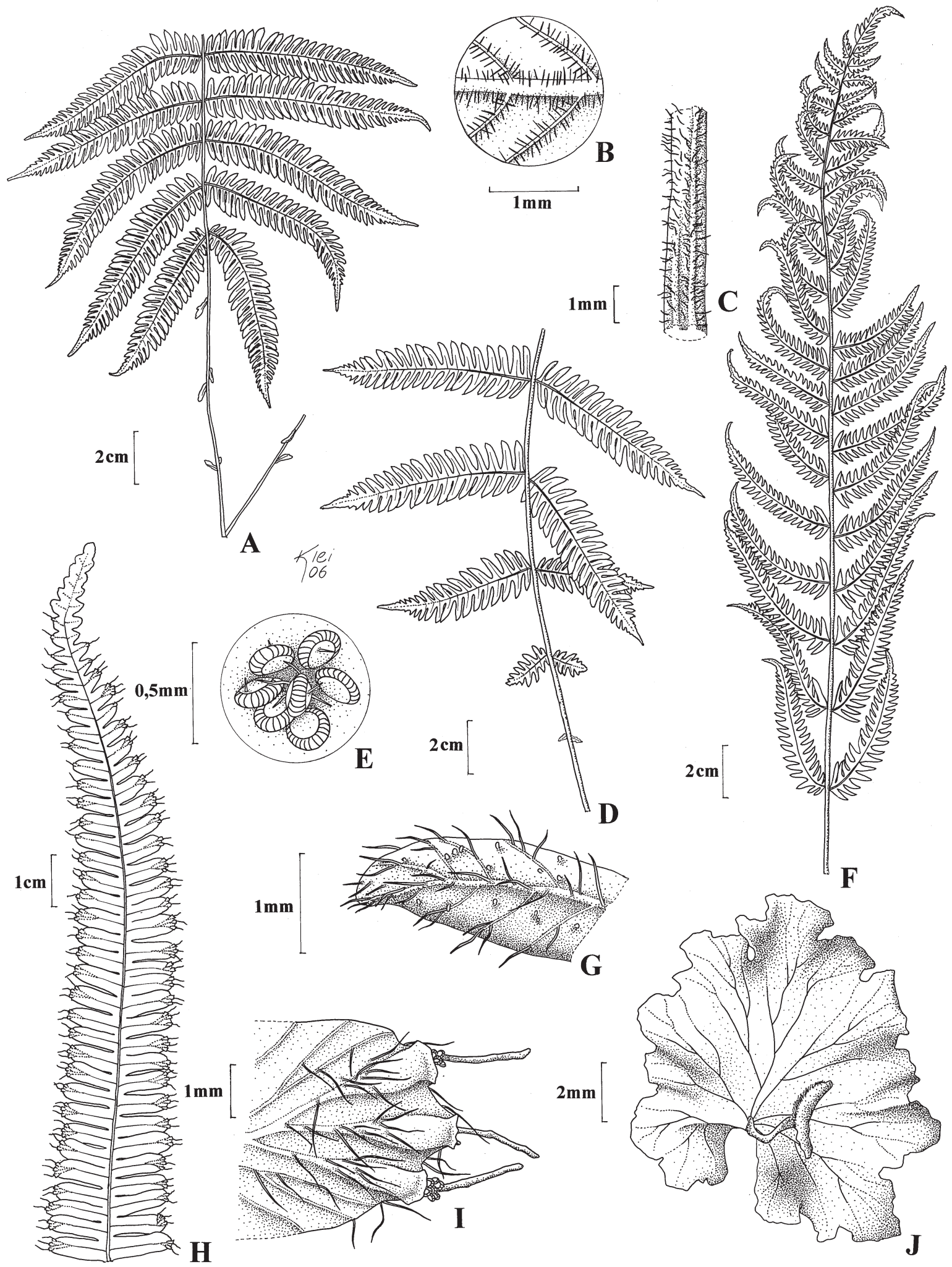

Figura 7. A-C. Thelypteris eriosora. A. Porção proximal de uma fronde estéril. B. Detalhe dos tricomas setiformes eretos, sobre as nervuras da lâmina foliar. C. Detalhe da face adaxial da raque, mostrando tricomas setiformes. D-E. Thelypteris heineri. D. Porção proximal de uma fronde fértil. E. Detalhe dos esporângios setosos. F-G. Thelypteirs mosenii. F. Parte de uma fronde estéril. G. Detalhe dos tricomas tectores e glandulares da face adaxial da lâmina. H-I. Trichomanes cristatum. H. Porção distal de uma pina fértil. I. Detalhe do indúsio. J. Trichomanes hymenoides. Fronde estéril. 
Pode ser caracterizada pelos tricomas presentes na cápsula do esporângio, aeróforos na base das pinas, tricomas uncinados no pecíolo e ausência de tricomas glandulares. Foi encontrada na Floresta Estacional Semidecidual Aluvial (mata de brejo), em local sombreado.

Thelypteris hispidula (Decne.) C.F. Reed, Phytologia 17: 283. 1968 = Aspidium hispidulum Decne., Nouv. Ann. Mus. Hist. Nat. 3: 346. 1834. Tipo: TIMOR. Sem localidade, s.d, Guichenot s.n. (holótipo P, n.v.).

Plantas terrestres. Caule curto-reptante, ápice com escamas castanho-escuras, linear-lanceoladas, pubescentes nas superfícies e margens. Frondes monomorfas, 58-68 cm compr.; pecíolo 32-23 ×0,2-0,3 $\mathrm{cm}$, estramíneo, porção basal com escamas iguais às do rizoma; lâmina 1-pinado-pinatífida, cartácea, ápice gradualmente reduzido, 1-3 pares de pinas proximais levemente a muito reduzidas, a menor com ca. $3 \mathrm{~cm}$ compr.; raque pubescente abaxialmente, tricomas 0,5-1 mm compr.; pinas 13-14 pares, 3-8 × 0,8-1,7 $\mathrm{cm}$, sésseis, perpendiculares a ascendentes, linearlanceoladas, ápice agudo, base truncada; segmentos 5-8 $\times 2-4 \mathrm{~mm}$, levemente arqueados, ápices arredondados, margens inteiras; aeróforos ausentes; gemas ausentes; venação aberta, 5-7 pares de nervuras por segmento, com nervuras proximais de segmentos adjacentes unindo-se abaixo do sinus a uma nervura excurrente com 2-3 mm compr. que se une ao sinus; indumento abaxialmente de tricomas aciculares, moderados a densos, 0,4-0,5 mm compr., nas costas, nervuras e tecido laminar, adaxialmente com numerosos tricomas aciculares, menores, 0,2-0,4 mm compr., nas cóstulas, nervuras e tecido laminar. Soros arredondados, medianos; indúsios pubescentes; esporângios com tricomas glandulares no pedicelo.

Material examinado: entrada à esquerda do córrego, embaixo de um limoeiro, 10-III-2004, G.A. Nóbrega et al. 50 (UNBA, SP); borda do Cerrado, 10-III-2004, G.A. Nóbrega et al. 60 (UNBA); Reserva Legal da Unesp, mata paludosa, 24-V-2006, M. Carboni et al. 408 (UNBA, SP).

Distribuição geográfica: sudeste dos Estados Unidos da América, Antilhas, México até o Panamá, Colômbia até Guiana e Bolívia, norte da Argentina, Brasil (AP, AM, PA, MA, PE, BA, MT, GO, DF, BA, MG, ES, RJ, $\mathrm{SP}, \mathrm{PR}, \mathrm{SC}, \mathrm{RS}$ ). Também ocorre na África tropical e subtropical e Ásia (Smith 1992).
Esta espécie pode ser facilmente confundida com Thelypteris dentata (Forssk.), porém Smith (1992) separa as duas pelo tamanho dos tricomas presentes na costa e pela cor do pecíolo e raque. Em $T$. dentata os tricomas presentes na superfície abaxial da costa são pequenos e uniformes, com ca. 0,1-0,2 mm compr. e o pecíolo e a raque são castanhos, enquanto $T$. hispidula apresenta tricomas maiores que $0,3 \mathrm{~mm}$ compr., com muitos excedendo $0,5 \mathrm{~mm}$, e pecíolo e raque estramíneos. Pode ser encontrada em área aberta, localizada do lado esquerdo do Córrego Vargem Limpa e na borda da Savana Florestada (Cerradão).

Thelypteris interrupta (Willd.) K. Iwatsuki, Jap. J. Bot. 38: 314. 1963 = Pteris interrupta Willd., Phytogr. 13, t. 10, fig. 1. 1794. Tipo: Sul da ÍNDIA, sem localidade definida, s.d., Klein s.n. (holótipo B, Herb. Willd. 19770; microficha UC, n.v.).

Plantas terrestres. Caule longo-reptante, 3-4 mm diâm., castanho-escuro, com escamas esparsas, linearlanceoladas, castanho-escuras. Frondes monomorfas $63-120 \mathrm{~cm}$ compr.; pecíolo $28-54 \times 0,2-0,4 \mathrm{~cm}$, pardo, desprovido de escamas na base; lâmina cartácea a subcoriácea, 1-pinado-pinatífida a crenada, pinas proximais maiores ou do mesmo tamanho das medianas; raque com escamas oblongo-lanceoladas, 1-2 mm compr., margens pilosas, adaxialmente com tricomas aciculares, 0,1-0,3 mm compr.; pinas 6-10 $\times$ 0,7-1,2 cm, curto-pecioluladas, peciólulo 0,5-1,5 $\mathrm{mm}$ compr., pinatífidas; pina terminal conforme; segmentos 2-5 mm larg., ápice arredondado, agudo ou obtuso; aeróforos ausentes; gemas ausentes; venação aberta, 5-7 pares de nervuras por segmento, com nervuras proximais de segmentos adjacentes, unindose a uma nervura excurrente, com 2-2,5 mm compr., que se dirige ao sinus; indumento abaxialmente de escamas deltóides a lanceoladas 1-1,5 mm compr., nas costas e tricomas aciculares ca. $0,4 \mathrm{~mm}$ compr. na margem da lâmina, adaxialmente com tricomas esparsos 0,1-0,5 mm compr., nas costas e nervuras. Soros arredondados supramedianos, freqüentemente confluindo na maturidade; indúsios glabros ou com tricomas nas margens; esporângios com tricomas glandulares presentes no pedicelo.

Material examinado: área de brejo, "Paliteiro", 30-I-2004, G.A. Nóbrega et al. 24 (UNBA); mata de brejo junto ao Córrego Vargem Limpa "Paliteiro", 22 20'29"S, 4900'90"W, 30-III-2006, J. Prado et al. 1634 (SP). 
Distribuição geográfica: Estados Unidos da América (Flórida), Antilhas, América Central, Colômbia, Venezuela, Guiana, Suriname, Guiana Francesa, norte da Argentina, Paraguai, Brasil (AM, AP, PA, MA, CE, PB, PE, AL, BA, MT, MS, TO, GO, DF, MG, ES, RJ, $\mathrm{SP}, \mathrm{PR}, \mathrm{SC}, \mathrm{RS}$ ). Também ocorre na África tropical e subtropical e Ásia (Smith 1992).

Esta espécie pode ser caracterizada pelas pinas com margens crenuladas, curto-pecioluladas, com nervuras proximais de segmentos adjacentes unindose abaixo do sinus a uma nervura excurrente e pela ausência de escamas na base do pecíolo. No JBMB, pode ser facilmente encontrada na área de brejo, inclusive em áreas dominadas por taboa.

Thelypteris longifolia (Desv.) R.M. Tryon, Rhodora 69: 777. $1967 \equiv$ Meniscium longifolium Desv., Mem. Soc. Linn. Paris, 6: 223. 1827. Tipo: VENEZUELA. Sucre: s.d., A.V. Humboldt s.n. (holótipo B, n.v.).

Plantas terrestres. Caule curto-reptante a ascendente, com escamas na porção apical, ovais a deltóides, castanho-escuras, ca. 2-3 mm compr., pilosas nas margens e superfícies. Frondes 1,95-2,97 m compr., monomorfas a levemente dimorfas; pecíolo ca. 1,3-1,5 m compr., amarelo-esverdeado, base escura, com escamas oblongo-lanceoladas a lanceoladas, castanhas, ca. 3-6 mm compr., pilosas nas margens e superfícies, porção mediana e apical com tricomas esparsos, aciculares, alvos, diminutos, ca. 0,2-0,5 mm; lâmina 1-pinada, lanceolada, cartácea, com ca. 11-13 pares de pinas laterais, pina terminal conforme, pinas proximais maiores ou do mesmo tamanho das medianas; raque com tricomas esparsos a moderados, aciculares, alvos a castanho-claros, ca. 0,5 mm compr.; pinas 21-31 × 3-4 cm, oblongolanceoladas, base cuneada, margem subinteira a crenulada, ápice acuminado, peciólulo curto ca. $1 \mathrm{~mm}$ compr.; costas com tricomas esparsos a moderados similares a raque; aeróforos ausentes; gemas ausentes; venação areolada (venação meniscióide), nervuras principais laterais retas, partindo da costa para a margem, distantes ca. $3 \mathrm{~mm}$, nervuras secundárias entre as principais laterais, ca. 17-18 pares, levemente arqueadas ou subsinuosas, formando um ângulo obtuso nas folhas férteis e um ângulo agudo nas estéreis, com uma nervura excurrente livre inclusa nas aréolas, partindo do vértice dos ângulos; indumento abaxial de tricomas aciculares ou setiformes, castanhoclaros a alvos, ca. 0,2-0,5 mm compr., nas nervuras, costa e tecido laminar, adaxialmente com tricomas apenas ao longo da costa. Soros oblongos a lineares, ligeiramente arqueados sobre o cruzamento das nervuras secundárias, não confluentes na maturidade; indúsio ausente; esporângios com tricomas diminutos, menores que $0,5 \mathrm{~mm}$ compr., no pedicelo.

Material examinado: após a bomba d'água dos posseiros, 14-IV-2005, G.A. Nóbrega \& M. Andrade 94 (UNBA); mata de brejo junto ao Córrego Vargem Limpa (Paliteiro), 22²0'29”'S, 4900'90”W, 30-III-2006, J. Prado et al. 1644 (SP).

Distribuição geográfica: Venezuela, Colômbia, Equador, Bolívia e Brasil (AM, GO, DF, MT, MS, MG, ES, RJ, SP, PR, SC).

De acordo com Smith (1992), Thelypteris longifolia está intimamente relacionada a $T$. arborescens (Willd.) Morton e as diferenças entre as duas espécies poderiam ser desconsideradas. Entretanto, Maxon \& Morton (1938 apud Smith 1992) distingüem as duas espécies, sendo que $T$. longifolia possui pinas com base cuneada, longo-pecioluladas e tricomas menores e menos densos quando comparados a $T$. arborescens. Thelypteris longifolia ocorre na Floresta Estacional Semidecidual Aluvial (mata de brejo), em local sombreado.

Thelypteris mosenii (C. Chr.) C.F. Reed, Phytologia 17: 294. $1968 \equiv$ Dryopteris mosenii C. Chr., Kongel. Danske Vidensk. Selsk. Skr., Naturvidensk. Math. Afd., ser. 7, 4: 300, fig. 27. 1907. Tipo: BRASIL. Minas Gerais: Rio Capivary, s.d, Mosén 2161 (holótipo S, n.v.).

\section{Figura 7 F-G}

Plantas terrestres. Caule curto-reptante, ca. 5-7 mm diâm. revestido no ápice por escamas lanceoladas, castanhas, ca. $5 \mathrm{~mm}$ compr., pilosas, tricomas ca. 0,1 $\mathrm{mm}$ compr. Frondes monomorfas, 57-85 × 7-10 cm; pecíolo $28-36 \times 0,2-0,3 \mathrm{~cm}$, com escamas na porção basal semelhantes às do caule, piloso, tricomas alvos moderados a densos, 0,1-1 mm compr.; lâmina 27-45 cm compr., catácea a subcoriácea, 1-pinadopinatissecta, contorno elíptico, com 1-7 pares de pinas proximais abruptamente reduzidas; raque com tricomas setiformes ca. $1 \mathrm{~mm}$ compr., moderados abaxialmente e densos na superfície adaxial; pinas 20-24 pares, perpendiculares, sésseis, lanceoladas, 4-6 × 0,7-1 cm, com ápice acuminado e base truncada, com tricomas setiformes ca. $0,5 \mathrm{~mm}$ compr. no tecido laminar e ca. $1 \mathrm{~mm}$ compr. na costa, densos na superfície adaxial e moderados na superfície abaxial; 
segmentos ca. $1 \mathrm{~mm}$ larg., ápice agudo a levemente arredondado, margem pilosa, sinuosa, inteira, revoluta, cobrindo parcialmente os soros; aeróforos ausentes; gemas ausentes; venação aberta, 7-9 pares de nervuras por segmento, com nervuras proximais de segmentos adjacentes unindo-se à margem acima do sinus, às vezes as basiscópicas unindo-se à margem junto ao sinus; indumento de tricomas setiformes arqueados a eretos, presentes nas escamas, no pecíolo, na raque, e em ambas as superfícies da lâmina, com maior concentração na superfície adaxial da costa; tricomas glandulares capitados, curto-pedicelados, presentes em ambas as superfícies das pinas, no tecido lâminar, nervuras e margens. Soros medianos a supramedianos, arredondados; indúsio reniforme, com tricomas glandulares capitados; esporângios glabros.

Material examinado: abaixo dos fios da torre de alta tensão, próximo à área da Unesp, 4-III-2004, G.A. Nóbrega et al. 33 (SP, SI); idem, 4-III-2004, G.A. Nóbrega et al. 34 (SP, SI).

Distribuição geográfica: oeste do Paraguai e Brasil (GO, DF, SP).

A espécie pode ser reconhecida, na área estudada, pelas pinas proximais abruptamente reduzidas e pelos tricomas glandulares presentes em ambas as superfícies das pinas. Cresce em matas de galeria, cerrados e pastagens, em solos pantanosos (Ponce 1998). Foi encontrada em área de campo, em solo encharcado, próximo à área da Unesp, exposta ao Sol. O espécime encontrado apresentou uma grande variação no número de pares de pinas proximais abruptamente reduzidas (1-7).

Thelypteris opposita (Vahl) Ching, Bull. Fan. Mem. Inst. Biol., Bot. 10: 251. 1941 = Polypodium oppositum Vahl, Eclog. Amer. 3: 53. 1807. Tipo: MONTSERRAT. Sem localidade, s.d., Ryan s.n. (holótipo C?; isótipo BM, n.v.).

Plantas terrestres. Caule subereto a ereto, com escamas castanho-escuras, oval-lanceoladas, glabras, ca. $2 \times 1 \mathrm{~mm}$. Frondes monomorfas, fasciculadas, 1-1,25 m compr.; pecíolo pardo a castanho, 36-46 cm compr., com escamas glabras na base; lâmina de contorno elíptico, cartácea a subcoriácea, 8-18 pares de pinas proximais gradualmente reduzidas; raque parda, pilosa na superfície adaxial, tricomas setiformes 0,3-0,8 mm compr.; pinas sésseis de contorno deltóide a lanceolado, com extremidades enroladas, ca. 5-7 $\times 0,8-1,2 \mathrm{~cm}$, pinas proximais hastadas ou auriculiformes $0,4-2,5 \times 0,2-0,8 \mathrm{~cm}$; costas moderadas a esparsamente pilosas; segmentos ovais a deltóides, 2-3 mm larg., margens revolutas; aeróforos ausentes ou pouco desenvolvidos; gemas ausentes ou pouco desenvolvidas; venação aberta, 4-6 pares de nervuras por segmento, com nervuras proximais de segmentos adjacentes unindo-se à margem acima do sinus; indumento adaxial de tricomas setiformes esparsos, 2-5 mm compr., nas costas, abaxialmente com tricomas unicelulares, aciculares, esparsos 0,1-0,5 mm compr. e tricomas glandulares sésseis nas nervuras, costas, margens e tecido laminar. Soros circulares, medianos; indúsios reniformes, com tricomas glandulares; esporângios glabros.

Material examinado: próximo ao córrego, à esquerda, 10-III-2004, G.A. Nóbrega et al. 52 (UNBA); mata de brejo junto ao Córrego Vargem Limpa (Paliteiro), 22 20'29"S, 4900'90"W, 30-III-2006, J. Prado et al. 1636 (SP).

Distribuição geográfica: Porto Rico, Pequenas Antilhas, Costa Rica, Panamá, Colômbia, Venezuela, Equador, Peru, Bolívia e Brasil (RO, GO, DF, MT, MS, BA, MG, SP, PR, SC).

Pode ser reconhecida pela presença de tricomas unicelulares e tricomas glandulares sésseis, na superfície abaxial sobre a costa, nervuras e margens, e pela superfície adaxial glabra ou com escassos tricomas setiformes. Ocorre na Floresta Estacional Semidecidual Aluvial (mata de brejo), em local sombreado.

Thelypteris rivularioides (Fée) Abbiatti, Mus. La Plata, Secc. Bot. 9: 19. 1958 = Aspidium rivularioides Fée, Crypt. Vasc. Brés. 1: 145, tab. 50, fig.1. 1869. Tipo: BRASIL. Rio DE JANEIRO: s.d., Glaziou 2358 (isótipo C, n.v.).

Plantas terrestres. Caule longo-reptante, com escamas deltóides a lanceoladas, castanho-escuras 2-4 mm compr., com poucos tricomas nas margens. Frondes monomorfas, 0,98-1,00 m compr.; pecíolo pardo, 10-15 cm compr. e 1-2 mm diâm., com tricomas aciculares, pluricelulares, pardos a alvos, 0,5-1 mm compr., basalmente com escamas linear-lanceoladas 2-3 mm compr., castanho-escuras, pilosas nas margens e superfícies; lâmina de contorno elíptico, 1-pinado-pinatífida, cartácea a subcoriácea, com 4-6 pares de pinas proximais gradualmente reduzidas, distantes $5-7 \mathrm{~cm}$; raque com tricomas pluricelulares aciculares 0,5-1 mm compr.; pinas sésseis, deltóides 
a lanceoladas, ápice atenuado, 4-7 × 1-1,8 cm; costas similares à raque; segmentos lineares, $2-3 \mathrm{~mm}$ larg., margens inteiras; aeróforos ausentes; gemas ausentes; venação aberta, 6-8 pares de nervuras por segmento, com nervuras proximais de segmentos adjacentes unindo-se à margem acima do sinus; indumento de tricomas unicelulares uncinados, com até $0,5 \mathrm{~mm}$ compr., no tecido laminar e nas margens, às vezes com tricomas capitados pequenos, menores que 0,5 $\mathrm{mm}$ compr. entre as nervuras, superfície adaxial com tricomas unicelulares, aciculares ou setiformes, nas cóstulas e nervuras, superfície abaxial com tricomas pluricelulares, aciculares, sobre cóstulas e nervuras. Soros circulares, submedianos; indúsios reniformes com tricomas glandulares; esporângios glabros.

Material examinado: área de brejo, próximo à lagoa, 30-I-2004, G.A. Nóbrega et al. 17 (UNBA).

Distribuição geográfica: Paraguai, Argentina, Uruguai e Brasil (GO, DF, BA, MG, RJ, SP, PR, SC, RS).

Esta espécie pode ser distingüida pelo rizoma rasteiro com escamas deltóides a lanceoladas, castanhoescuras, pela mistura de tricomas pluricelulares e escamas na base escura do pecíolo, pelas pinas deltóides a lanceoladas gradualmente reduzidas para a base, pinas proximais remotas e pela presença de tricomas uncinulados na superfície abaxial dos segmentos. Estas características apresentam uma ampla variação quantitativa e diferentes combinações nos tipos de tricomas do indumento (Ponce 1995).

Foi encontrada na borda da Floresta Estacional Semidecidual Aluvial (mata de brejo), em local ensolarado.

Thelypteris serrata (Cav.) Alston, Kew Bull. 1932 : 309. 1932 = Meniscium serratum Cav., Descr. Pl.: 548. 1802. Tipo: CUBA. Havana: s.d., Guio s.n. (holótipo MA, n.v.).

Plantas terrestres. Caule longo-reptante a ascendentes. Frondes 1-1,2 m compr., subdimorfas, pinas férteis mais estreitas; pecíolo estramíneo, glabro ou glabrescente; lâmina 1-pinada, com ca. 14-16 pares de pinas laterais, gradualmente reduzidas em direção ao ápice, lanceoladas, pina terminal conforme, pinas proximais maiores ou do mesmo tamanho das medianas; raque com esparsos tricomas aciculares, alvos; pinas 10-14 × 1,5-3 cm, sésseis ou pecioluladas, peciólulo 1-7 mm compr., base arredondada ou truncada, margens serradas, ápice agudo; aeróforos ausentes; gemas ausentes; venação areolada (venação meniscióide), nervuras laterais principais retas, distantes 2-3 mm, nervuras secundárias, ca. 8-14 pares, retas nas folhas férteis e arqueadas ou subsinuosas nas estéreis, formando um ângulo obtuso nas folhas férteis e um ângulo agudo nas estéreis, com uma nervura excurrente livre inclusa nas aréolas, partindo do vértice dos ângulos; indumento abaxial de tricomas, curvados, esparsos a moderados, $0,1-0,5 \mathrm{~mm}$ compr., nas costas, nervuras e, menos freqüiente, no tecido laminar, adaxialmente glabro. Soros oblongos a lineares, retos e arqueados no cruzamento das nervuras, freqüentemente confluindo na maturidade; indúsio ausente; esporângios pedicelados, glabros.

Material examinado: abaixo dos fios da torre de alta tensão, divisa com área da Unesp, 4-III-2004, G.A. Nóbrega et al. 30 (UNBA).

Distribuição geográfica: Estados Unidos da América (Flórida), México até o Panamá, Antilhas, Colômbia, Venezuela, Guiana, Suriname, Guiana Francesa, Bolívia, Paraguai, norte da Argentina e Brasil (AM, AP, AC, PA, RO, GO, DF, MT, MS, MA, CE, PB, PE, BA, MG, ES, RJ, SP, PR, SC, RS).

As características dos esporângios (pedicelados glabros), do número de pares de nervuras secundárias por pina (8-14 pares), juntamente com a forma da margem da lâmina (serrada) caracterizam esta espécie na área do JBMB. Pode ser encontrada na Floresta Estacional Semidecidual Aluvial (mata de brejo) e na Savana Estacional Florestada (cerradão), crescendo a pleno sol.

Trichomanes L., Sp. Pl. 2: 1097. 1753. Tipo: Trichomanes scandens $\mathrm{L}$.

Plantas terrestres, rupícolas ou epífitas. Caule vertical ou horizontal, curto a longo-reptante e filamentoso, moderadamente massivo a delgado, esparsa a densamente revestido por tricomas rígidos. Frondes monomorfas ou dimorfas (a fértil mais ereta que a estéril e a lâmina menor), separadas ou próximas entre si; lâmina membranácea, com uma ou duas camadas de células em espessura, inteira a 5-pinada, subséssil a peciolada, glabra ou com tricomas principalmente na costa e margem; pinas anadrômicas, catadrômicas ou algumas vezes flabeladas; venação aberta ou areolada nas proximidades da margem da lâmina, falsas vênulas presentes em algumas espécies, paralelas ou perpendiculares às nervuras verdadeiras. Soros terminais sobre as nervuras com um receptáculo alongado, saliente ao indúsio, sem paráfises; indúsio 
tubular ou infundibuliforme, bilabiado; esporos clorofilados, triletes.

Segundo Mickel \& Smith (2004) Trichomanes é um gênero Pantropical com pouco mais de 300 espécies, das quais cerca de 100 são americanas. O gênero diferencia-se por apresentar a lâmina membranácea, geralmente composta por uma camada de células, pelo indúsio tubular ou cônico e pelos soros com receptáculo alongado.

\section{Chave para as espécies de Trichomanes}

1. Lâmina lobada ou pinatífida, oblonga a arredondada ou reniforme; indúsio infundibuliforme, bilabiado T. hymenoides

1. Lâmina pinatissecta, linear-lanceolada; indúsio tubular, não bilabiado T. cristatum

Trichomanes cristatum Kaulf., Enum. fil.: 265. 1824. Tipo: "Brasília", Santa Catarina: Chamisso s.n. (holótipo LE, n.v.).

Figura 7 H-I

Plantas terrestres. Caule prostado, curto-reptante, ca. 2-3 mm diâm., revestidos por tricomas ca. $3 \mathrm{~mm}$ compr., castanho-escuros, pluricelulares e tortuosos. Frondes monomorfas, $38-51 \times 2-3,5 \mathrm{~cm}$, eretas; pecíolo castanho-escuro, $5-10 \mathrm{~cm}$ compr., não alado, com tricomas na base, ca. 2-5 mm compr., castanhoescuros, aciculares, formados por 1-6 células, com a célula basal expandida; lâmina pinatissecta, linearlanceolada, com ápice longamente atenuado, parte mediana alargada e os segmentos basais reduzidos; raque sulcada adaxialmente, com tricomas semelhantes aos do pecíolo; segmentos 0,5-2,5 $\times 0,3-1,0 \mathrm{~cm}$, margem ondulado-crispada, costa, nervuras e margem com tricomas unicelulares, castanhos, ca. $1 \mathrm{~mm}$ compr., inseridos sobre uma célula basal mais curta que as demais; nervuras livres, falsas vênulas ausentes. Soros imersos no tecido da lâmina, delimitados por duas nervuras laterais; indúsio tubular, não bilabiado, monocromático, margem inteira e glabra.

Material examinado: área dos posseiros, brejo, 5-XI-2004, G.A. Nóbrega \& M. Andrade 90 (SP).

Distribuição geográfica: Venezuela, Colômbia, Equador, Bolívia, Peru, Paraguai, Argentina e Brasil (AM, MT, GO, DF, MG, SP, PR, SC).

Segundo Windisch (1992), esta espécie está amplamente distribuída na América do Sul, sendo encontrada como terrestre e às vezes como epífita, desde o nível do mar até $1.400 \mathrm{~m}$ de altitude (embora aparentemente seja menos freqüente acima de 1.000 $\mathrm{m})$, crescendo em florestas úmidas, locais sujeitos a inundação e ambientes paludosos. De acordo com a classificação proposta por Morton (1968), esta espécie pertence à seção Achomanes (tricomas da superfície inferior da lâmina simples sobre uma célula basal distinta) e pertence ao grupo composto por $T$. crispum L. e espécies afins. Caracteriza-se pelo caule prostrado, curto-reptante e pelos longos tricomas, adpressos na raque e pecíolo, formados por 1-6 células, com a célula basal expandida. Ocorre em ambientes paludosos, próximos da área dos posseiros, crescendo à sombra.

Trichomanes hymenoides Hedw., Fil. Gen. Sp. tab.

3. 1799. Lectótipo: designado por Wessels-Boer, 1962: Hedwig, Fil. Gen. Sp. tab. 3, fig. 3. 1799, provavelmente baseado em uma coleta de Swartz, da Jamaica.

Figura 7 J

Plantas epífitas. Caule longo-reptante, ca. 1 mm diâm., densamente revestido por tricomas castanho-escuros, ca. $0,5 \mathrm{~mm}$ compr. Frondes monomorfas, 0,7-1,4 × 1-1,1 cm; pecíolo castanho, 0,5-4,5 mm compr., aplanado, não alado, com tricomas semelhantes aos do caule pelo menos na base; lâmina membranácea, 6-9,5 mm compr., com forma variável, oblonga a arredondada, reniforme ou raramente oblongo-lanceolada, base freqüentemente cordada ou arredondada, margem mais ou menos lobada regularmente ou pinatífida, com tricomas negros, furcados, inclusos também nos sinus; costa glabra; nervuras livres, subflabeladas, com uma costa distinta e percurrente até o ápice e lados das nervuras, pinadamente ramificadas, com falsas vênulas distribuídas esparsamente na lâmina. Soros sobre o lobo apical, não imersos no tecido laminar; indúsio infundibuliforme, bilabiado, margem dos lábios negra, inteira e glabra.

Material examinado: área de brejo da Unesp, 21-VII-2005, G.A. Nóbrega \& M. Andrade 105 (SP); idem, 4-X-2005, G.A. Nóbrega \& M. Andrade 117 (SP).

Distribuição geográfica: México, Grandes e Pequenas Antilhas, Trinidad, Venezuela, Colômbia, Equador, Peru, Bolívia, Argentina, Paraguai, Uruguai e Brasil (RJ, SP, PR, SC, RS).

Trichomanes hymenoides é uma espécie da seção Didymoglossum muito relacionada a T. reptans $\mathrm{Sw}$., 
T. ovale (Fourn.) W. Boer e T. kraussii Hook. \& Grev. Porém, $T$. hymenoides apresenta somente tricomas furcados na margem da lâmina, enquanto as outras três espécies apresentam tricomas furcados e estrelados (Mickel \& Beitel 1988, Proctor 1989, Tryon \& Stolze 1989). Segundo Mickel \& Beitel (1988) Trichomanes hymenoides caracteriza-se pela presença de tricomas apenas furcados, pela nervura principal pinada a ligeiramente palmada e pelos segmentos revolutos justapostos. Cresce como epífita, em ambientes paludosos e na margem de córregos.

Dos táxons encontrados, 38 são terrestres; destes, dois possuem hábito arborescente e um trepador, 15 são epífitas, sendo três epífitas facultativas, 10 holoepífitas e duas hemiepífitas.

Das formações vegetais presentes no JBMB a que possui a maior diversidade de espécies é a Floresta Estacional Semidecidual Aluvial (mata de brejo) com 38 espécies, a Savana (Cerrado) possui nove espécies e a Floresta Estacional Semidecidual Submontana (mata estacional) apresenta apenas oito. Dezessete espécies foram encontradas nas bordas destas formações vegetais, sendo que 11 ocorrem na borda da mata de brejo, quatro na borda do Cerrado e cinco na borda da Mata Estacional.

As matas de brejo e os ambientes das bordas das florestas abrigam $66 \%$ das espécies registradas. Das 17 espécies ocorrentes nas bordas, nove foram encontradas exclusivamente neste ambiente, as outras oito ocorrem tanto nas bordas quanto no interior das matas. Assim, a ocorrência de várias espécies no JBMB pode ser atribuída à presença de Floresta Estacional Semidecidual Aluvial (mata de brejo).

Thelypteris foi o gênero mais bem representado na área do JBMB com 11 espécies, distribuídas em quatro subgêneros. Thelypteris biformata (subg. Goniopteris) compreende uma nova citação para o Estado de São Paulo, provavelmente devido à carência de trabalhos de levantamentos florísticos detalhados para o interior, visto que sua ocorrência não é rara. Thelypteris eriosora (subg. Amauropelta) está sendo aqui registrada pela primeira vez para uma região de baixa altitude, localizada numa porção central do Estado. Ponce (1998) e Salino \& Semir (2004b) haviam relatado esta espécie apenas para a região de Campos do Jordão, no Estado de São Paulo, e para a Serra do Itatiaia, no Rio de Janeiro, ocorrendo em altitudes superiores a 1.500 metros.

Polybotrya goyazensis também está sendo registrada pela primeira vez para o Estado de São
Paulo. De acordo com Moran (1987), que publicou a revisão do gênero Polybotrya, esta espécie ocorria apenas nos estados do Pará, Goiás, Mato Grosso e no Distrito Federal.

\section{Agradecimentos}

Agradecemos ao diretor do Jardim Botânico Municipal de Bauru, Luiz Carlos de Almeida Neto, por ter viabilizado este projeto. A primeira autora também é extremamente grata à $\operatorname{Prof}^{\mathrm{a}} \mathrm{Dr}^{\mathrm{a}}$ Anne Dokkerdal, da UNESP-Bauru por ter incentivado a realização deste trabalho desde o início, à $\mathrm{Dr}^{\mathrm{a}}$ Monica Ponce pela colaboração na identificação das espécies Thelypteris eriosora e T. mosenii e a CAPES pela bolsa concedida.

\section{Literatura citada}

Adans, C.D. 1995. Asplenium. In: R.C. Moran \& R. Riba (eds.). Psilotaceae a Salviniaceae. In: G. Davidse, M. Souza \& S. Knapp (eds.). Flora Mesoamericana. Universidad Nacional Autónoma de México, Ciudad de México, v. 1, pp. 290-291.

Barrington, D.S. 1978. A revision of the genus Trichipteris. Contributions from the Gray Herbarium of Harvard University 208: 3-93.

Boldrin, A.H.L. \& Prado, J. 2007. Pteridófitas terrestres e rupícolas do Forte dos Andradas, Guarujá, São Paulo, Brasil. Boletim de Botânica da Universidade de São Paulo 25: 1-69.

Colli, A.M.T., Souza, S.A. \& Silva, R.T. 2003. Pteridófitas do Parque Estadual de Porto Ferreira (SP), Brasil. Revista do Instituto Florestal 15: 29-35.

Comissão de Solo. 1960. Levantamento de reconhecimento de solos do Estado de São Paulo. Boletim n ${ }^{\circ} 12$. Serviço Nacional de Pesquisas Agronômicas, Rio de Janeiro.

Hauke, R.L. 1995 Equisetaceae. In: R.C. Moran \& R. Riba (eds.). Psilotaceae a Salviniaceae. In: G. Davidse, M. Souza \& S. Knapp (eds.). Flora Mesoamericana. Universidad Nacional Autónoma de México, Ciudad de México, v. 1, pp. 4.

Hirai, R.Y. \& Prado, J. 2000. Selaginellaceae Willk. no Estado de São Paulo, Brasil. Revista Brasileira de Botânica 23: 313-339.

Kramer, K.U. 1957. A revision of the genus Lindsaea in the New World. Acta Botanica Neerlandica 6: 97-290.

Koeppen, W. 1948. Climatologia. Con un studio de los climas de la tierra. Versión directa de Pedro Hendrichs Pérez. Fondo de Cultura Económica, Ciudad de México.

Lellinger, D.B. 1987. The disposition of Trichopteris (Cyatheaceae). American Fern Journal 77: 90-94. 
Lellinger, D.B. 1988. Some new species of Campyloneurum and a provisional key to the genus. American Fern Journal 78: 14-35.

Lellinger, D.B. \& Prado, J. 2001. The group of Adiantum gracile in Brazil and environs. American Fern Journal 91: 1-8.

Lorea-Hernández, F. 1995. Pleopeltis. In: R.C. Moran \& R. Riba (eds.). Psilotaceae a Salviniaceae. In: G. Davidse, M. Souza \& S. Knapp (eds.). Flora Mesoamericana. Universidad Nacional Autónoma de México, Ciudad de México, v. 1, pp. 346.

Mickel, J.T. 1962. A monographic study of the fern genus Anemia, subgenus Coptophyllum. Iowa State Journal of Science 36: 349-482.

Mickel, J.T. \& Beitel, J.M. 1988. Pteridophyte Flora of Oaxaca, México. Memoirs of the New York Botanical Garden 46: 1-568.

Mickel, J.T. \& Smith A.R. 2004. The pteridophytes of Mexico. Memoires of the New York Botanical Garden 88: $1-1070$

Moran, R.C. 1987. Monography of the Neotropical fern genus Polybotrya (Dryopteridaceae). Illinois Natural History Survey Bulletin 34: 1-138.

Moran, R.C. 1995a. Pityrogramma. In: R.C. Moran \& R. Riba (eds.). Psilotaceae a Salviniaceae. In: G. Davidse, M. Souza \& S. Knapp (eds.). Flora Mesoamericana. Universidad Nacional Autónoma de México, Ciudad de México, v. 1, pp. 137-140.

Moran, R.C. 1995b. Polybotrya. In: R.C. Moran \& R. Riba (eds.). Psilotaceae a Salviniaceae. In: G. Davidse, M. Souza \& S. Knapp (eds.). Flora Mesoamericana. Universidad Nacional Autónoma de Mexico, Ciudad de México, v. 1, pp. 216-217.

Moran, R.C. 1995c. Salpichlaena. In: R.C. Moran \& R. Riba (eds.). Psilotaceae a Salviniaceae. In: G. Davidse, M. Souza \& S. Knapp (eds.). Flora Mesoamericana. Universidad Nacional Autónoma de Mexico, Ciudad de México, v. 1, pp. 332.

Moran, R.C. \& Mickel J.T. 1995 Anemia. In: R.C. Moran \& R. Riba (eds.). Psilotaceae a Salviniaceae. In: G. Davidse, M. Souza \& S. Knapp (eds.). Flora Mesoamericana. Universidad Nacional Autónoma de México, Ciudad de México, v. 1, pp. 53.

Morton, C.V. 1968. The genera, subgenera and sections of the Hymenophyllaceae. Contributions from the United States National Herbarium 38: 153-214.

Morton, C.V.\& Lellinger, D.B. 1966. The polypodiaceae subfamily Asplenioidea in Venezuela. Memoirs of the New York Botanical Garden 15: 1-49.

Nauman C.E. 1995. Nephrolepis Schott. In: Moran, R.C. \& Riba, R. (eds.). Psilotaceae a Salviniaceae. In: Davidse, G., Sousa, M. \& Knapp, S (eds.). Flora Mesoamericana. Universidad Nacional Autónoma de México, Ciudad de México, v. 1, pp. 286-289.
Øllgaard, B. 1995. Lycopodiella. In: R.C. Moran \& R. Riba (eds.). Psilotaceae a Salviniaceae. In: G. Davidse, M. Souza \& S. Knapp (eds.). Flora Mesoamericana. Universidad Nacional Autónoma de México, Ciudad de México, v. 1, pp. 18.

Øllgaard, B. 2001. Schizaeaceae. In: G. Harling \& L. Anderson (eds.). Flora of Ecuador. University of Göteborg, Göteborg, v. 66, pp. 81-104.

Øllgaard, B. \& Windisch, P.G. 1987. Sinopse das licopodiáceas do Brasil. Bradea 5: 1-43.

Østergaard-Andersen, E. \& Øllgaard, B. 2001. Gleicheniaceae. In: G. Harling \& L. Andersson (eds.). Flora of Ecuador. University of Göteborg, Göteborg, v. 66, pp. 103-169.

Palacios-Rios, M. 1995. Osmunda. In: R.C. Moran \& R. Riba (eds.). Psilotaceae a Salviniaceae. In: G. Davidse, M. Souza \& S. Knapp (eds.). Flora Mesoamericana. Universidad Nacional Autónoma de México, Ciudad de México, v. 1, pp. 51-52

Paschoal, M.E.S. \& Corrêa, P.L. 1996. Pelas Trilhas do Jardim Botânico de Bauru. Boletim Cultural 24: 13-19.

Pichi Sermolli, R.E.G. 1996. Authors of scientific names in Pteridophyta. Royal Botanic Gardens, Kew.

Pinheiro, M.H.O., Monteiro, R. \& César, O. 2002. Levantamento fitossociológico da floresta estacional semidecidual do Jardim Botânico de Bauru, São Paulo. Naturalia 27: 145-164.

Ponce, M.M. 1995. Las espécies austrobrasileñas de Thelypteris subg. Amauropelta (Thelypteridaceae, Pteridofita). Darwiniana 33: 257-283.

Ponce, M.M. 1998. Novedades en Thelypteris subg. Amauropelta (Thelypteridaceae) de Brasil y Paraguay. Novon 8: 275-279.

Prado, J. 1998. Pteridófitas do Estado de São Paulo. In: C.E.M. Bicudo \& G.J. Shepherd (eds.). Fungos macroscópicos e plantas do Estado de São Paulo (Série Biodiversidade do Estado de São Paulo). FAPESP, São Paulo, v. 2, p. 49-61.

Prado, J. 2003. New species in Adiantum from Brazil. American Fern Journal 93:76-80.

Prado, J. 2004a. Criptógamos do Parque Estadual das Fontes do Ipiranga, São Paulo, SP. Pteridophyta: 17. Pteridaceae. Hoehnea 31: 39-49.

Prado, J. 2004b. Criptógamos do Parque Estadual das Fontes do Ipiranga, São Paulo, SP. Pteridophyta: chave para as famílias; 2. Blechnaceae. Hoehnea 31: 1-10.

Prado, J. 2004c. Criptógamos do Parque Estadual das Fontes do Ipiranga, São Paulo, SP. Pteridophyta: 8. Gleicheniaceae. Hoehnea 31: 33-37.

Prado, J. 2004d. Criptógamos do Parque Estadual das Fontes do Ipiranga, São Paulo, SP. Pteridophyta: 5. Dennstaedtiaceae. Hoehnea 31: 11-22. 
Prado, J. 2005. Flora da Reserva Ducke, Amazonas, Brasil: Pteridophyta - Davalliaceae. Rodriguésia 56: 38-42.

Prado, J. \& Labiak, P.H. 2003. Flora de Grão-Mogol, Minas Gerais: Pteridófitas. Boletim de Botânica da Universidade de São Paulo 21: 25-47.

Proctor, G.R. 1989. Ferns of Puerto Rico and the Virgin Islands. Memoirs of the New York Botanical Garden 53: 1-389.

Pryer, K.M., Schuettpelz, E., Wolf, P.G., Schneider, H., Smith, A.R. \& Cranfill, R. 2004. Phylogeny and evolution of ferns (Monilophytes) with a focus on the early leptosporangiate divergences. American Journal of Botany 91: 1582-1598.

Rodrigues, R.R. \& Leitão Filho, H. 2000. Matas ciliares: conservação e recuperação. EDUSP, São Paulo.

Salino, A. 1996. Levantamento das pteridófitas da Serra do Cuscuzeiro, Analândia, SP, Brasil. Revista Brasileira de Botânica 19: 173-178.

Salino, A. \& Semir, J. 2002. Thelypteridaceae (Polypodiophyta) do Estado de São Paulo: Macrothelypteris e Thelypteris subgêneros Cyclosorus e Steiropteris. Lundiana 3: 9-27.

Salino, A. \& Semir, J. 2004a. Thelypteris subg. Amauropelta (Kunze) A.R. Sm. (Thelypteridaceae - Pterophyta) no Estado de São Paulo, Brasil. Lundiana 5: 83-112.

Salino, A. \& Semir, J. 2004b. Thelypteris subg. Meniscium (Thelypteridaceae - Pterophyta) no Estado de São Paulo, Brasil. Revista Brasileira de Botânica 27: 103-114.

Silva, A.T. 1989. Pteridófitas. In: O. Fidalgo \& V.L.R. Bononi (coords.). Técnicas de coleta, preservação e herborização de material botânico. Manual no 4. 2 ed. Instituto de Botânica, São Paulo, pp. 32-34.

Simabukuro, E.A., Esteves, L.M. \& Felippe, G.M. 1994. Lista de Pteridófitas da Mata Ciliar da Reserva Biológica de Moji Guaçu, SP. Insula 23: 91-98.

Siqueira, C.R. \& Windisch, P.G. 1998. Pteridófitas da Região Noroeste do Estado de São Paulo, Brasil: Dennstaedtiaceae. Acta Botanica Brasilica 12: 357-365.

Smith, A.R. 1986. Revision of the neotropical fern genus Cyclodium. American Fern Journal 76: 56-98.
Smith, A.R. 1992. 16. Thelypteridaceae. In: R.M. Tryon \& R.G. Stolze , Pteridophyta of Peru. Part III. Fieldiana, Botany, new series 29: 1-80.

Smith, A.R. 1995. Blechnaceae. In: P.E. Berry, B.K. Holst \& K. Yatskievych (eds.). Pteridophytes, Spermatophytes: Acanthaceae-Araceae. In: J.A. Steyermark, P.E. Berry \& B.K. Holst (eds.), Flora of the Venezuelan Guayana, Timber Press, Portland, v. 2, pp. 23-29.

Smith, A.R., Pryer, K.M., Schuettpelz, E., Korall, P., Schneider, H. \& Wolf, P.G. 2006. A classification for extant ferns. Taxon 55: 705-731.

Smith, A.R., Kreier, H., Haufler, C.H., Ranker, A.T. \& Schneider, H. 2006. Serpocaulon (Polypodiaceae), a new genus segregated from Polypodium. Taxon 55: 919-930.

Sota, E.R. 1960. Polypodiaceae y Grammitidiaceae Argentinas. Opera Lilloana 5: 1-229.

Sota, E.R. 2003. Neuva combinación en Pleopeltis (Polypodiaceae). Hickenia 3: 195-197.

Tryon, R.M. 1941. Revision of the genus Pteridium. Rhodora 43: 1-31, 37-70.

Tryon, R.M. \& Stolze, R.G. 1989. Pteridophyta of Peru. Part I. 1. Ophioglossaceae - 12. Cyatheaceae. Fieldiana, Botany, new series 20: 1-145.

Tryon, R.M. \& Stolze, R.G. 1993. Pteridophyta of Peru. Part V. 18. Aspleniaceae - 21. Polypodiaceae. Fieldiana, Botany, new series. 32: 1-190.

Tryon, R.M. \& Tryon, A.F. 1982. Ferns and allied plants, with special reference to tropical America. SpringerVerlag, New York.

Veloso, H.P., Rangel Filho, A.L.R. \& Lima, J.C.A. 1991. Classificação da vegetação brasileira adaptada a um sistema universal. Fundação Instituto Brasileiro de Geografia e Estatística, Rio de Janeiro.

Windisch, P.G. 1990. Pteridófitas da região NorteOcidental do Estado de São Paulo. Universidade Estadual Paulista, São José do Rio Preto.

Windisch, P.G. 1992. Trichomanes crispum L. (Pteridophyta, Hymenophyllaceae) and allied species. Bradea 6: 78-117. 